\title{
THE ROLE OF SOIL IN THE EXTERNAL CORROSION OF CAST-IRON WATER MAINS IN TORONTO, CANADA
}

\author{
by
}

Garry Doyle

A thesis submitted in conformity with the requirements for the degree of Master of Applied Science Graduate Department of Civil Engineering University of Toronto

(C) Copyright by Garry Doyle, 2000 
National Library of Canada

Acquisitions and Bibliographic Services

395 Wellington Street Ottawa ON KIA ONA Canada
Bibliothèque nationale du Canada

Acquisitions et services bibliographiques

395. nue Wellington

Ottawa ON KIA ONSA

Canada
The author has granted a nonexclusive licence allowing the National Library of Canada to reproduce, loan, distribute or sell copies of this thesis in microform, paper or electronic formats.

The author retains ownership of the copyright in this thesis. Neither the thesis nor substantial extracts from it may be printed or otherwise reproduced without the author's permission.
L'auteur a accordé une licence non exclusive permettant à la Bibliothèque nationale du Canada de reproduire, prêter, distribuer ou vendre des copies de cette thèse sous la forme de microfiche/film, de reproduction sur papier ou sur format électronique.

L'auteur conserve la propriété du droit d'auteur qui protège cette thèse. $\mathrm{Ni}$ la thèse ni des extraits substantiels de celle-ci ne doivent être imprimés ou autrement reproduits sans son autorisation. 


\section{Abstract}

The Role of Soil in the External Corrosion of Cast-Iron Water Mains in Toronto, Canada

Master of Applied Science, 2000

Garry Doyle

Graduate Department of Civil Engineering

University of Toronto

External corrosion of a cast-iron water main is influenced by the soil which surrounds it. $A$ soil's "corrosiveness" is affected by factors such as resistivity, $\mathrm{pH}$ and sulphate reducing bacteria. This study collected water main and soil samples from locations across Toronto. Of the collected pipe samples $73 \%$ had experienced external corrosion; indicating that deterioration due to external corrosion is a concern. Using the measured soil properties, a linear regression analysis was able to explain $41 \%$ of the variance in the maximum external pitting rate. Looking at the effect of the soil properties individually the observed maximum external pitting rate was found to correlate best with soil resistivity. This thesis also found that there may be limitations to the practical application of the AWWA soil corrosiveness system. Finally, the use of GIS's in maintaining and rehabilitating water distribution systems is presented and a spatial analysis of the data is conducted. 


\section{Acknowledgements}

The Author would like to thank the City of Toronto, Canada for funding and supporting this project. Special thanks go to Robert Klimas of the City of Toronto for his assistance in providing information on the use of GIS by the City and data about the age of the pipe samples from Etobicoke. A number of people assisted in the preparation of this thesis. I would like to thank Professor Murray Grabinsky for his time and effort in supervising this project. I would also like to thank Professor Jeff Packer and Michael Seica for organizing this project with the City of Toronto and providing technical data on the pipe samples collected during the course of this research. 


\section{Table of Contents}

Abstract

Acknowledgements

1.0 introduction

2.0 Paper One - The Role of Soil in the External Corrosion of Cast-Iron Water Mains in. 3 Toronto, Canada

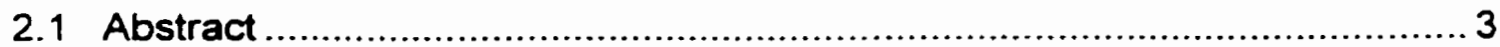

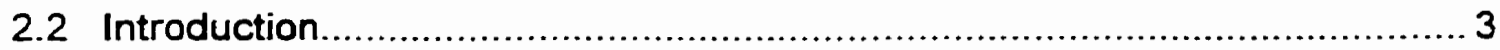

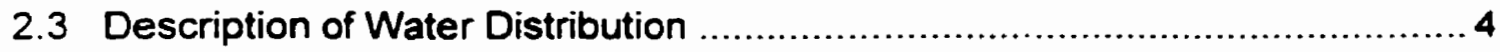

2.4 Mechanisms of Pipe Deterioration .................................................... 5

2.4.1 Internal Corrosion................................................................ 5

2.4.2 External Corrosion ............................................................. 5

2.4.2.1 Galvanic Corrosion Cells ...................................... 6

2.4.2.2 Electrolytic Corrosion Cells ........................................ 7

2.4.2.3 Bacterial Corrosion .............................................. 8

2.4.2.4 Acid Attack ........................................................ 8

2.4.2.5 Polarization......................................................... 9

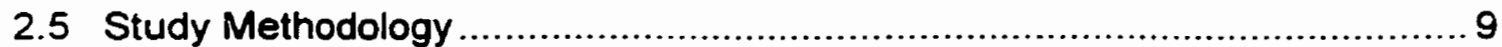

2.5.1 Sampling Technique ......................................................... 9

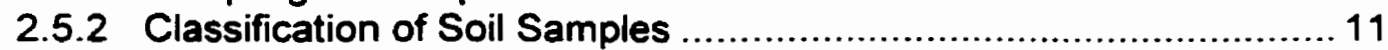

2.5.3 Soil Resistivity Test ........................................................... 11

2.5.4 Soil Sulphide Content Test.................................................. 11

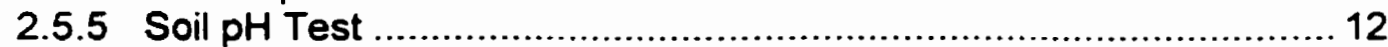

2.5.6 External Pitting Corrosion Measurements ............................... 12

2.6 Analysis/Discussion of Results .................................................. 13

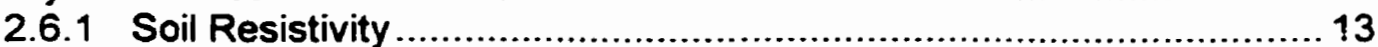

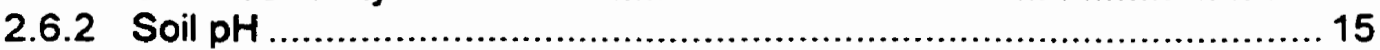

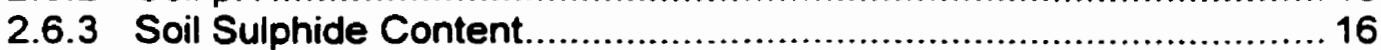

2.6.4 AWWA Soil Corrosiveness Rating............................................. 19

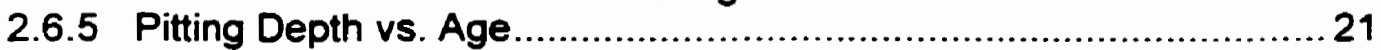

2.6.6 Correlating External Pitting Rate to Soil Properties ...................... 21

2.6.6.1 Soil Resistivity vs. External Pitting Rate ............... 23

2.6.6.2 Soil pH vs. External Pitting Rate......................... 24

2.6.6.3 Sulphide Content vs. External Pitting Rate ............ 24

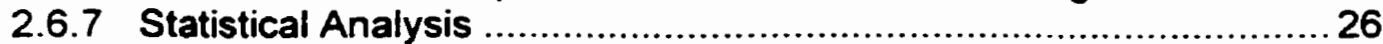

2.6.7.1 Correlation Between Soil Properties.................... 26

2.6.7.2 Linear Regression Model ................................ 27

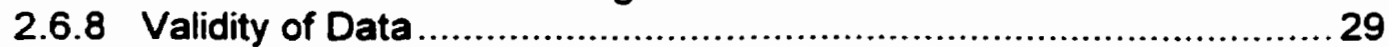

2.6.9 Preliminary Spatial Analysis ................................................. 29 


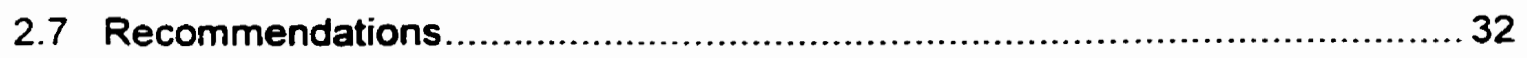

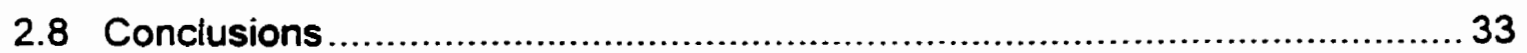

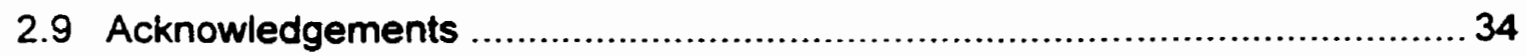

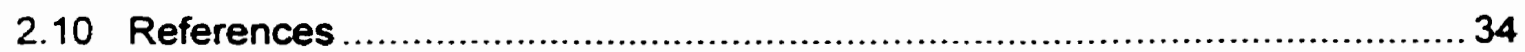

2.11 Appendix - Summary of Collected Data ......................................... 37

3.0 Paper Two - The Application of GIS to a Water Main Corrosion Study..................... 38

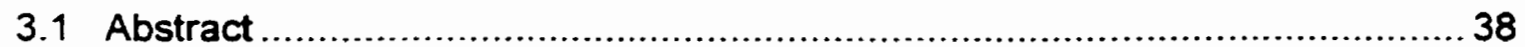

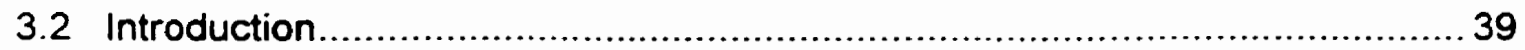

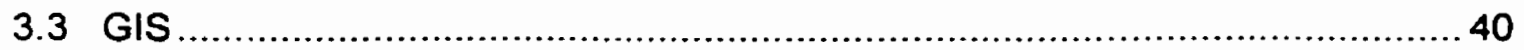

3.3.1 The Use of GIS by the City of Toronto................................40 40

3.4 Survey Results ....................................................................... 41

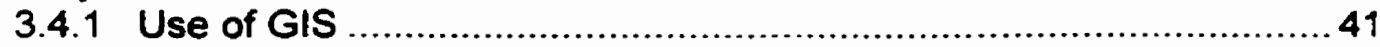

3.4.2 Length of Time Using GIS ......................................... 42

3.4.3 Detail of the Data Available Through the GIS .......................... 43

3.4.4 GIS and the Internet........................................................... 46

3.4.5 Advantages Found Using a GIS .......................................... 48

3.4.6 The Application of GIS's to Water Main Maintenance and ...............48 48 Rehabilitation

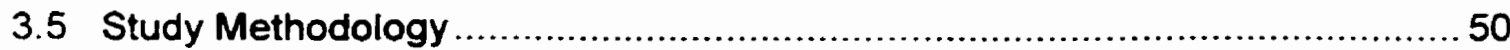

3.5.1 Classification of Soil Samples .............................................. 51

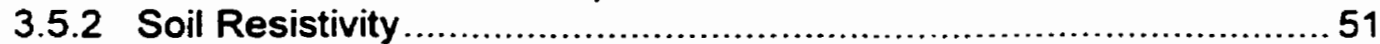

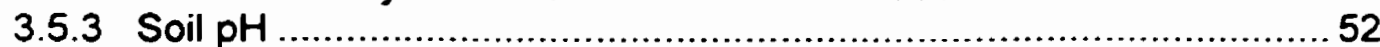

3.5.4 Soil Sulphide Content................................................... 52

3.6 GIS Description ........................................................................ 53

3.6.1 Layer 1 - Geocoded Centre-Line Street Map of........................... 53

Etobicoke and Toronto

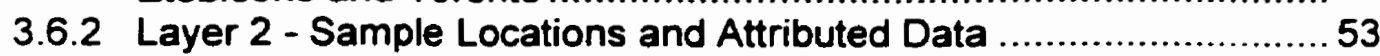

3.6.3 Layer 3 - Surface Soil Map of Toronto and Etobicoke .................. 53

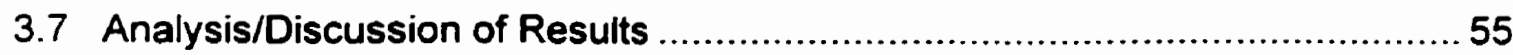

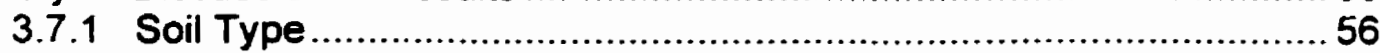

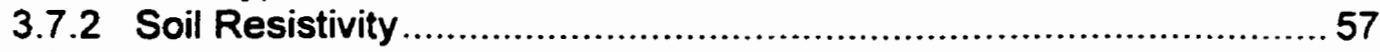

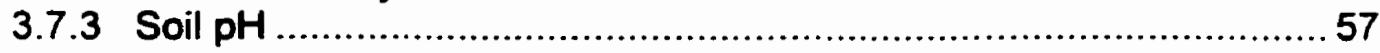

3.7.4 Soil Sulphide Content........................................................ 59

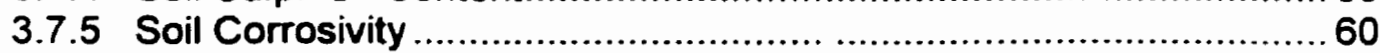

3.7.6 Maximum External Pitting Rates of Water Main Samples ...............60 60

3.7.7 Corrosion Index............................................................... 61 
3.8 Recommendations................................................................. 61

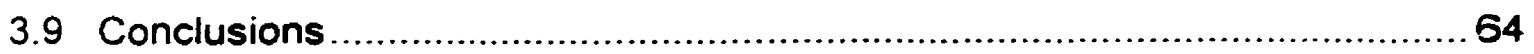

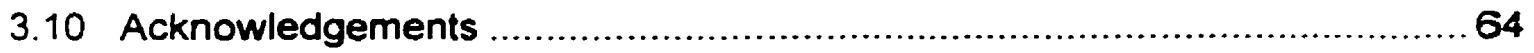

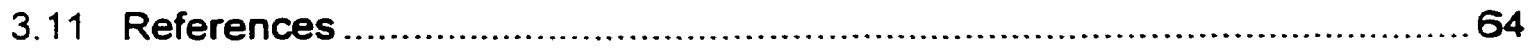

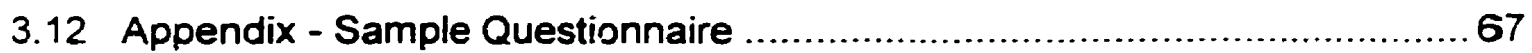

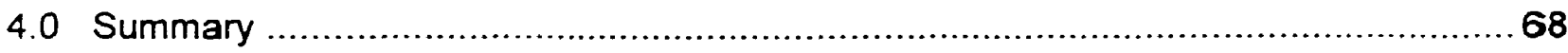

\section{List of Tables}

Table 2.1 - Soil Corrosiveness vs. Resistivity ............................................. 7

Table 2.2 - Summary of Data Collected ..................................................... 10

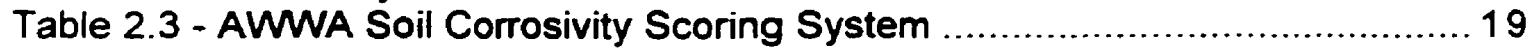

Table 2.4 - Results of the AWWA Scoring System .................................... 21

Table 2.5 - Correlation Coefficients for Maximum External Pitting Rates and Soil . 26 Properties

Table 3.1 - List of Cities Responding to Survey ........................................... 42

Table 3.2 - Cities Grouped by the Detail of the Data.................................... 44 Available Through Their GIS

\section{List of Figures}

Figure 2.1 - Histogram of Soil Resistivity ................................................. 14

Figure 2.2 - Resistivity Range by Soil Type ............................................. 14

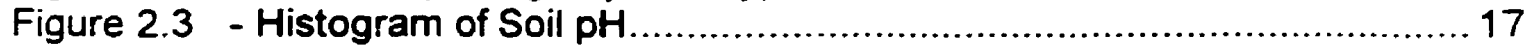

Figure 2.4 - pH Range by Soil Type ................................................... 17

Figure 2.5 - Histogram of Soil Sulphide Content ....................................... 18

Figure 2.6 - Range of Sulphide Content by Soil Type ............................... 18

Figure 2.7 - Maximum External Pitting Rate vs. AWWA Score ....................... 22

Figure 2.8 - Maximum External Pitting Depth vs. Age of Pipe .......................... 22

Figure 2.9 - Maximum External Pitting Rate vs. Soil Resistivity .......................... 24

Figure 2.10 - Maximum External Pitting Rate vs. Soil pH................................. 25

Figure 2.11 - Maximum External Pitting Rate vs. Sulphide Content of Soil ........... 25

Figure 2.12 - Predicted vs. Observed Maximum External Pitting Rates ................ 28

Figure 2.13 - Maximum External Pitting Rate Superimposed ............................. 31 onto the City Street Map

Figure 2.14 - Resistivity of Collected Soil Samples Superimposed ...................... 31 onto the City Street Map

Figure 3.1 - GIS Layer 1 - Geocoded Centre-line Street Map of Toronto ............ 54 and Etobicoke

Figure 3.2 - GIS Layer 2 - Sample locations and Attributed Data ...................... 54 (Superimposed on Layer 1)

Figure 3.3 - GIS Layer 3 - Surface Soil Map of Toronto and Etobicoke...............55 
Figure 3.4 - Soil Resistivity Referenced to Street Map .................................... 58

Figure 3.5 - Soil Resistivity Referenced to Surficial Soil Map ............................ 58

Figure 3.6 - pH Referenced to Street Map ................................................. 59

Figure 3.7 - Sulphide Distribution Referenced to Street Map ..........................62

Figure 3.8 - AWWA Score Referenced to Soil Map.......................................62

Figure 3.9 - Maximum External Pitting Rates Referenced to Street Map ............63

Figure 3.10 - Corrosion Index Referenced to Street Map.................................63

\section{List of Appendices}

Appendix A - Summary of Soil and Pipe Data 


\subsection{Introduction}

The City of Toronto maintains and operates a water distribution network consisting of over $5800 \mathrm{~km}$ of pipeline. The majority of the water mains are grey cast-iron and ductile cast-iron pipes. Some sections of the system located in the downtown core have been in service for over 100 years. As the distribution system ages there is increased concern that water main deterioration could be a major problem in the coming years. For this reason the City of Toronto contracted with the University of Toronto to undertake an investigation into the condition of the city's water mains.

Water main failures are commonly referred to as "breaks". This term actually encompasses a number of possible failure mechanisms. A water main may fail due to mechanical stresses placed on the pipe, corrosion of the pipeline or a combination of both.

Normally, a water main is strong enough to withstand pressures from water, freeze/thaw cycles, frost heave, surface loads and soil loads. Only when its structural integrity has been compromised by corrosion does it become more susceptible to failing. This is why understanding the causes of underground corrosion is important in understanding water main failures. Determining what causes the pipe to corrode makes it possible to locate potential problem areas in the city.

Soil plays an important role in the corrosion process. Soil properties such as resistivity, $\mathrm{pH}$ and the presence of sulphate reducing bacteria have been identified as influencing the rate and extent of external corrosion experienced by underground cast-iron pipelines. However, the real world effects of these soil factors on the external corrosion rate of water mains are not well understood. Previous investigations into water main corrosion have had mixed success in correlating the rate of external corrosion to specific soil properties (Gummow and Wakelin 1993; Jakobs and Hewes 1987; originally Weiss et al. 1985, referenced in O'Day 1989; Miller 1981). Also, as soil properties are highly variable from location to location it would be questionable to blindly apply other city's experiences to that of Toronto. For this reason it is valid for the City of Toronto to conduct its own investigation into the problem.

Understanding the causes of external corrosion is only half the solution. The other is knowing which areas of the city's distribution network are most at risk and being able to predict where future problems may arise. For this reason it was decided to input the data collected during the study into a Geographic Information System (GIS). A GIS allows data to 
be referenced to a geographic location. By performing a spatial analysis it can be seen whether water mains in a certain area of the city have experienced more external corrosion than other sections or if they are placed in soils with properties making them excessively "corrosive" towards cast-iron water mains. With a large enough data-set a GIS could be used to used plan and prioritize future water main replacement programs.

This thesis will look at the issues discussed above. The format of this thesis consists of a compilation of two papers. The first paper (to be submitted to the Journal of the Canadian Geotechnical Society) looks at the role soil has in the external corrosion of cast-iron water mains. It provides a detailed explanation of the mechanisms which cause water main deterioration and the effect soil properties have on the corrosion process. It then describes the methodology used during the City of Toronto study to collect and test the soil and pipe samples. Next, it presents an analysis of the collected data. Finally, the paper draws some conclusions about how the various soil properties are affecting the external corrosion rate of Toronto's water mains.

The second paper (to be submitted to the journal of the American Water Works Association) looks at the application of GIS to a water main corrosion study. It presents some examples of how other cities and utilities are using GIS's to manage their infrastructure and plan water main rehabilitation programs. It also looks at some of the emerging trends in how GIS's are being used to share information. Specifically, how organizations are taking advantage of the Internet to provide wider access (both to the public and their employees) to their GIS's. The paper then presents an overview of the City of Toronto water main investigation and briefly explains how the various soil properties influence the external corrosion rate and how this study tested for them. Finally, it describes the GIS created during this investigation and presents the results found when it was used to spatially analyze the collected data.

In the final section a summary of the two papers is provided. This section reiterates the conclusions drawn in the two papers. Some suggestions are made regarding future areas of research and how the data-set could be improved. Finally, this section also makes some suggestions about how future corrosion studies should be conducted. 


\subsection{Paper One}

\section{The Role of Soil in the External Corrosion of Cast-Iron Water Mains in Toronto, Canada}

\subsection{Abstract}

A major factor contributing to the deterioration of cast-iron water mains is external corrosion. External corrosion weakens the pipe wall increasing the risk of failure. External corrosion is a function of the interaction between the pipeline and the soil by which it is surrounded. A soil's "corrosiveness" towards cast-iron is affected by properties such as resistivity, pH and the presence of sulphate reducing bacteria. This study collected water main sections and accompanying soil samples from locations across Toronto. A linear regression analysis of the data is able to only explain $41 \%$ of the variance in the maximum external pitting rate. Looking at the effect of the soil properties individually it appears that the observed maximum external pitting rate correlates best with soil resistivity. It is also shown that there may be limitations to the practical application of the AWWA soil corrosiveness scoring system. A preliminary spatial analysis of the data indicates that water mains in the district of Etobicoke have had a higher rate of external corrosion than those in the district of Toronto. It is aiso found that there may be areas in the district of Etobicoke where bacterial influenced corrosion is a problem.

\subsection{Introduction}

As water distribution networks age, cities in North America are facing the prospect of increasing maintenance costs and the decision of whether to replace or repair their water mains. A study by the United States Erivironmental Protection Agency estimated that over the next 20 years, $\$ 138$ billion dollars (US) must be invested into water systems in the United States (Hertzler and Davies 1997). In Canada, the tragic events in Walkerton, Ontario have highlighted the need for safe and reliable water distribution networks and put political and public pressure on municipalities to ensure that their systems are safe and reliable (Baille 2000; Brennan 2000).

Recognizing that water main deterioration is potentially a major problem, the City of Toronto contracted with the University of Toronto to undertake an investigation into the condition of the city's water distribution network. The city hoped that through this project it would be better 
able to focus its rehabilitation efforts by having a more complete understanding of the causative factors behind water main deterioration.

The corrosion mechanisms which cause water mains to deteriorate have been well documented. It has been established that the "corrosiveness" of a soil is affected by properties such as soil type, $\mathrm{pH}$, resistivity and sulphate reducing bacteria (Romanoff 1964, O'Day 1989; Robinson 1993). However, the real world influence these soil properties have on cast-iron water main corrosion is not as well understood. Previous studies attempting to correlate the amount of external corrosion with specific soil properties have had mixed success (Gummow and Wakelin 1993; Jakobs and Hewes 1987; originally Weiss et al. 1985. referenced in O'Day 1989; Millet et al. 1981). Adding to the problem is that each city faces a unique set of conditions with respect to type and mix of pipe line materials, soil properties and other factors. This makes the application of "generic" rating systems to Toronto's distribution network questionable. For this reason it was necessary and valid for Toronto to conduct its own investigation.

This paper provides a review of the mechanisms which cause water main deterioration and the effect soil properties have on the corrosion process. The data gathered through the City of Toronto study is then presented and analyzed. Based on the available data some conclusions about the influence soil properties have on the corrosion of Toronto's water mains are drawn.

\subsection{Description of Water Distribution System}

The City of Toronto maintains and operates $5347 \mathrm{~km}$ of local water mains (average diameter of $150 \mathrm{~mm}-300 \mathrm{~mm}$ ) and $487 \mathrm{~km}$ of trunk water mains (Klimas, pers. comm. 2000). The majority of the network consists of grey cast-iron and ductile cast-iron pipes. The oldest parts of the system are located in the downtown core with pipe age decreasing towards the periphery of the city. Pipe samples encountered in this project ranged from 30 to 120 years old.

The surficial stratigraphy of Toronto was formed as a result of the last ice age. As such, the majority of the surficial soils in which the water distribution network is laid consist of clayeysilty tills formed by glaciers or sand and clay deposits created by extinct glacial lakes (such as Lake Iroquois and the Peel Ponds). As will be explained in this paper in detail, because of their properties (such as low resistivity) clays and silts have been found to be more corrosive 
towards cast-iron water mains than other soils (such as sands and gravels). Therefore, simply based on the pre-existing conditions the surficial stratigraphy of the Toronto area potentially puts the water distribution network at increased risk for deterioration. The research conducted during this study will begin to quantify that risk.

\subsection{Mechanisms of Pipe Deterioration}

Water main failures are commonly referred to as "breaks". This term actually encompasses a number of possible failure mechanisms. A water main may fail due to mechanical stresses placed on the pipe, corrosion of the pipeline or a combination of both.

Normally, a water main is strong enough to withstand pressures from water, freeze/thaw cycles, frost heave, surface loads and soil loads. Only when its structural integrity has been compromised by corrosion does it become more susceptible to failing. This is why understanding the causes of underground corrosion is important in understanding water main failures. Determining what causes the pipe to corrode makes it possible to locate potential problem areas in the city.

\subsubsection{Internal Corrosion}

The internal corrosion of water mains is a better understood phenomenon than external corrosion. Tools such as Baylis curves and Langelier's equation have been developed which can be used to determine whether water will be corrosive to a pipe.

Internal corrosion is controlled by the physical, chemical and biological properties of the water flowing through the pipeline. Factors such as water velocity, temperature, $\mathrm{pH}$ and alkalinity all affect the internal corrosion rate (Singley et al 1985). Internal corrosion is in no way influenced by soil properties.

\subsubsection{External Corrosion}

External water main corrosion is a function of the interaction between the pipeline and the soil by which it is surrounded. In theory, the method of corrosion follows a simple and well known electrochemical process but in reality the factors which can affect the pitting rate are complex and vary from case to case.

In general, the wide variety of conditions in which water mains are found leads to numerous possible corrosion mechanisms. The most dominating is electrochemical in nature and will be considered first. 
With this type of corrosion, metal loss occurs on the surface of cast-iron water mains at the anode due to an oxidation reaction. Iron atoms enter into solution generating electrons:

$$
\mathrm{Fe} \rightarrow \mathrm{Fe}^{2+}+2 \mathrm{e}^{-}
$$

Simultaneously, a spontaneous reduction reaction is occurring at the cathode. The reaction uses electrons generated at the anode in the reduction of oxygen or the reduction of hydrogen ions:

$$
\begin{aligned}
& \mathrm{O}_{2}+2 \mathrm{H}_{2} \mathrm{O}+4 \mathrm{e}^{-} \rightarrow 4 \mathrm{OH}^{-} \\
& 2 \mathrm{H}^{+}+2 \mathrm{e}^{-} \rightarrow \mathrm{H}_{2}
\end{aligned}
$$

Therefore, the overall reaction is:

$$
\mathrm{Fe}^{2+}+2 \mathrm{OH}^{-} \rightarrow \mathrm{Fe}(\mathrm{OH})_{2}
$$

This is the basic reaction responsible for electrochemica! corrosion. There are two types of corrosion cells which use this reaction. One is called a galvanic corrosion cell and the other an electrolytic corrosion cell. The two cells differ in how the driving force behind the electron flow is provided.

\subsubsection{Galvanic Corrosion Cells}

Galvanic corrosion cells are the most common cause of water main deterioration due to the variety of conditions which can initiate their formation. Galvanic corrosion cells differ from electrolytic cells in that the direct current flow, between the anode and the cathode, is generated within the cell itself as a result of the anode and cathode having different electromotive potentials.

A galvanic corrosion cell can be formed when metals with different electrical potentials are connected together. This difference creates a driving force which causes electron flow to occur thus creating a corrosion cell. Most bi-metallic corrosion cells are formed because of the lead or copper services connected to the water main. A study of water main breaks in Ontario municipalities (Gummow and Wakelin 1993) concluded that "the use of copper service piping is the primary reason for high water main corrosion rates, and hence, high water main failure rates". The corrosion rate is higher for copper-iron connections because the difference in electrical potential between the two metals is much greater than that for leadiron. 
Galvanic corrosion cells may also be established due to differences in the composition of the soil that the pipeline travels through. Differences in potential between the pipe and soil 1 and the pipe and soil 2 can cause a galvanic cell to be established. Some causes of dissimilar soil conditions are (Smith 1989):

- Low resistivity soil (anodic) - High resistivity soil

- Wet soil (anodic) - Dry soil

- Clay - Silt or sand

- Poorly aerated soil (anodic) - Well aerated soil (oxygen concentration cell)

- low pH (anodic) - High pH

This raises the possibility that fixing a water main break may cause additional corrosion problems. In the course of repairing the pipe the soil around the break is disturbed by digging and the native material is replaced by some specified fill. This may cause a new corrosion cell to form due to dissimilar soil conditions.

When corrosion is electrochemical in origin, soil resistivity plays a major factor in determining the corrosion rate. The lower the resistivity of the soil the higher the corrosion rate. Typically, because of the high ion content of their porewater, clays have the lowest resistivities while sands and gravels have the highest. The "natural" resistivity of a soil can be modified by the presence of additional ions in the porewater (for example from contamination by road salt). Table 2.1 (Robinson 1993) relates soil resistivity to corrosion potential. This table is not definitive for determining a soil's corrosiveness. Additional corrosion mechanisms (such as bacterial corrosion) can cause severe water main deterioration in soil which has a high resistivity.

Table 2.1 - Soil Corrosiveness vs. Resistivity

\begin{tabular}{c|c} 
Soil Resisitivity (ohm.cm) & Corrosion Potential \\
\hline $0-500$ & Severely Corrosive \\
$500-1000$ & Very Corrosive \\
$1000-3000$ & Corrosive \\
$3000-10000$ & Moderately Corrosive \\
$10000-25000$ & Slightly Corrosive \\
Above 25000 & Relatively Corrosive \\
\hline
\end{tabular}

\subsubsection{Electrolytic Corrosion Cells}

Electrolytic corrosion cells are caused by stray direct current and can cause severe localized corrosion. A common source of stray direct current is the power distribution network of transit systems. The current is looking for the path of least resistance to travel along. This 
is supplied by the water main. The current enters at one point (the cathode), travels along the pipeline and then leaves to complete its intended circuit (the anode). The point at which the current leaves the water main (the anode) is where the corrosion occurs. The rate of corrosion is dependent upon the strength of the stray current and the resistivity of the soil.

\subsubsection{Bacterial Corrosion}

Corrosion can be caused by the actions of microorganisms. The typical class of organisms responsible for this are anaerobic, sulphate reducing bacteria of the genus Desulfovibrio and Desulphphatomuculum. These bacteria are naturally occurring and are typically found in sulphate rich, oxygen poor soils that have a temperature between $2^{\circ} \mathrm{C}$ and $60^{\circ} \mathrm{C}$ and a pH from 5.5 to 8.5 (Basalo 1992). Clays typically provide the most suitable conditions for bacterial growth because they are more likely to be anaerobic.

While it's agreed that sulphate reducing bacteria cause iron to corrode there are a number of competing theories about the causative mechanisms. One theory (originally Kuhr and Vlught 1934; referenced in Iverson 1984) states that during normal electrochemical corrosion a film of hydrogen forms on the cathode causing polarization. The film retards the current flow and lessens the strength of the corrosion cell. The sulphate reducing bacteria depolarize the cathode by removing the hydrogen film which had formed on it. The bacteria does this by reducing sulphate into sulphides. This causes the corrosion rate of the pipeline to increase and forms the corrosion product of $\mathrm{FeS}$ in addition to the original $\mathrm{Fe}(\mathrm{OH})_{2}$.

Additional research by Iverson (1984) indicates that corrosion may not be due to depolarization of the cathode but by a corrosive metabolic byproduct of the bacteria. If this product reaches the water main it initiates corrosion. However, this only occurs if the iron sulphide (also a byproduct of the bacteria) doesn't reach the water main first. If it does it forms a film protecting the water main from the corrosive byproduct. Corrosion depends on which material reaches the water main first.

\subsubsection{Acid Attack}

The $\mathrm{pH}$ level of the soil can directly and indirectly affect its corrosivity. If the $\mathrm{pH}$ is from 0.0 to 4.0 the soil is acidic and can directly corrode the cast-iron. An investigation into the relationship between total acidity and corrosion found that the rate of corrosion was proportional to the total acidity of the soils (Denison and Hobbs 1934). A low pH also means that the soil is a good electrolyte because more hydrogen ions are available to act as electron acceptors (AWWAVANSI C105/A25.5-99). 
Soils with a higher $\mathrm{pH}$ have an indirect effect on water main deterioration. If the $\mathrm{pH}$ is between $5.5-8.5$ the soil is suitable for the growth of sulphate reducing bacteria. If the pH is greater than 8.5 soils are high in dissolved salts lowering soil resistivity (AWWANANS C105/A25.5-99).

\subsubsection{Polarization}

Soil also plays a important role in how long galvanic corrosion can be sustained. Over time, corrosion products build up, reducing the voltage difference between the anode and cathode (called polarization). This slows the corrosion rate. If the soil is able to depolarize the anode or cathode by removing the products corrosion will continue for an extended period of time. Romanoff (1964) found that depending on the soil the corrosion rate of cast-iron can either remain linear or decrease after a few years exposure.

\subsection{Study Methodology}

This project had two goals. The first was to determine the geometrical and mechanical properties of the pipes making up the distribution network. This was done to identify defects in the pipes originating from the manufacturing process and to determine how the mechanical properties changed over time. This was accomplished by taking precise measurements of the pipe samples and subjecting them to tensile and ring bearing tesis.

The second goal was to test the soil samples for those properties $(\mathrm{pH}$, resistivity and sulphate reducing bacteria) identified as influencing a soil's corrosivity and to correlate those properties with the external corrosion rate of the water mains. It was also done to identify those areas of the city in which the distribution network is at increased risk for deterioration.

\subsubsection{Sampling Technique}

All six districts comprising the city of Toronto were invited to partake in this project. A total of 108 pipe and 98 soil samples were collected during this study. The majority of the samples came from the districts of Toronto and Etobicoke. Only 8 samples came from other districts. Of these, 6 came from the district of North York and 2 from the district of Scarborough. All but three of the pipe samples received were pit or spun cast grey iron. The remaining three were ductile iron.

The samples which were supplied to the University came from two sources. The majority were taken from the locations of water main breaks. The remaining samples were taker from access pits dug during cement mortar lining operations. 
Table 2.2 contains a summary of the data collected during the course of this study. Due to mistakes made in the field not all of the samples received consisted of both a pipe and soil sample. Early in the project many pipes arrived without an accompanying soil sample and vice versa. There was also difficulty in identifying the ages of all the pipe samples. For this reason there were only $\mathbf{5 5}$ pipe samples which had an established corrosion rate and a corresponding pipe sample.

Table 2.2 - Summary of Data Collected

\begin{tabular}{|c|c|c|c|}
\hline \multicolumn{4}{|c|}{ Data Collected } \\
\hline Samples & Total: & Trom Breaks & From Access Plits \\
\hline Pipe Samples Received & 108 & $7 / 3$ & 35 \\
\hline Soil Samples Received and Tested & 98 & 68 & 30 \\
\hline Complete Samples (Pipe and Soil) & 94 & 64 & 30 \\
\hline Pipes Measured for Corrosion & 97 & 62 & 35 \\
\hline Pipes Measured for Corrosion with Soil Sample & 84 & 54 & 30 \\
\hline Pipes with Established Corrosion Rates & 55 & 33 & 22 \\
\hline
\end{tabular}

One concern with gathering soil samples from the locations of main breaks is the effect that the released water might have had on the soil's properties. The water would increase the soil's moisture content possibly changing its resistivity, modifying its $\mathrm{pH}$ and potentialiy flushing away evidence of micro-bacterial corrosion. By having samples from disturbed and undisturbed locations it may be possible to see what effect this flushing had on the properties of the surrounding soil. This topic will be addressed further in the results section.

In all cases the following procedure was used to obtain the samples. The city crews were directed to take samples from the soil that surrounded the water main and deposit them in plastic bags. They were asked to "collect a soil sample close to the pipe, but not where the soil had been noticeably 'washed' by water from the pipe" (Seica et al. 2000). They were then to remove the appropriate section of pipe (preferably encompassing the failed section) and transport both samples to the University.

After being received, a portion of each soil sample was placed in a separate sealed plastic bag in order to preserve the soil's moisture content. This sample was used to determine the soil's sulphide content and $\mathrm{pH}$. The remaining sample was used to classify the soil and measure its resistivity. 


\subsubsection{Classification of Suil Samples}

Classification of the soil samples was done according to the ASTM D2488 standard. This standard identifies soils through simple visual-manual tests and classifies them as silts, clays, sands and gravels.

\subsubsection{Soil Resistivity Test}

The resistivities of the samples were determined in a laboratory setting using the Wenner four-electrode method (ASTM G57 standard). The samples were placed into a soil box which had two outer and two inner electrodes. A constant voltage of $12 \mathrm{~V}$, supplied by a Hewlett Packard E3612A direct current power source, was applied to the outer electrodes and the current and voltage drop across the inner electrodes was measured using a digital multimeter. The readings were recorded when the values reached equilibrium.

The resistivity of a soil can be affected by factors such as the degree of compaction, temperature and moisture content. Since soil resistivity was not measured in the field all of these factors changed from their in-situ values. There was no way to compensate for this problem. Soil resistivity was not measured in-situ due to contract specifications with the City of Toronto.

All effort was made to insure uniformity among the resistivity tests performed in the laboratory. All soil samples were tested at room temperature $\left(21^{\circ} \mathrm{C}\right.$ - which remained constant) and an effort was made to compact the soils to the same degree into the soil box.

As mentioned, moisture content can have a large effect on a soil's resistivity. The more water present, the lower the soil's resistivity. According to ASTM G57, the tests should be performed on saturated samples. In the case of cohesionless soils this was easily achieved by adding a sufficient amount of distilled water. For clays and other cohesive soils it was decided to test them in an "as received state" due to the time and difficulty involved in saturating them. In all cases, the samples were tested as soon as possible after delivery. Unfortunately, early in the project some cohesive soil samples were delivered in burlap or torn plastic bags and arrived in a dry state. These cohesive samples had to be saturated with distilled water in order to test them. The samples are identified in the Appended data tables.

\subsubsection{Soil Sulphide Content Test}

AWWAVANSI standard C105/A25.5-99 recommends a sodium azide iodine solution to qualitatively test for sulphides. Sulphides in the soil catalyzes the reaction between the 
sodium azide and iodine producing nitrogen. The stronger the bubbling the higher the soil's sulphide content.

Instead of using this test, it was decided to quantitatively determine the amount of sulphides present in the soil using the following procedure.

Ten grams of soil were mixed with $90 \mathrm{ml}$ of distilled water into a $500 \mathrm{ml}$ flask. Next, $5 \mathrm{ml}$ of concentrated $\mathrm{HCl}$ acid was added and the flask sealed. The $\mathrm{HCl}$ reacted with the sulphide salts and ions changing them into $\mathrm{H}_{2} \mathrm{~S}$ gas. This solution was briefly mixed a second time to make sure that the $\mathrm{HCl}$ was completely dispersed into the solution.

The amount of $\mathrm{H}_{2} \mathrm{~S}$ gas released was measured using a Gastech detector tube attached to a calibrated pump. The Gastech tube is a commercial product consisting of a glass tube containing a lead acetate powder. Sulphides in the air sample react with the lead acetate turning it brown. The pump drew $100 \mathrm{ml}$ of air from the flask. The amount of $\mathrm{H}_{2} \mathrm{~S}$ gas present in the air was then read off of the tube in parts per million.

To convert ppm of $\mathrm{H}_{2} \mathrm{~S}$ into $\mathrm{mg}$ of $\mathrm{S}_{2}$. per $\mathrm{kg}$ of dry soil the following equation was used (Seica at al. 2000):

$$
S_{2 .}=0.0867(\mathrm{ppm})(w / 100+1)
$$

where: $\mathrm{ppm}=$ amount of $\mathrm{H} 2 \mathrm{~S}$ gas in parts per million

$w=$ moisture content of the soil

\subsubsection{Soil pH Test}

Soil pH was measured in accordance with the ASTM G51 standard. Before each test the $\mathrm{pH}$ meter was rinsed with distilled water and calibrated in a neutral buffer solution. Ten grams of soil were mixed into a $500 \mathrm{ml}$ flask with $90 \mathrm{ml}$ of distilled water. The sample was allowed to stand a few minutes to allow any soluble salts to dissolve. The reading was recorded when the $\mathrm{pH}$ value reached equilibrium.

\subsubsection{External Pitting Corrosion Measurements}

The external corrosion was found by sandblasting the pipes to remove any graphite deposits. This was necessary because grey cast-iron is a composite of iron and graphite. During corrosion the iron goes into solution leaving black graphite flakes behind. The graphite retains the original shape of the pipe, camouflaging the areas of corroded cast-iron. 
The depths of the five largest corrosion pits (including holes) were then determined using a mechanical pit depth measurement gauge. The pit depth gauge was manufactured by W.R.Thorpe \& Co. It consists of a plunger arm which is inserted into the mouth of the pit. The depth to which the arm reaches can then be read off a graduated scale.

The only difficulty in measuring the external and internal corrosion pit was when the pipe wall was completely perforated. In most of these cases it was possible to determine whether the pit initiated externally or internally based on the shape of the pit. Pits which initiated externally generally had a wedge shape with widest part found on the exterior of the pipe. It is entirely possible that in many cases the external pit met an internal pit. However, it is impossible to determine when and if this occurred.

\subsection{Analysis/Discussion of Results}

\subsubsection{Soil Resistivity}

The 95 soil samples tested ( 3 of the 98 soil samples received did not contain enough material to perform a resistivity test) exhibited a wide range of resistivities. As shown in Figure 2.1, the majority of the samples taken from break locations had saturated resistivities lower than $2000 \Omega \cdot \mathrm{cm}$. The majority of samples taken from the access pits had resistivities lower than $5000 \Omega \cdot \mathrm{cm}$. Based on previous work, cast-iron water mains surrounded by soil with a resistivity of $2000 \Omega \cdot \mathrm{cm}$ or lower have been found to be at increased risk for corrosion (see Table 2.1).

Grouping the soils by classification found that, as expected, the clays had the lowest average resistivities and sands had the highest (see Figure 2.2). It was also observed that while the resistivity values of the clays tended to be close to the average value, the resistivities of the sands and gravels were spread over a wide range. For example, the resistivities of the poorly graded sands (SP) ranged from a low of $3084 \Omega \cdot \mathrm{cm}$ to a high of $16433 \Omega \cdot \mathrm{cm}$. The low values were unexpected as sands typically have higher resistivities than clays. This same pattern was noted for clayey sands (SC) and gravels (GP and GW). It should be noted that only soil types with two or more samples were included in this figure (the same rule was applied to the figures depicting the $\mathrm{pH}$ range and the sulphide content range).

One possible explanation for the lower than expected resistivities is that some of these soils were contaminated by road salt. A previous study (Cathodic Technology Ltd. 1988) of water main corrosion in the former borough of North York, Toronto, Ontario found that 40 out of 50 
Figure 2.1 - Histogram of Soil Resistivity

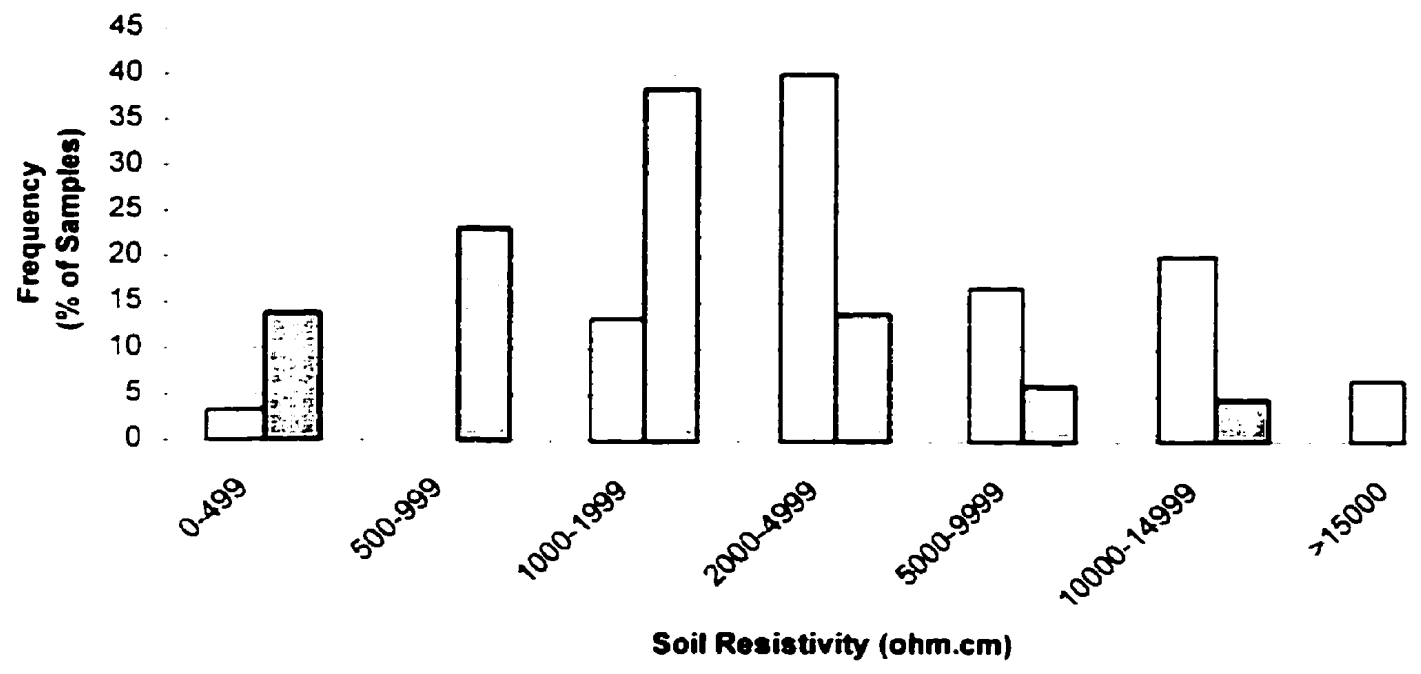

口Access Pits Samples QBreak Samples

Figure 2.2 - Resistivity Range by Soil Type

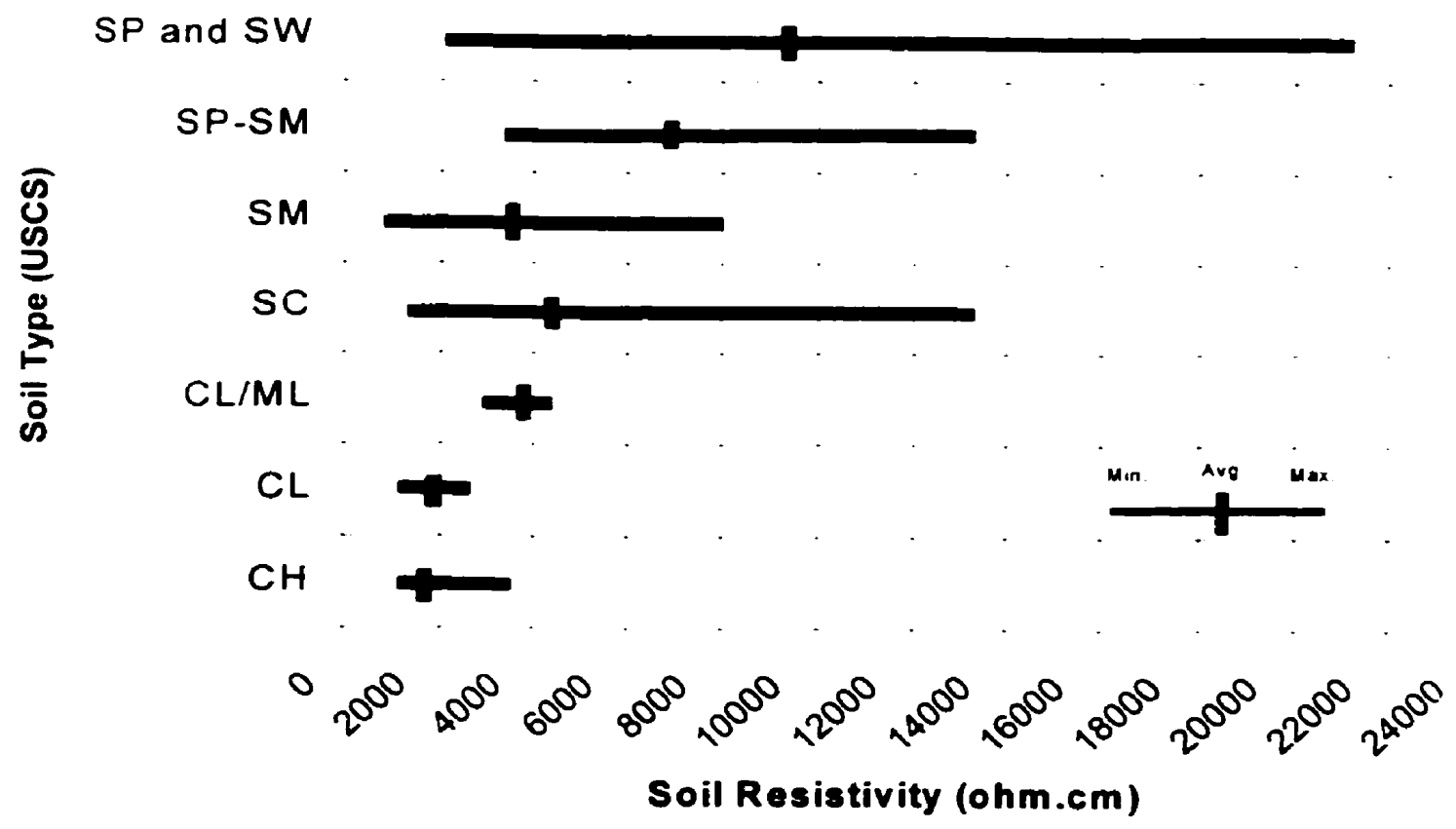


soil samples had chloride levels greater than 200ppm. It is logical to assume that soils in the rest of the city would be similarly contaminated by chloride ions.

It is also possible that the iron ions released at the anode may lower the resistivity of the soil but this is unlikely. The ferrous iron $\left(\mathrm{Fe}^{2+}\right)$ released at the anode reacts with water to form ferrous hydroxide $\mathrm{Fe}(\mathrm{OH})_{2}$. Ferrous hydroxide is soluble in water, so potentially a situation still exists in which $\mathrm{Fe}^{2+}$ ions can affect the resistivity of the soil. However, ferrous hydroxide reacts with oxygen in the soil to form ferric hydroxide $\left(\mathrm{Fe}(\mathrm{OH})_{3}\right)$. This is an insoluble compound and gives the soil a reddish-brown colour (the typical rust colour). The incorporation of $\mathrm{Fe}^{2+}$ ions into the insoluble corrosion product $\mathrm{Fe}(\mathrm{OH})_{3}$ prevents them from having a large influence on the resistivity of the soil.

The location of the water main could account for some of the variance in soil resistivity. If the water main was located underneath a grass boulevard melting snow would transport the salt into the soil. Since sands and gravels are much more permeable than clays, the contaminated water would quickly reach the soil surrounding the water mains. The increased ion content in the porewater of these soils would greatly reduce their resistivity. On the other hand, a water main located in similar soil but covered by a sidewalk would be protected from chloride contamination.

Unlike sands and gravels, clays and silts are less affected by chloride contamination for two reasons. First, because they are less permeable, the concentration of chloride ions takes longer to build up. Secondly, since clays and silts already have low resistivities they are less sensitive to the effect of chloride ion contamination.

\subsubsection{Soil pH}

The $\mathrm{pH}$ measurements showed that all of the 98 soil samples were either neutral or alkaline in nature (having a pH of between 7.0 and 10.5) eliminating the possibility of direct corrosion due to acid attack on the pipe wall. The majority of the samples had a pH ranging from 8.0 9.4 (see Figure 2.3). Soils which have a pH in this range do support the growth of sulphate reducing bacteria. Both the break samples and access pit samples had similar $\mathrm{pH}$ distributions.

Figure 2.4 depicts the $\mathrm{pH}$ range by soil type. $\mathrm{pH}$ appears to be independent of soil type as the average $\mathrm{pH}$ values where quite similar from one soil type to another. 


\subsubsection{Soil Sulphide Content}

The majority of the 98 soil samples tested had sulphide contents lower than $2 \mathrm{mg} / \mathrm{kg}$ dry soil (see Figure 2.5). Only five samples (all from break locations) had sulphide levels greater than $7.00 \mathrm{mg} / \mathrm{kg}$ dry soil. These high sulphide levels indicate the presence of sulphate reducing bacteria. Three of these samples came from within the district of Etobicoke and were geographically disparate.

Referring to Figure 2.6 it can be seen that the soil types with the highest maximum sulphide contents were fat clays (USCS classification of $\mathrm{CH}$ - high plasticity clays) and sandy clays (SC). This indicates that clayey soils are the soil type most likely to promote the growth of sulphate reducing bacteria. This was expected as clays are the soil type most likely to have the anaerobic conditions necessary for bacterial growth.

Two of the high sulphide soils from the district of Etobicoke were clays which had a very noticeable blue colour. Though not referring to the Toronto area specifically a paper by Klein and Rancombe (1985) stated that blue clays are usually high in sulphate content and aggressive towards cast-iron. Unfortunately, the authors did not state where these clays came from or present any evidence explaining this relationship.

If additional investigations support the theory that blue clays do have high sulphate contents (supporting sulphate reducing bacteria) and are very aggressive towards cast-iron water mains it may be beneficial to map out the location of this soil formation in Toronto. This could be done using public domain borehole logs from previous construction projects in the Toronto area. It would then be known how large an area of the distribution network was at risk. 
Figure 2.3 - Histogram of Soil pH

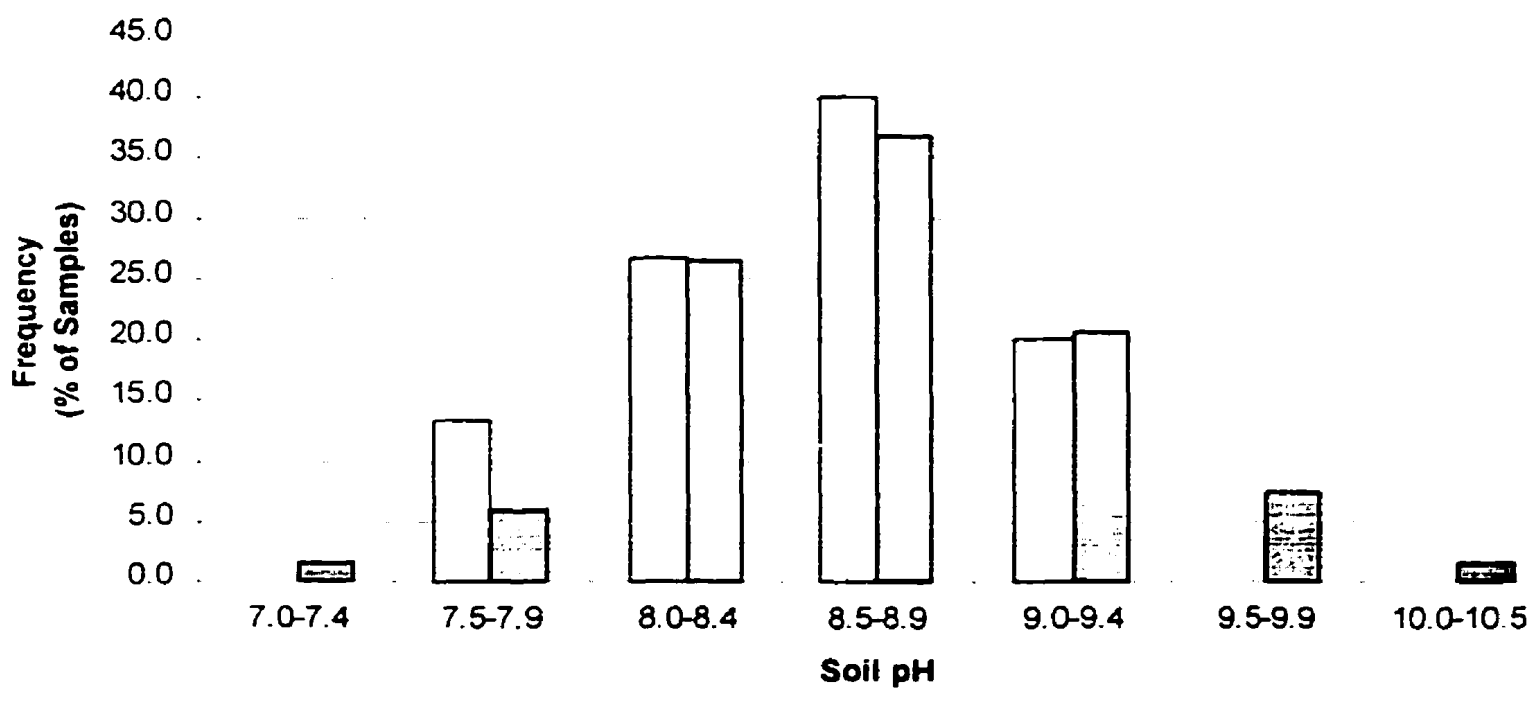

$\square^{A c c e s s}$ Pit Samples $\square$ Break Samples

Figure 2.4 - pH Range by Soil Type

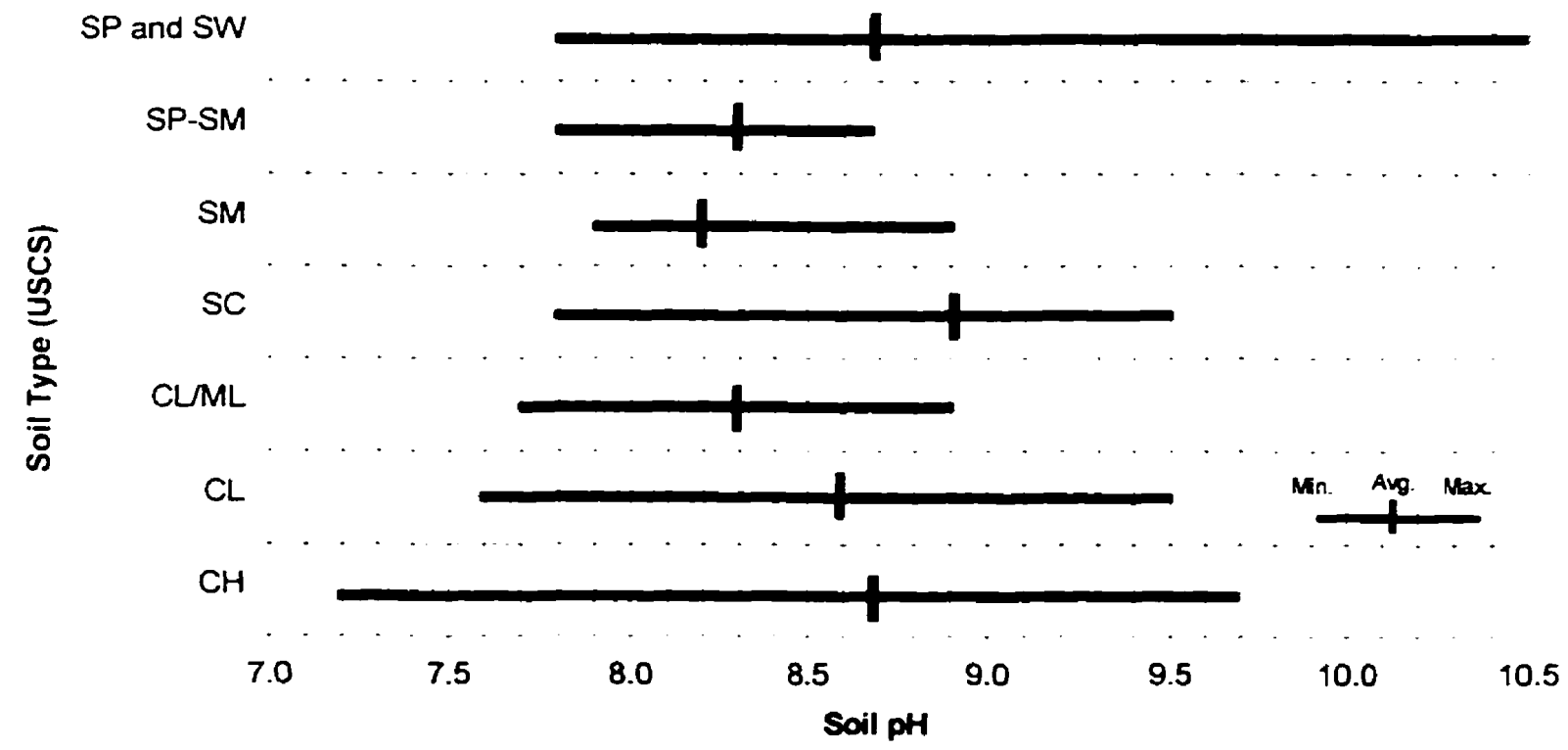


Figure 2.5 - Histogram of Soil Sulphide Content

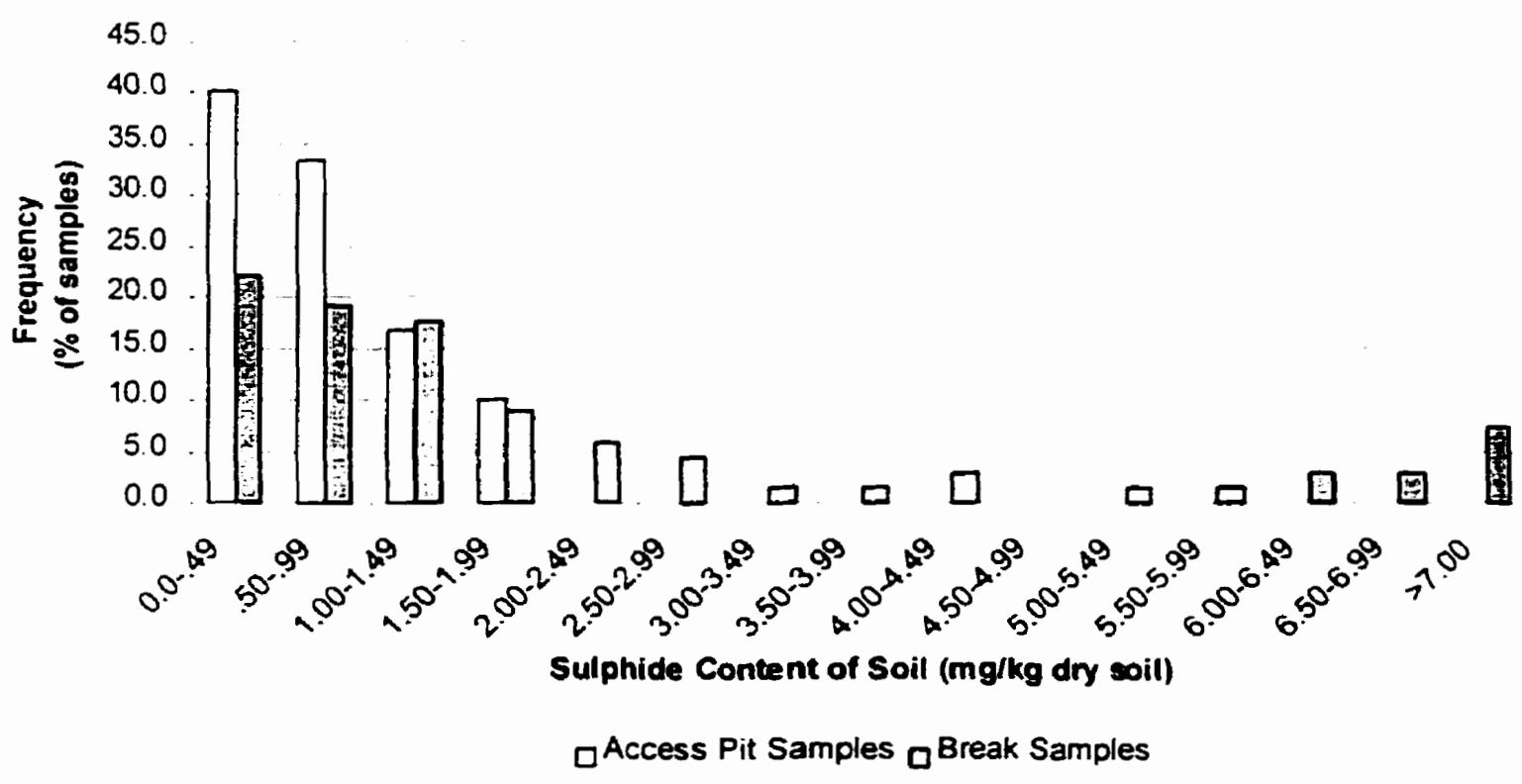

Figure 2.6 - Range of Sulphide Content by Soil Type

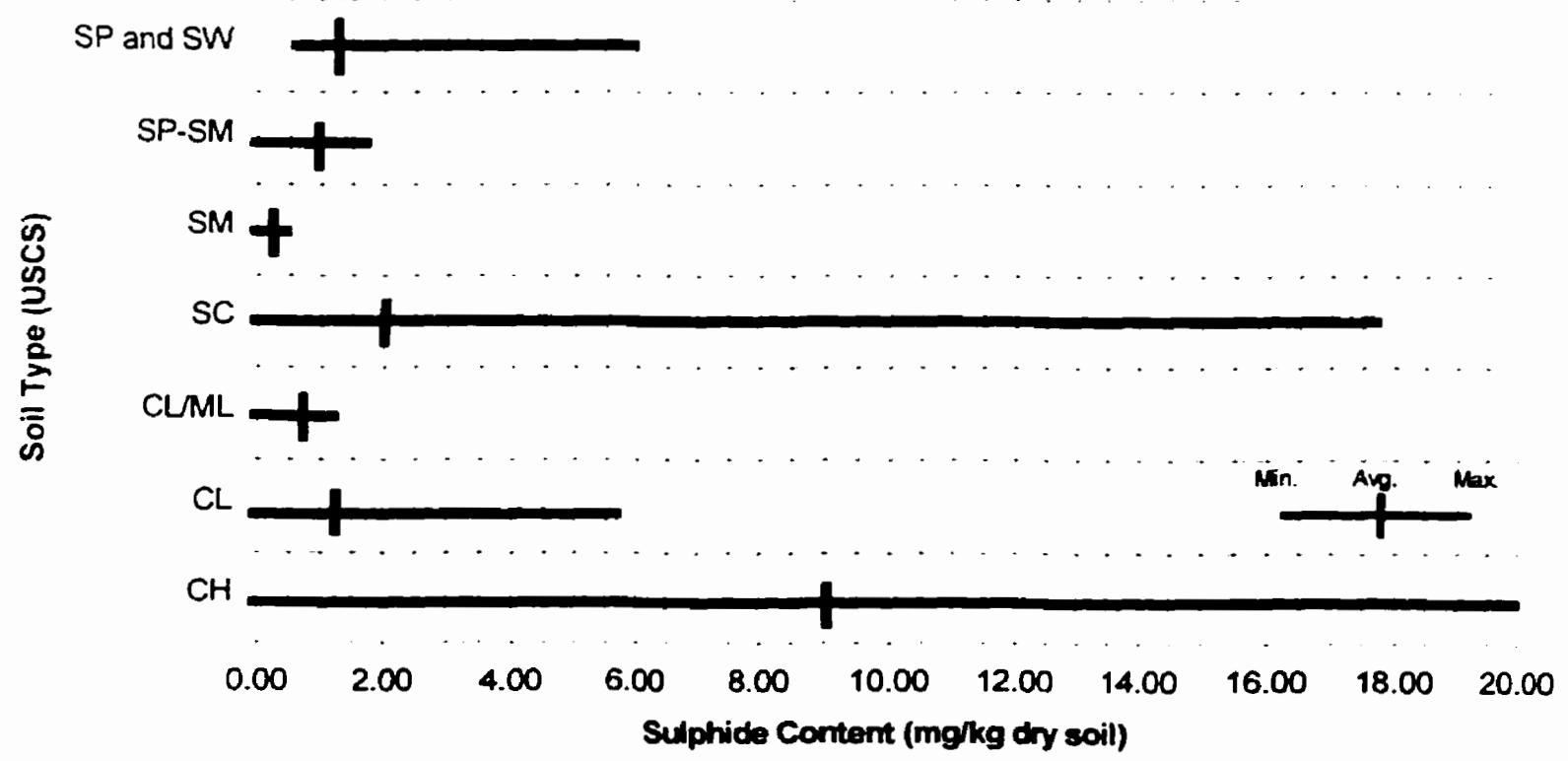




\subsubsection{AWWA Soil Corrosiveness Rating}

Scoring systems have been developed by different groups to rate the corrosivity of a soil towards cast-iron pipes. The American Water Works Association and the American National Standards Institute have established such a criteria in the standard ANSI/AWWA C105/A21.599 (see Table 2.3).

The scoring system works by assigning a point value to each of the following soil properties: resistivity, sulphide content, redox potential, moisture content. Points are assigned for each property and totaled. If the score is over 10 the soil is considered corrosive towards gray and ductile cast-iron.

Some modifications to the scoring system were necessary to apply it to this study. As the presence of sulphides is only qualitatively defined in the standard it was necessary to relate a "positive" result to a specific sulphide content. It was decided that a sulphide content greater

\section{Table 2.3 - AWWA Soil Corrosivity Scoring System}

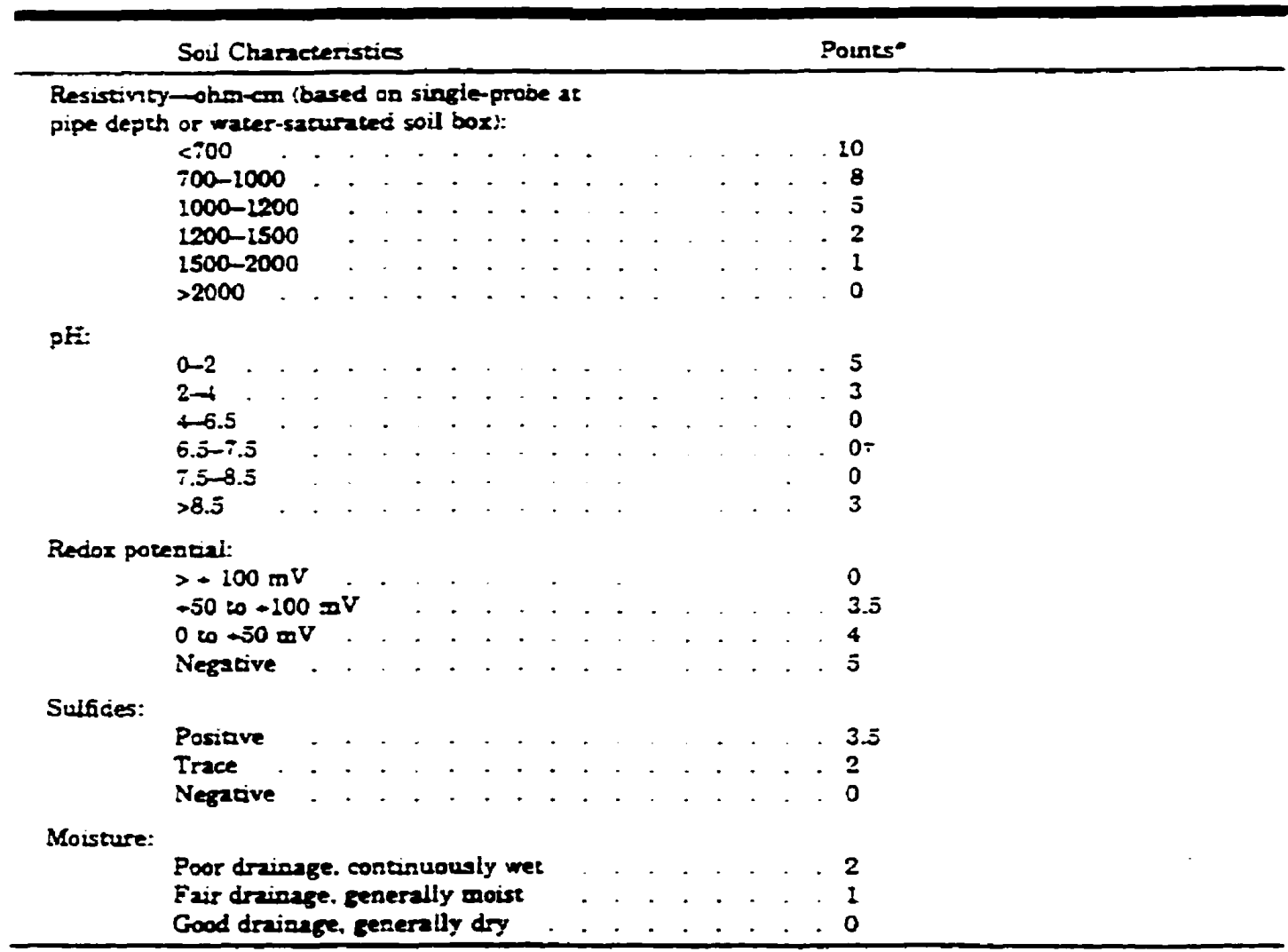

Ten points mens that soil is corrosive to gray or duceile cast-iron pipe: pretection is indicaced

fIf sulfides are preseat and low or negative redox-potensial results are obvainec give three points for this rasge. 
than $2 \mathrm{mg} / \mathrm{kg}$ dry soil indicated a positive test. This value was chosen because it was found during this study that the external pitting rate was two times higher if the soil had a sulphide content greater than $2 \mathrm{mg} / \mathrm{kg}$ dry soil. This increased pitting rate could be attributed to sulphate reducing bacteria.

Also, as this study did not test for redox potential it was decided to estimate this parameter based on soil type and sulphide content. Redox potential can loosely be correlated to soil type. Clays are most likely to be anaerobic and have low redox potentials. Sands and gravels are less likely to be anaerobic and therefore have higher redox potentials.

In this study, if the soil was a clay then it was assigned a point value of 3.5 . If the soil had a abnormally high sulphide content (clearly indicating the presence of sulphate reducing bacteria) it was assigned a point value of 5 . All other soils were scored as zero. It is recognized that there is a possibility for error in estimating the redox potentials in this manner. For purposes of comparison the results using the scoring system with and without the redox parameter have been provided. Finally, it was also assumed that the soil surrounding the water mains was generally moist and had fair drainage.

The AWWA scoring system was applied to the 84 soil samples whose accompanying pipe sections were examined for evidence of external corrosion (see Table 2.4). The AWWA system correctly predicted $93 \%$ of the soils observed as "corrosive" to be "corrosive". However, when used to identify soils which were "non-corrosive" the scoring system was only correct $36 \%$ of the time. Adding the soil's redox potential only had a minimal effect on the results. The percentage of soils correctly predicted as "corrosive" dropped to $91 \%$ and the percentage correctly predicted as "non-corrosive" rose to $38 \%$.

Based on these results it can be stated that if the AWWA system identifies a soil as "corrosive" it is probably correct. However, if it identifies a soil as "non-corrosive" it is probably wrong. Effectively, this means that the AWWA scoring system is not a useful tool for identifying which soils are "corrosive" and "non-corrosive". Because the uncertainty is so large with regards to a "non-corrosive" prediction, from a practical point of view it is best to assume that all soils are corrosive towards cast-iron if only the AWWA system is used.

Additionally, the AWWA scoring system cannot be used to reliably predict the maximum external pitting rate of a cast-iron pipe. Referring to Figure 2.7 it can be seen that the data relating maximum external pitting rate to the AWWA score is very scattered and that a wide 
range of pitting rates exist for each score. However, with the exception of a few outlying points it appears that the AWWA score may provide an indicator of the upper bound for the external pitting rate. If confirmed by additional data this would be a useful tool in establishing the "worst case" situation a water main would experience.

Table 2.4-Results of the AWWA Scoring System

\begin{tabular}{|c|c|c|c|c|}
\hline \multirow{2}{*}{ Oberved } & \multicolumn{2}{|c|}{ Prodictied } & \multicolumn{2}{|c|}{ Predictod (with rodox) } \\
\hline & Corrosive & Not Comosive & Corrosive & Not Corrouive \\
\hline Corrosive & 39 & 25 & 43 & 21 \\
\hline Not Comorive & 3 & 14 & 4 & 13 \\
\hline
\end{tabular}

\subsubsection{Pitting Depth vs. Age}

Plotting the maximum external pitting depth versus age found no correlation between the two properties (see Figure 2.8). A linear regression analysis of the data resulted in an $r^{2}$ value of only 0.02 . As such, pipe age is not a reliable indicator of the amount of external corrosion a pipe will experience.

\subsubsection{Correlating External Pitting Rate to Soil Properties}

Previous studies have attempted to identify which soil factor best correlates to externa! pitting rate with varying degrees of success. In a study investigating water main corrosion in Ontario (Gummow and Wakelin 1993) the soil corrosiveness was found to best correlate with soil resistivity when strong galvanic couples existed. A study done on Calgary's water mains (Jakobs and Hewes 1987) found that external pitting penetration decreased with increasing soil resistivity. Conversely, a study of Philadelphia's water system (originally Weiss et al. 1985; referenced in O'Day 1989) found a poor correlation between corrosion rate and soil resistivity.

Statistical techniques have also been applied to the problem of predicting external corrosion. An investigation into the relationship between soil properties and the corrosion of buried highway culverts (originally Noyce and Ritchie 1979; referenced in O'Day 1989) was only able to explain $10 \%$ of the variance in corrosion through a linear regression analysis.

The lack of success in applying statistical techniques is part of the reason why no standard equations have been developed to predict underground corrosion as a function of soil properties. Another problem is that even if such equations were available lack of information would make their use difficult. For example, the City of Toronto has no database available containing detailed information on the properties of the soil surrounding the water mains. 


\section{Figure 2.7 - Maximum External Pitting Rate vs. AWWA Score}

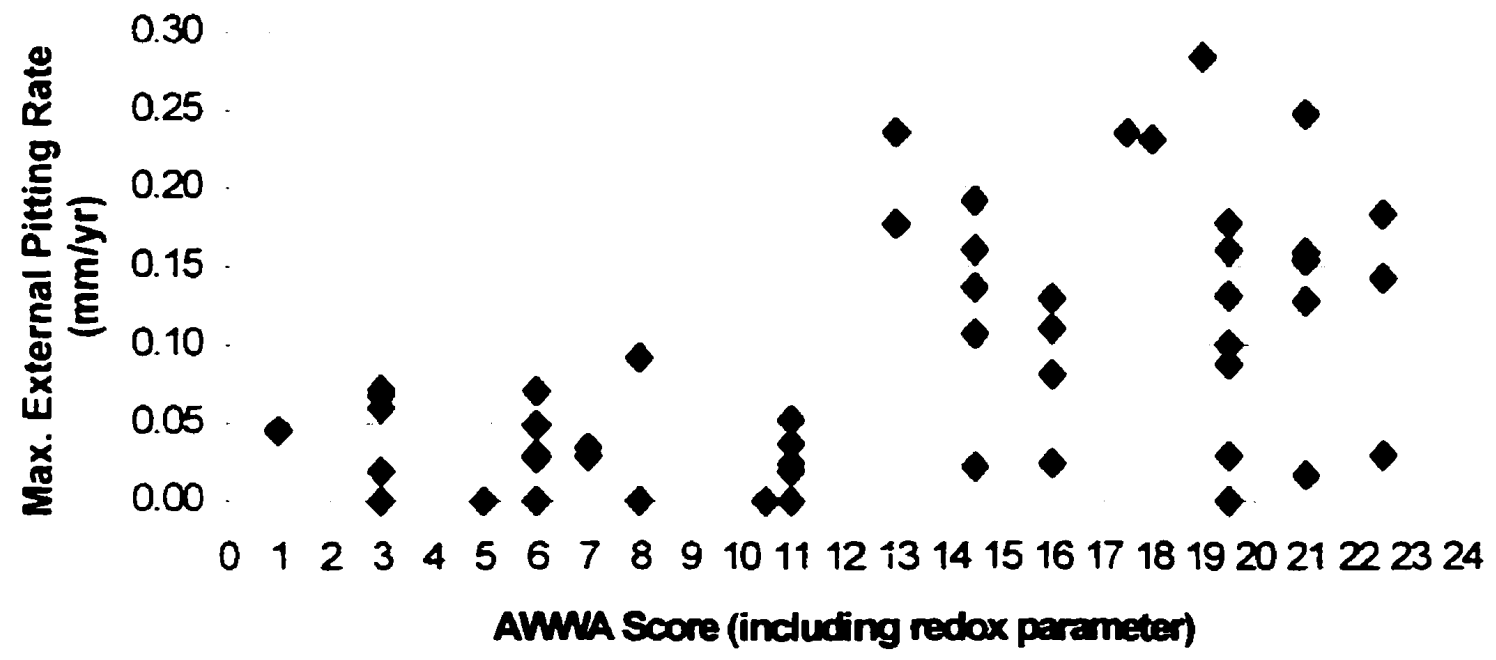

Figure 2. 8-Maximum External Pitting Depth vs. Age of Pipe

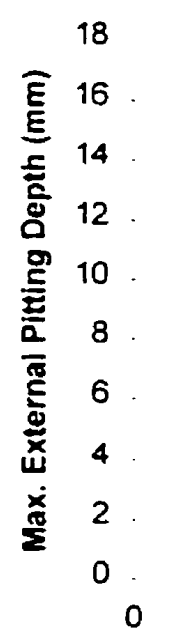

$$
\begin{gathered}
y=-0.0234 x+6.6986 \\
R^{2}=0.02
\end{gathered}
$$

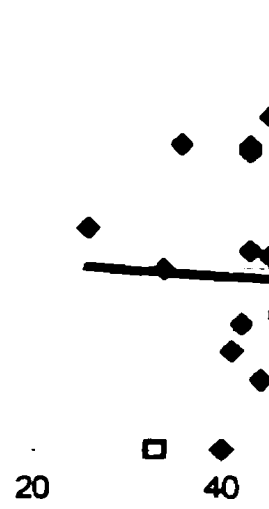

- Water Main Breaks 由Access Pits 
The external pitting rates were only able to be established for 68 of the 108 pipe samples collected during the course of this study (the City of Toronto was unatle to provide ages for the remaining pipes). The number of data points was further reduced as only 55 of the pipes with known pitting rates had corresponding soil samples. All of these 55 pipe samples came from locations in the districts of Toronto and Etobicoke.

The maximum external pitting rates for the 55 pipes were plotted against the three soil properties (soil resistivity, $\mathrm{pH}$ and sulphide content) to produce the graphs shown below (Figures 2.9, 2.10 and 2.11). In all of the plots, the samples taken from the locations of water main breaks have been differentiated from those taken from access pits. The data referring to the two ductile iron pipe samples has been omitted.

\subsubsection{Soil Resistivity vs. Maximum External Pitting Rate}

The data collected in this study showed that the external pitting rate of cast-iron water mains decreased as resistivity increased (see Figure 2.9). This was true for samples taken from both break and repair locations.

This relationship does not appear to be linear and was best captured by a logarithmic regression line (see Figure 2.9). The rate of external pitting markedly increased when the soil resistivity was lower than $2500 \Omega \cdot \mathrm{cm}$.

This was confirmed by looking at the average pitting rate over a range of resistivities. Referring to the entire data set, from 0 to $500 \Omega \cdot \mathrm{cm}$ the average pitting rate was $.11 \mathrm{~mm} / \mathrm{yr}$. The pitting rate became half that over the range of 1500 to $2000 \Omega \cdot \mathrm{cm}(.058 \mathrm{~mm} / \mathrm{yr})$ and seven times less over the range of 2500 to $3000 \Omega \cdot \mathrm{cm}$.

Referring to Figure 2.9, there is no conclusive evidence what effect the flushing by fresh water had on the resistivity of the soil samples taken from the locations of water main breaks. While the majority of these samples had lower resistivity values compared to those taken from access pits this could be due to a number of reasons.

The resistivity of these samples could have been lowered due to increased moisture content. Moisture content would have been further modified during transport. However, another explanation for this difference is that if resistivity was the controlling factor with regards to the external pitting rate it would be logical that soil samples taken from water main breaks would have lower resistivities than those taken from access pits. 


\subsubsection{Soil pH vs. Maximum External Pitting Rate}

The data relating $\mathrm{pH}$ to external pitting rate were very scattered. A linear regression analysis of the data found no strong correlation between the two properties (see Figure 2.10). This was true for samples taken from break as well as access pit locations.

This was expected as all of the soils were alkaline ruling out corrosion by acid attack. Alkaline soils only have an indirect effect on the corrosion rate of cast-iron pipelines by making the soil suitable for bacterial growth and/or being high in dissolved salts (lowering resistivity).

\subsubsection{Soil Sulphide Content vs. Maximum External Pitting Rate}

The data relating maximum external pitting rate to the sulphide content of the soil was very scattered. As shown by the linear regression line plotted through the data no strong correlation between the two properties was evident (see Figure 2.11).

Comparing the corrosion rates of the pipes to the sulphide content of the soil found that the pipes in soil with a sulphide content higher than $2 \mathrm{mg} / \mathrm{kg}$ dry soil had an average pitting rate two times higher than those in soil with a lower sulphide content. This is a very tenuous relationship based on limited data and additional investigation is needed, but perhaps a sulphide content of $2 \mathrm{mg} / \mathrm{kg}$ dry soil is an indicator of the threshold at which bacterial activity has an effect on the pitting rate.

\section{Figure 2.9 - Maximum External Pitting Rate vs. Soil Resistivity}

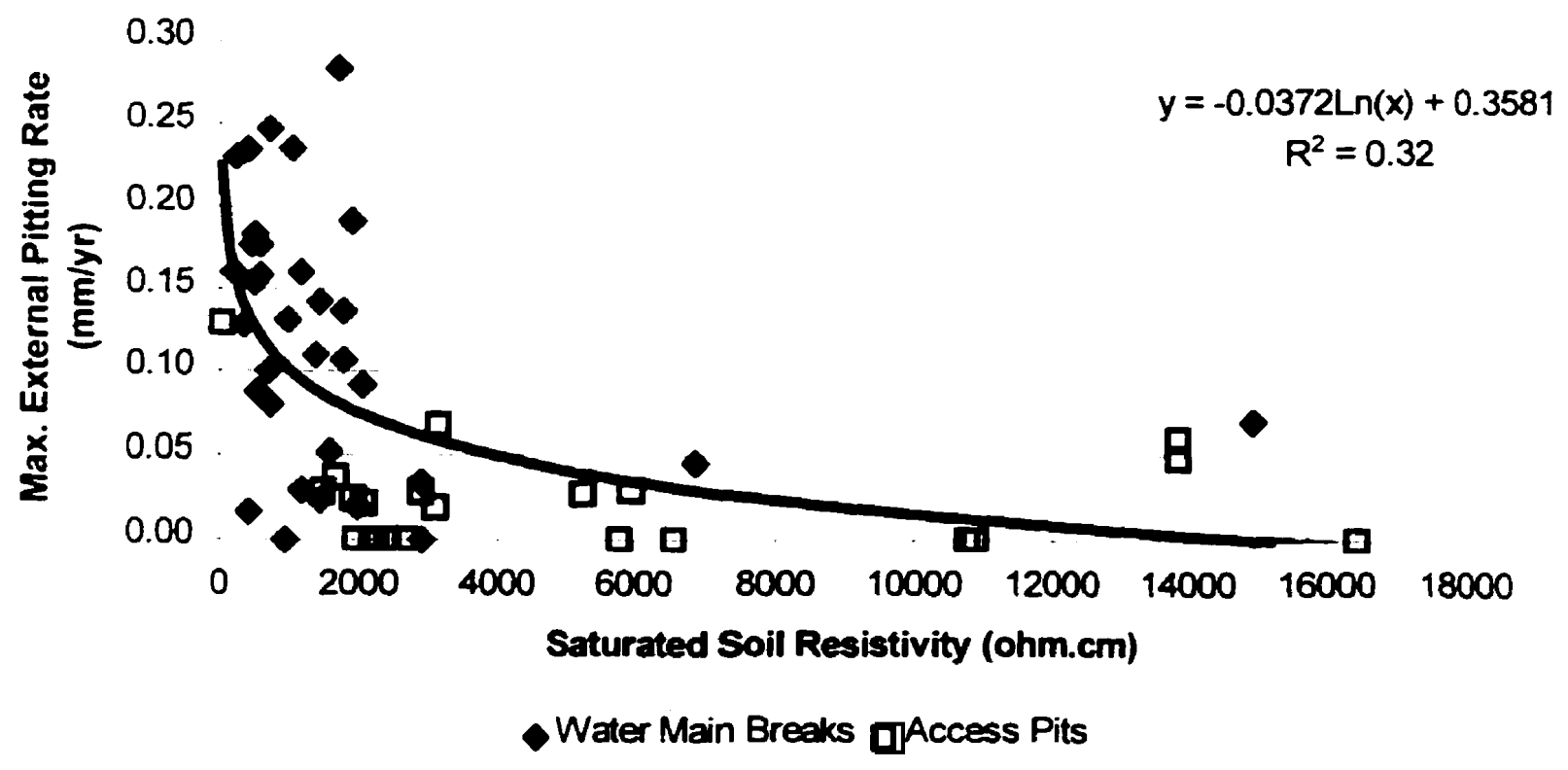


Figure 2.10 - Maximum External Pitting Rate vs. Soil pH

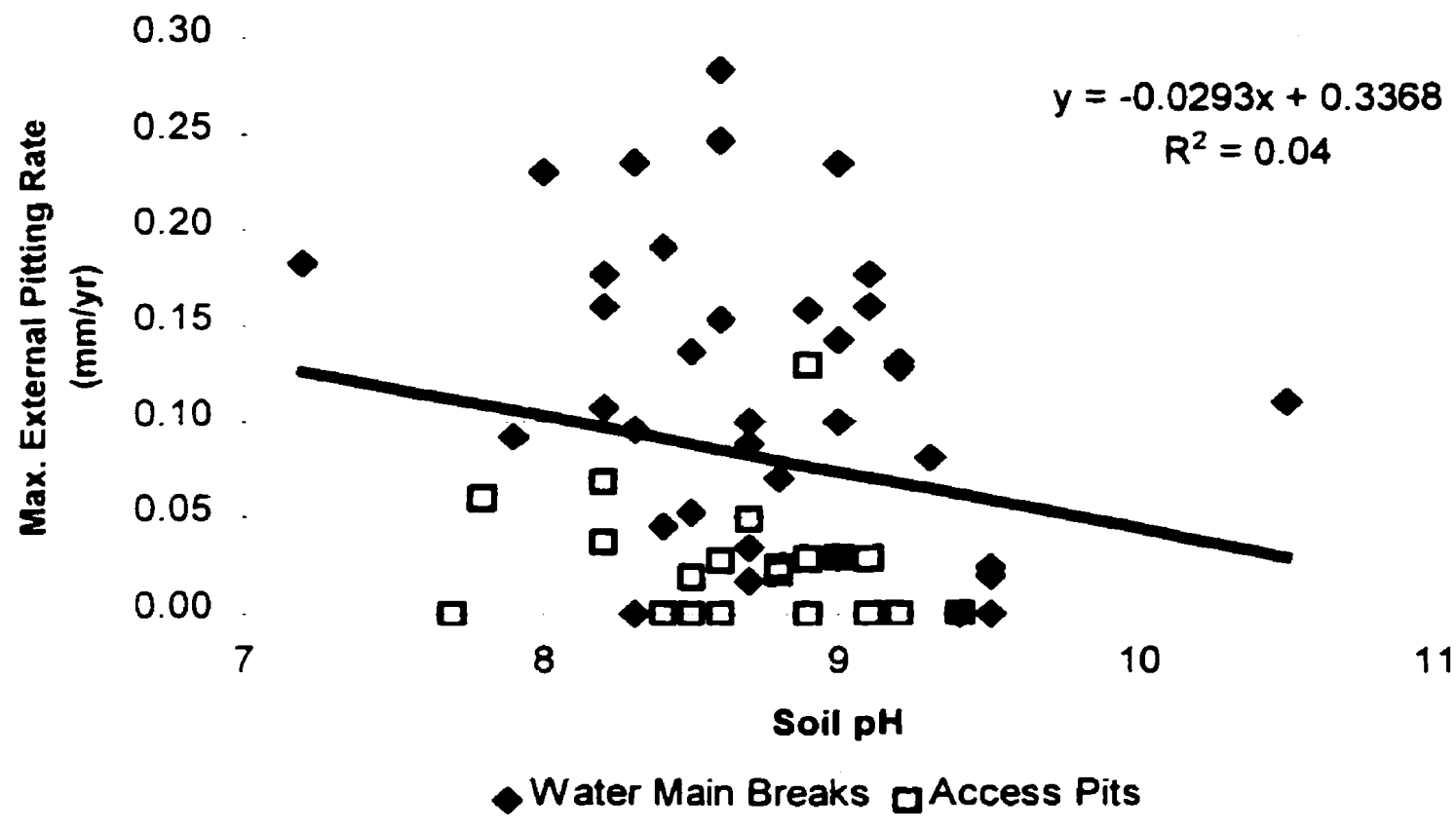

Figure 2.11 - Maximum External Pitting Rate vs. Sulphide Content of Soil

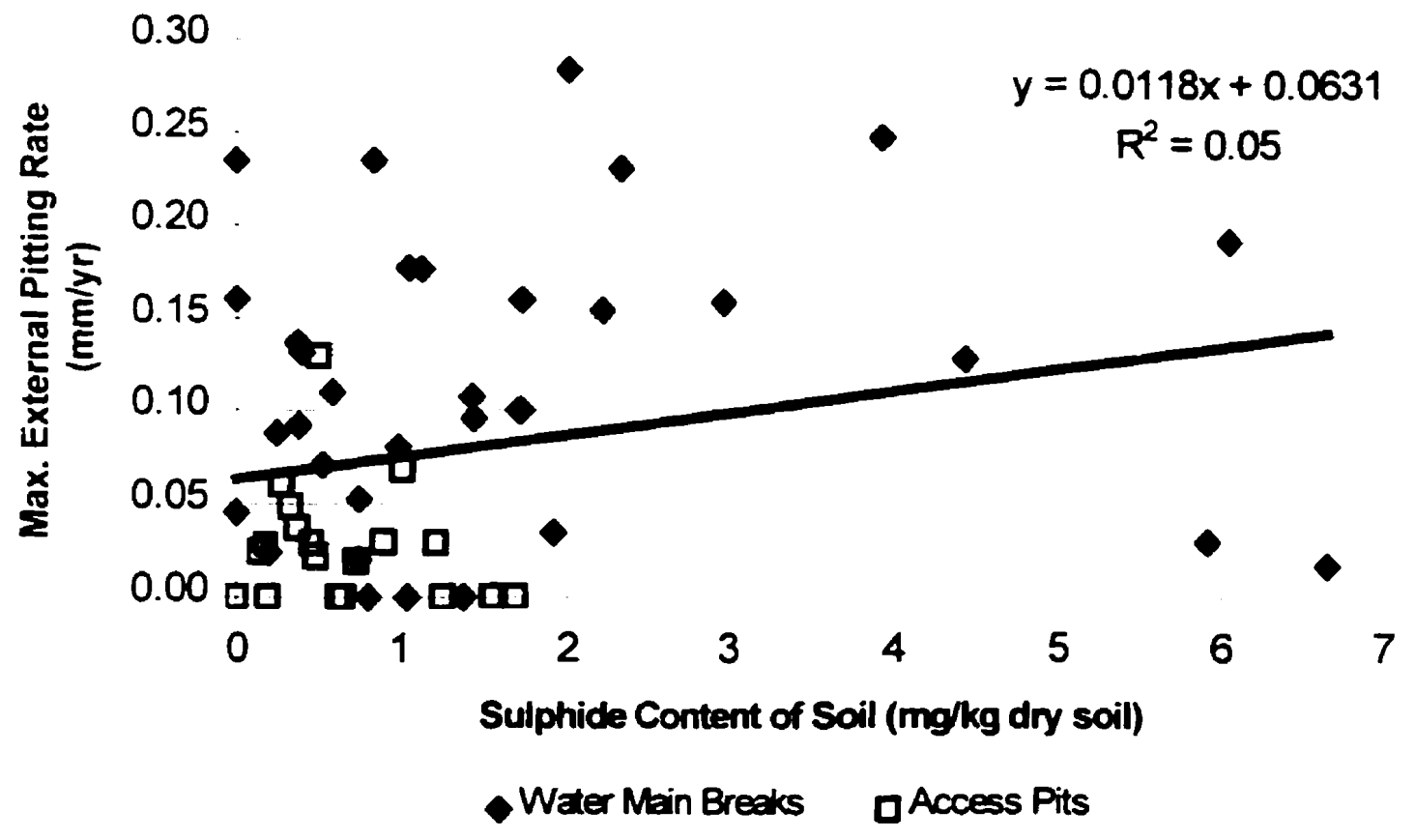




\subsubsection{Statistical Analysis}

The dataset was iriputted into a statistical software package (Statistical Analysis Software (SAS) v8, The SAS Institute) to further look for correlations between external corrosion and soil properties. A linear regression model was then developed to see what combined effect the soil properties had on explaining the variance in the external pitting rate.

A statistical term which can be used to look for relationships between data is the Pearson Correlation Coefficient $\left(r_{p}\right)$. This term "indicates the strength of a linear relationship existing between two continuous variables" (Cody, Smith 1997). A value close to 1 or -1 indicates a strong relationship. An $r_{p}$ of zero means the variables are unrelated. Associated with the Pearson Correlation Coefficient is a "p value". The $p$ value is the probability of "obtaining a samples correlation coefficient as large or larger than the one obtained by chance alone" (Cody, Smith 1997).

\subsubsection{Correlation Between Soil Properties}

All of the samples, for which both the corrosion rates and soil properties were available. were blocked by sampling location (breaks vs. access pits) and inputted into SAS. The results found that regardless of location, the log of soil resistivity had the strongest correlation with the maximum external pitting rate (see Table 2.5).

However, while resistivity had the highest correlation coefficient $(-0.56)$ it alone does not account for all of the variation in the pitting rate. The $r_{p}^{2}$ of the maximum pitting rate/log of soil resistivity correlation (for all samples) was only 0.32 . In other words, $68 \%$ of the variance in pitting rate was due to factors other than soil resistivity.

Table 2.5 -Correlation Coefficients for Maximum External Pitting Rates and Soil Properties

\begin{tabular}{|c|c|c|c|c|c|}
\hline & sulphide & PH & moisture & Tesistivity & log(resistivity) \\
\hline \multirow{2}{*}{ Max. Pitting Rate } & 0.15 & -0.22 & 0.44 & -0.40 & -0.56 \\
\hline & 0.29 & 0.11 & 0.00 & 0.00 & 0.00 \\
\hline & \multicolumn{5}{|c|}{ Carsez-Plisthiples $(n=24)$} \\
\hline & suphide & PH & moisture & resistivity & Tog(resistivity) \\
\hline \multirow{2}{*}{ Max. Pitting Rate } & -0.18 & -0.16 & 0.39 & \multirow{2}{*}{$\begin{array}{c}-0.13 \\
0.57\end{array}$} & -0.57 \\
\hline & 0.41 & 0.48 & 0.08 & & 0.01 \\
\hline \multicolumn{6}{|c|}{ 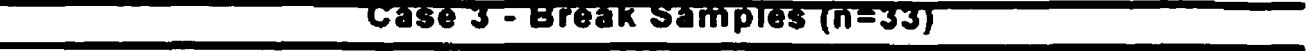 } \\
\hline & sulphide & PH & moisture & resistivity & log(resistivity) \\
\hline \multirow{2}{*}{ Max. Pitting Rate } & 0.07 & -0.38 & 0.03 & -0.27 & -0.41 \\
\hline & 0.68 & 0.03 & 0.86 & 0.12 & 0.02 \\
\hline
\end{tabular}




\subsubsection{Linear Regression Model}

A multi-variate linear regression analysis was performed to develop a model which could be used to explain the variance in the maximum external pitting rate. Various models were tried and it was found that the best one used the variables $\mathrm{pH}$ and the log of resistivity. The influence of variables such as sulphide and moisture content had an negligible effect on the model's accuracy. This resulted in the linear regression model:

$$
\begin{aligned}
& Y=0.6874-0.0370 X_{1}-0.0887 X_{2} \\
& \text { where: } \begin{aligned}
Y & =\text { predicted maximum external pitting rate of the pipe wall }(\mathrm{mm} / \mathrm{yr}) \\
X_{1} & =\text { soil } \mathrm{pH} \\
X_{2} & =\log \text { of soil resistivity }(\Omega \cdot \mathrm{cm})
\end{aligned}
\end{aligned}
$$

This model had an adjusted $r^{2}$ value of 0.41 . One outlying data point was removed because its observed corrosion rate was an extreme value that did not correlate well with its soil properties. The high corrosion rate may possibly have been due to stray direct current or some other external factor. The pipe material may also have been incorrectly identified as grey cast-iron instead of ductile cast-iron.

A comparison between the observed external pitting values and those predicted by the model is presented in Figure 2.12. The data parallels the line of one-to-one correspondence but is quite spread out from it. Generally the model underestimated the external corrosion rate. For this reason some negative values were generated. This was believed to occur because the dataset contained a number of pipe sections observed to have zero external corrosion but which were surrounded by soil which had resistivity and $\mathrm{pH}$ values comparable to the soil surrounding pipes which did experience external corrosion. In order to reconcile this conflict the model underestimated the predicted external pitting rates.

The fact that pipes with similar soil properties had different rates of external corrosion leads to the conclusion that some factor(s), other than the soil properties measured by this study, is/are needed to accurately predict the external pitting rate. It may not be possible to accurately predict the external pitting rate based on soil properties alone. This missing factor may be the strength of the current flow between the anode and the cathode.

Metal loss at the anode is proportional to the current flow. The amount of current flow is dependent upon the potential (voltage) across the cell and the resistance through the cell. The resistance through the cell is a function of the soil's resistivity and can be modified by 
factors such as $\mathrm{pH}$ and the presence of additional ions in the porewater. As shown in this study these properties are easily measured.

Determining the voltage potential across the cell is a more difficult process because it is a matter of identifying the cathode. The cathode may be a section of the pipeline with a lower potential or it may be the copper service or a lead joint or a nickel bolt. In every case the voltage potential would be different. Adding to the problem is that the potential between the anode and the cathode changes over time due to polarization. The value measured at the time sampling would be lower than that when the corrosion process initiated.

If the voltage potential had been similar in each case it is likely that the regression model would have had a higher $r^{2}$ value; indicating that soil properties alone could be used to predict the external pitting rate. However, the available evidence indicates that this was not the case and that the difference in potential between the cathode and anode is a necessary factor to more accurately predict the external pitting rate.

\section{Figure 2.12 - Predicted vs. Observed Maximum External Pitting Rates}

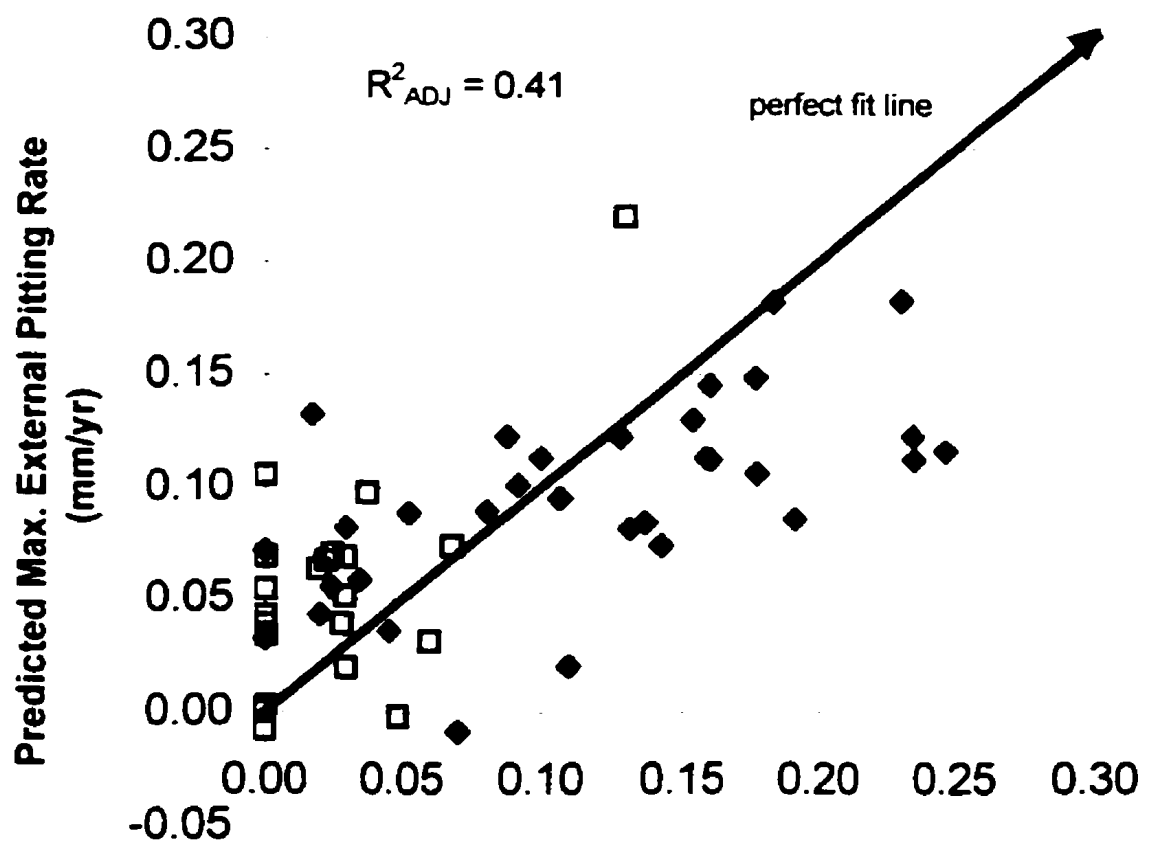

Observed Max. External Pitting Rate (mm/yr)

Water Main Breaks aAccess Pits 


\subsubsection{Validity of Data}

From the data gathered in this study its appears that the water released from a main break does not have an appreciable influence on sulphide content or $\mathrm{pH}$ of the soil. Evidence of bacterial activity was not washed away as samples taken from the location of main breaks were found to have high sulphide contents. The $\mathrm{pH}$ of samples taken from water main breaks were comparable to those taken from access pits.

There is no conclusive evidence that fresh water flushing had an effect on the soil's resistivity. However, it must be remembered when interpreting the data that in all cases the resistivity values found in the laboratory are likely not the same as those which would be found in the field. This is not to say that this data is invalid. The lab values are believed to be close to the field values but not identical. When grouped by classification the resistivity values of the soil samples agreed with those found in the literature.

\subsubsection{Preliminary Spatial Analysis}

A non-traditional method for interpreting the data collected during this study is to input it into a Geographic Information System (GIS) and spatially analyze the data. A preliminary effort was begun to analyze the data in this manner. A future paper will look at how utilities are using this technology to plan and prioritize their water main rehabilitation programs. The data gathered during the City of Toronto project will also be more fully analyzed at that time.

The locations and associated data of the samples collected from the cities of Toronto and Etobicoke were inputted into the commercial GIS package ArcView (ArcView v.3.1, ESRI). At this time, the limited amount of data available enables only generalized conclusions to be drawn using this technique. As more data becomes available the patterns drawn from the GIS will become less generalized. It is believed that by geographically referencing the soil data and the condition of the water main samples (with regards to the extent of external corrosion) it may be possible to identify which areas of the city are most susceptible to water main corrosion.

The GIS used in this preliminary analysis consisted of three data layers. The first layer was a geocoded centre-line street map of the districts of Etobicoke and Toronto. This map was used to locate the sampling sites. A geocoded map allows locations to be accurately plotted based on street addresses. 
The second layer contained the data collected during this study. The locations were known for 79 of the pipe and soil samples supplied by the city. Attributed to each location was the data about the soil properties and the external corrosion of water main section collected during this project. This data was stored in the dBase IV (Borland, Inc.) format.

The third layer was a surficial soil map. This map (created by the author) is a digitized version of Ontario Geological Survey Map P. 2204. This soil map is very general in scale and identifies the large surficial soil formations found in the city of Toronto. This map was included to allow users to see what areas of the city may be at risk due to surficial soil type (clays or gravels or sands). This map was not based on the soil samples collected during this study. As additional data becomes available a more refined and detailed soil map of the city could be created.

The City of Toronto is presently considering developing such a soil map to predict storm water runoff (Klimas pers. comm. 2000). This map is to be created using borehole logs in the public domain. Such a map could easily be adopted for use in a GIS to predict the risk water mains are at for exterior corrosion by associating the soil data collected from sampling with a specific soil formation.

A preliminary analysis of the data indicated that, in general, the water main samples from the district of Etobicoke have had a higher pitting rate and show more evidence of corrosion than those taken from the district of Toronto (see Figure 2.13). Figure 2.14 shows the resistivities of the collected soil samples superimposed onto the city street map. From this figure it can be seen that, with one exception, the soil samples from Etobicoke had resistivities lower than $2000 \Omega \cdot \mathrm{cm}$. In comparison, the majority of the soil samples from the district of Toronto had resistivities greater than $2000 \Omega \cdot \mathrm{cm}$. Since, as shown by this study, low soil resistivity increases the risk for external corrosion, Etobicoke's water mains are potentially at greater risk than those located in the district of Toronto.

Creating a GIS may be the best way to identify which parts of the city's distribution network are most at risk for deterioration. By building a database that combines information about soil properties, water main characteristics, historical performance and critical customers (those who would be severely affected by service disruptions; eg. hospitals) informed decisions could be made about whether it would be better to replace or repair a section of water main. 


\section{Figure 2.13 - Maximum External Pitting Rate Superimposed onto the City Street Map}

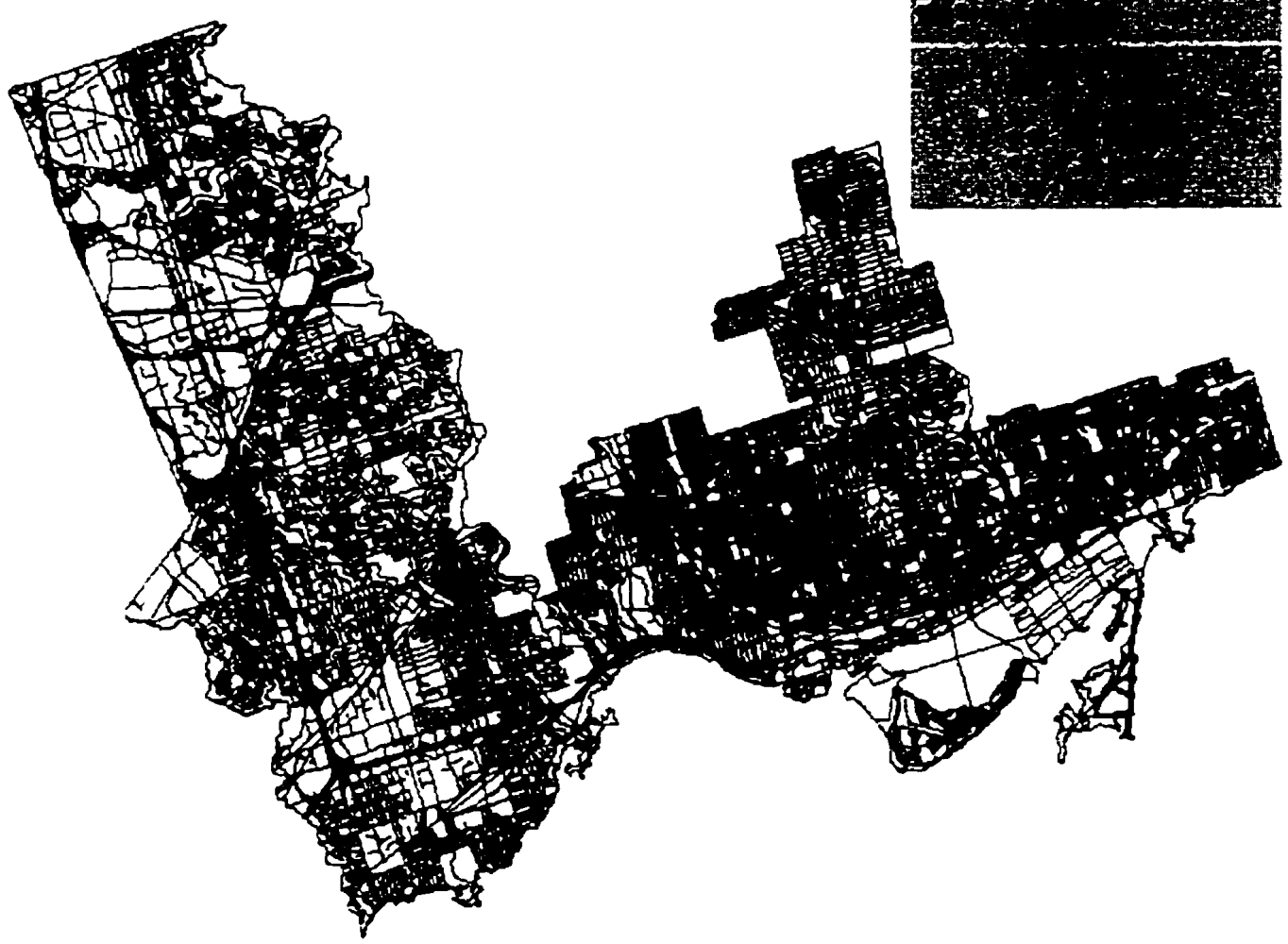

Figure 2.14 - Resistivity of Collected Soil Samples Superimposed onto City Street Map

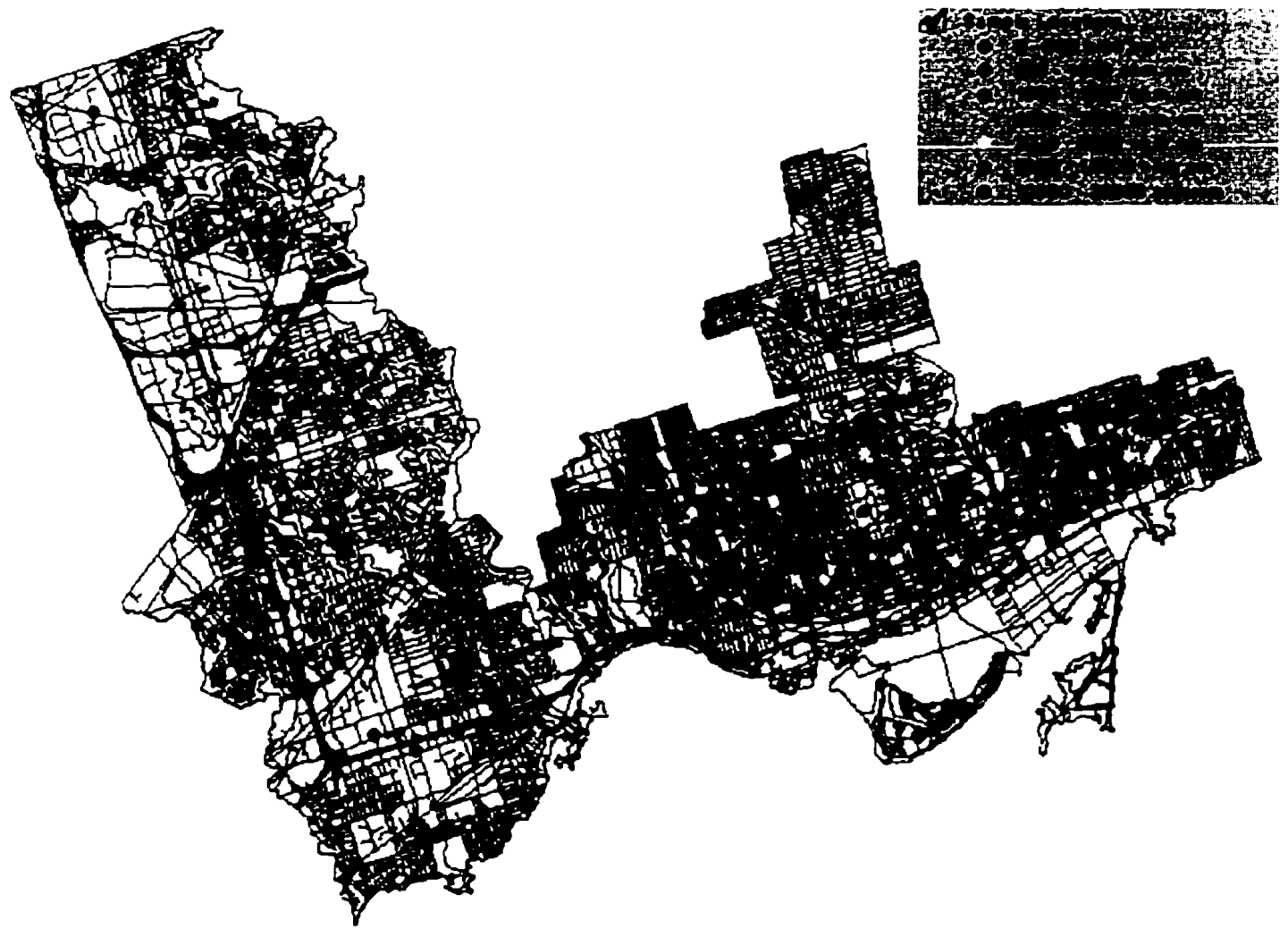


Such a database would also allow managers to make better decisions about what preventative methods to apply. For example, sacrificial anodes are commonly used to prolong the life of cast-iron water mains. However, if corrosion were being caused by sulphate reducing bacteria or acidic soil, sacrificial anodes may not be the optimal solution.

This technique has been adopted by the city of Seattle. In order to identify water mains in need of maintenance and rehabilitation a statistical program (Pipe Evaluation System (PIPES), Roy F. Weston Inc.) has been combined with the data about the water mains stored in the city's GIS. A report on this project (Bodner, Lim 1999 pers. comm.) states that "water engineers and managers have seized upon the advantages of accessing water main characteristic information through Seattle's GIS and have significantly reduced the time spent identifying and prioritizing water mains for preventative maintenance, rehabilitation or replacement".

In order to make these decisions "a custom decision-support application was developed to leverage the GIS water main characteristic data with statistically based decision models to improve decision making. Correlation of water main characteristics with time-to-failure factors identified statistically significant failure prediction indicators. Based on the identified indicators, decision models were developed for evaluating deterioration, vulnerability and service criticality factors" (Bodner, Lim 1999 pers. comm.). The results of these models were used to prioritize water main replacement or rehabilitation efforts.

\subsection{Recommendations}

As a result of this project the following recommendations are suggested for further investigations into water main corrosion in Toronto. The first is that in future studies the measurement of soil properties should be made in the field. This could be accomplished with a modified CPT rig set up to test for resistivity, $\mathrm{pH}$ and soil redox potential. However CPT testing typically requires large trucks to carry the rig and provide the necessary jacking force. A more portable piece of equipment would be preferable.

One possibility is a soil probe commercially known as the 'Novaprobe". Described in a 1995 article (Wilmott et al, 1995) this probe was designed by NOVA Gas Transmission Ltd. and Novacor Research and Technology Corp to specifically test for those soil properties known to influence external corrosion. At the time that article was written the probe was able to test for resistivity, redox potential, soil temperature and pipe to soil potential. The probe is pushed by 
hand through an augured guide hole up to a depth of $1.9 \mathrm{~m}$. Data are stored in a handheld acquisition system. The article indicated that future modifications would allow the probe to test for soil pH and reach deeper locations. Attempts to locate more recent information about this product have so far been unsuccessful.

If such a product is still commercially available it would be ideal for developing a database about the properties of the soil surrounding Toronto's water mains. A testing program using this equipment would also be cost efficient. After the initial purchase of the probe, testing could be done by a few workers. Also, since the probe can be inserted by hand it means that setup and tear down times would be quite fast allowing a large number of samples to be taken in a short time period.

Secondiy, the various districts of Toronto actively engage in cement mortar lining of water mains to maintain water quality and improve hydraulic characteristics. During such times the distribution network is out of service and customers are on bypass. This would be an opportune time to take pipe and soil samples from undisturbed locations. In combination with samples taken from the location of water main breaks a much more complete picture of the factors affecting water main corrosion would emerge.

One important lesson learned from this study is that the causes of corrosion are variable and subject to localized factors (such as micro-bacterial corrosion, underground power lines, etc). A small number of samples are unsuitable for determining the causes of water main corrosion over an area as large as Toronto. Collecting and developing a database about soil properties and water main corrosion for the city the size of Toronto is a long term project. The data collected from such a test program could be stored in a Geographic Information System (GIS). Spatially referencing the data would allow managers to see those factors affecting a particular area of the network and allow them to better apply specific rehabilitation methods.

\subsection{Conclusions}

This paper has reached the following conclusions:

- Resistivity is the soil property which correlates most closely with the maximum external pitting rate.

- The AWWA soil corrosiveness scoring system does a poor job in identifying soils as "noncorrosiven towards cast-iron water mains. Only $36 \%$ of the soils observed to be "non- 
corrosive" were predicted to be "non-corrosive". Effectively, this means that the AWWA scoring system is not a useful tool for identifying soils as "corrosive" or "non-corrosive".

- Based on the available data, a linear regression model was only able to account for $41 \%$ of the variance seen in the maximum external pitting rate. This indicates that the degree of external corrosion can not be reliably predicted based on soil properties alone.

- Generally, water mains in the City of Toronto are not at risk for deterioration due to sulphate reducing bacteria. However, there is some evidence indicating that water mains in the northern part of the district of Etobicoke are potentially at increased risk for microbiological corrosion. Additional investigations are needed to confirm this.

- Based on the collected samples, a preliminary spatial analysis indicates that water mains in the district of Etobicoke have had a higher rates of external corrosion than those taken from the district of Toronto. Also, the majority of soil samples taken from the district of Etobicoke had resistivities lower than $2000 \Omega \cdot \mathrm{cm}$. Since, as shown by this study, low soil resistivity increases the risk for external corrosion, Etobicoke's water mains are potentially at greater risk than those located in the district of Toronto.

\subsection{Acknowledgements}

This research was funded and supported by the City of Toronto, Canada. The Authors would also like to thank Professor Jeff Packer and Michael Seica for organizing this project and providing technical data on the pipe samples collected during the course of this research.

\subsection{References}

ANSI/AWWA C105/A25.5-99. American National Standard for Polyethylene Encasement for Ductile-Iron Pipe Systems. American Water Works Association, Denver Colorado.

ASTM D2488-93 (1993). Standard Practice for Description and Identification of Soils (VisualManual Procedure). American Society for Testing and Materials, New York, New York.

ASTM G46-94. Standard Guide for Examination and Evaluation of Pitting Corrosion. American Society for Testing and Materials, New York, New York.

ASTM G51-95. Standard Test Method for Measuring pH of Soil for Use in Corrosion Testing. American Society for Testing and Materials, New York, New York.

ASTM G57-95a. Standard Test Method for Field Measurement of Soil Resistivity Using the Wenner Four Electrode Method. American Society for Testing and Materials, New York, New York.

Basalo, C. (ed.). 1992. Water and Gas Main Corrosion, Degradation and Protection. Ellis Horwood Limited, Great Britain. 
Baillie, A. 2000. Water Crisis Rattles Faith in Public Institutions. The Toronto Sun. June 5, 2000.

Bodner,N. and Lim, E.L. 1999. Water Main Decision Support System Seizes Advantages. City of Seattle, Washington - Personnel Communications.

Brennan, R. 2000. Walkerton Water Pipes to be Replaced. The Toronto Star. July 25, 2000.

Cathodic Technology Ltd. September, 1988. A Report to the City of North York on Soil Sample Analysis in Various Streets in the City: Prepared for the City of North York. Cathodic Technology Ltd., Bolton, Ontario.

Cody, R., Smith, J. 1997. Applied Statistics and the SAS Programming Language. Simon and Schuster, Upper Saddle River, New Jersey.

Denison, I.A. and Hobbs, R.B. 1934. Corrosion of Ferrous Metal in Acid Soils. J. Research NBS 13.

Gummow, R.A. and Wakelin, R.G. 1993. A Summary of the Findings of Recent Water Main Corrosion Studies in Ontario. Institute for Research in Construction, Ottawa.

Hertzler, P.C, Davies C. 1997. The Cost of Infrastructure Needs. Journal American Water Works Association, 89: 42-49.

Iverson, W.P. 1984. Mechanism of Anaerobic Corrosion of Steel by Sulfate Reducing Bacteria. Materials Performance. March, 1984. pp. 28-30.

Jakobs, J.W. and Hewes, F.W. Underground Corrosion of Water Pipes in Calgary, Canada. Materials Performance, 26(5): 42-49.

Klein, R.L., Rancombe, A.J. 1985. Performance of Water Pipeline Materials. Chemistry in Industry, n. 11, June, pp. 353-358.

Kilmas, R. 2000. City of Toronto, Ontario. Works and Emergency Services. Personal Communications.

Kuhr, C.A.H and Vlught, L.W. 1934. Water, 18: 147.

Miller. F.P. et al. 1981. Soil Surveys: Their Synthesis, Confidence Limits, and Utilization for Corrosion Assessment of Soil. Underground Corrosion. ASTM Manual STP 741, ASTM, Philadelphia, Pa.

Noyce, R.W. and Ritchie J.M. 1979. Galvanized Metal Culvert Corrosion Study. Transportation Res. Recording 713. Transportation Res. Bd., National Academy of Science, Washington, D.C.

O'Day, D.K. 1989. External Corrosion in Distribution Systems. Journal American Water Works Association, 81(10): 44-52. 
Ontario Geological Survey. 1980. Quaternary Geology - Toronto and Surrounding Area, Ontario Geological Survey Map P.2204

Robinson, W. 1993. Testing Soil for Corrosiveness. Materials Performance, 32(4): 56-58.

Romanoff, M. 1964. Exterior Corrosion of Cast-Iron Pipe. Journal American Water Works Association, 60(12): 1129-1143.

Seica et al. 2000. Evaluation and Testing of Cast-iron and Ductile Iron Water Main Samples - Final Report to City of Toronto, Department of Civil Engineering, University of Toronto. Toronto, Ontario, June 2000, ISBN: 0-7727-7551-6.

Singley et al. 1985. Corrosion Prevention and Control in Water Treatment and Supply Systems. Noyes Publications; Park Ridge, New Jersey.

Smith. H.J. 1989. Corrosion Management in Water Supply Systems. Van Nostrand Reinhold, New York, N.Y.

Weiss, R et al. 1985. Philadelphia Water Supply Infrastructure Study. U.S. Army Core of Engineers, Philadelphia District.

Wilmot et al. 1995. Soil Probe Measures Several Properties to Predict Corrosion. Oil and Gas Journal, 94(14): 54-58. 
2.11 Appendix - Summary of Collected Data

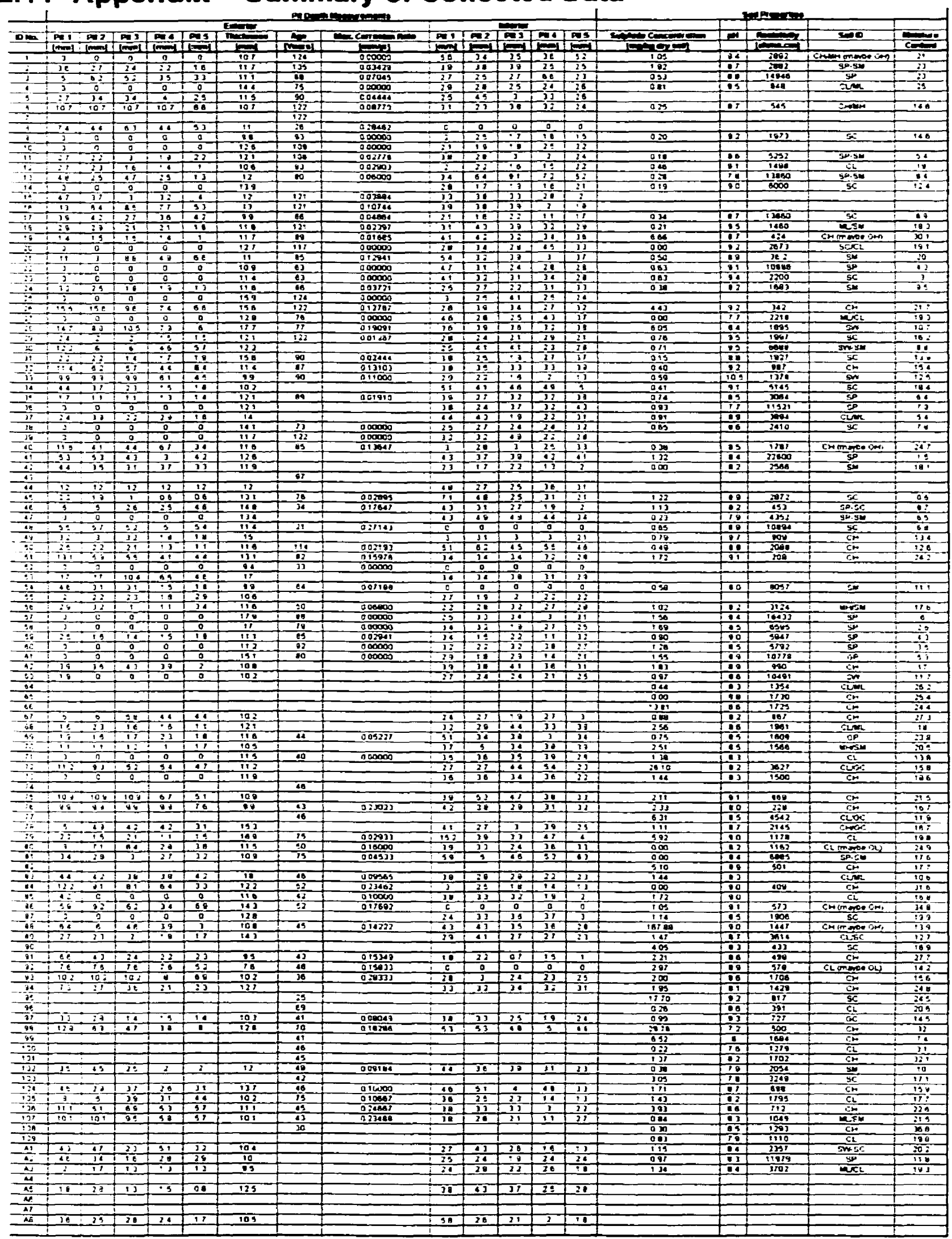




\subsection{Paper Two}

\section{The Application of GIS to a Water Main Corrosion Study}

\subsection{Abstract}

Recently the City of Toronto, Ontario conducted an investigation into the deterioration of the city's water distribution network. One part of the investigation focused on the effects soil has on the external corrosion of water mains. External corrosion is a function of the interaction between the pipeline and the soil by which it is surrounded. A soil's "corrosiveness" towards cast-iron is affected by properties such as resistivity, $\mathrm{pH}$ and the presence of sulphate reducing bacteria. It was decided to input the collected data into a Geographic Information System (GIS) and perform a spatial analysis to look for trends and patterns. This paper consists of two parts. The first section presents the results of a survey of 35 cities regarding how they are using Geographic Information Systems to manage, operate and rehabilitate their water distribution networks. This survey found that while GIS's are being used by many cities to manage their assets, the level of complexity regarding the type of data stored varies widely. Very few organizations were found to completely rely on a GIS based system to store, maintain and retrieve records but the trend is heading that way. It was also found that GIS's have been successfully used as tools to plan and prioritize water main rehabilitation programs. The second part of the paper presents the results of the spatial analysis. It was found that, based on the AWWA soil corrosiveness scoring system, the majority of the soil samples taken from the district of Etobicoke are considered to be "corrosive" towards castiron. With one exception, all of the soil samples taken from the district of Etobicoke had resistivities lower than $2000 \Omega \cdot \mathrm{cm}$. Since low soil resistivity increases the risk for external corrosion, Etobicoke's water mains are potentially at greater risk than those located in the district of Toronto. Water mains located in the district of Etobicoke have experienced higher external pitting rates and show more evidence of external corrosion than do water mains located in the district of Toronto. Generally, water mains in the City of Toronto are not at risk for deterioration due to sulphate reducing bacteria. However, there is some evidence indicating that water mains in the northern part of the district of Etobicoke are potentially at increased risk for microbiological corrosion. Additional investigations are needed to confirm this. 


\subsection{Introduction}

As water distribution networks age, the deterioration of water mains due to external corrosion becomes more and more of a concern. Recognizing that this is potentially a major problem, the City of Toronto contracted the University of Toronto to undertake an investigation into the condition of the city's water distribution network. The city hoped that through this project it would be better able to focus its rehabilitation efforts by having a more complete understanding of the causative factors behind water main deterioration.

Over the course of this project a number of pipe and soil samples were collected from locations across the City of Toronto. The collected pipe samples were tested for mechanical strength and examined for evidence of internal and external corrosion. The soil samples were tested for properties ( $\mathrm{pH}$, resistivity and evidence of sulphate reducing bacteria) identified as having an influence on external corrosion.

In another paper (Doyle and Grabinsky 2000), it has been described how the data gathered during this investigation was analyzed using traditional methods. Statistical models were applied to the dataset to look for correlations between the external rate of corrosion and the various soil properties. Some evidence was found which indicated that resistivity was the soil property which best predicted the maximum external pitting rate.

However, after analyzing the information in that manner the following questions still remained:

- Based on the available data, which areas of the distribution network showed the most evidence of corrosion?

- Were there any correlations between geographic location and the amount of external corrosion?

- Based on the available data, could it be determined which parts of the network are potentially most at risk for external corrosion in the future?

- If corrosion relates to a certain soil property, can we map out those soil locations and identify the pipes at risk?

It was recognized that a spatial analysis (linking the data collected during the project to geographic location) was necessary to answer these questions. It was decided that this could be best accomplished by inputting the data into a Geographic Information System (GIS).

This paper consists of two parts. In the first section it will present examples of how other cities and utilities are using GIS's to manage their infrastructure and plan water main 
rehabilitation programs. It will also look at some of the emerging trends in how GIS's are being used to share information. Specifically, how organizations are taking advantage of the Internet to provide wider access (both to the public and their employees) to their GIS's. This is done to provide context about the problems facing utilities and justify the application of a GIS to analyze the data collected during this study. The paper will then present an overview of the City of Toronto water main investigation and briefly explain how the various soil properties influence the external corrosion rate and how this study tested for them. Finally, it will describe the GIS created during this investigation and present the results found when it was used to spatially analyze the collected data.

\subsection{GIS}

A GIS has been defined as "a system for capturing, storing, checking, integrating, manipulating, analyzing and displaying data which are spatially referenced to the earth" (Musgrave 1996). It is the process of spatially referencing data that sets GIS apart from other database management tools.

\subsubsection{The Use of GIS by the City of Toronto}

At present, the use of a GIS by the City of Toronto to manage its infrastructure has been limited. Efforts are underway to update how the city manages its assets but there are a number of hurdles to be overcome. Presently the city is "migrating all the sewer and water main data over [to] a new data model. The data model is MIDS which stands for Municipal Infrastructure Data Standard. Once all the data is migrated over we will resolve or try to [resolve] all deficiencies." (Klimas, pers. comm 2000). MIDS was designed by the Ontario Good Roads Association (OGRA) and is an attempt to create a standard data model to be used by all cities in Ontario.

Originally, Metropolitan Toronto consisted of six separate cities. Each city had a Works and Emergency Services Department responsible for operating and maintaining the infrastructure within that city's boundaries. In 1998, Metro Toronto was dissolved and the six cities were amalgamated into the City of Toronto. This necessitated the creation of a single Works and Emergency Services Department for the entire city which created an additional problem. Prior to amalgamation the six former cities each stored asset information (type of water main material, diameter etc..), historical performance records and maintenance data in different formats. According to Robert Klimas of the City of Toronto, "All historical data about repairs and maintenance is paper driven. Some databases were built in the former City of North York 
on maintenance. Etobicoke was the only city that kept track of these types of activities via Hansen (Hansen is computer database program designed to store records related to municipal infrastructure)." (Kilmas, pers. comm. 2000)

The challenges Toronto faces in adopting a GIS to manage its assets are not unique. As will be shown, other cities in North America have overcome similar problems and are experiencing the benefits of using a GIS. To develop an understanding of how public works departments are using GIS to manage their waterworks infrastructure a survey was conducted (a copy of the survey questions is appended to end of this paper). This survey was designed to provide a snapshot of each organization's experience with GIS. The questionnaire was emailed to approximately 125 cities and waterworks utilities in Canada, the United States and Australia. As with any survey, there was no control possible over which cities replied and how detailed they were in their answers. Some of the respondents provided very detailed answers to the questions while others only answered with a yes or no. This made the process of taking the various replies and trying to draw some general conclusion, as well as, some specific examples about how GIS's are being used a difficult process.

\subsection{Survey Results}

Out of the organizations contacted, 35 responded to the survey. A list of the cities and utilities which answered is presented in Table 3.1. There was a fairly even split between Canada and the United States. The public works departments of two Australian cities also answered the survey.

\subsubsection{Use of GIS}

Of the 35 public works departments and utilities which responded to the survey, it was found that:

- 26 are using GIS's

- 3 are not using GIS's

- 6 are in the process of implementing a GIS

Due to the "random" nature of this survey, not all of the public works departments in the cities who replied are responsible for maintaining the city's water distribution network. In these cases, attempts were made to contact the utilities responsible for the water distribution network but they were not always successful.

Of the 32 organizations using or developing a GIS, only 27 are responsible for maintaining and operating a water distribution network. 


\section{Table 3.1 - List of Cities Responding to Survey}

\begin{tabular}{l|l}
\multicolumn{1}{c}{ Canada } & \multicolumn{1}{c}{ United States } \\
\hline Barrie, Ontario & Huntsvile, Alabama \\
Durham Region, Ontario & Tuscon, Arizona \\
Guelph, Ontario & Los Angeles, California \\
Hamilton, Ontario & Denver Water, Colorado \\
Kitchener, Ontario & Cinncinnati Waterworks, Ohio \\
Kingston, Ontario & Buffalo, New York \\
Newmarket, Ontario & Las Vegas, Nevada \\
Pickering Ontario & Pawbucket Water Supply Board \\
Richmond Hill, Ontario & Houston, Texas \\
Toronto, Ontario & Abilene Water Utilities, Texas \\
Windsor, Ontario & Cheasapeake, Virginia \\
Lethbridge, Alberta & Norfolk, Virginia \\
Calgary, Alberta & Seattle, Washington \\
Winnipeg, Manitoba & Spokane City, Washington \\
Saskatoon, Saskatchewan & \\
Kamloops, BC & Adelalde, South Australla \\
Victoria, BC & Melbourne, Victoria \\
\hline
\end{tabular}

\subsubsection{Length of Time Using GIS}

The concept of spatially analyzing data has been known for almost four decades. However, the ability for individuals and small organizations to apply the concepts (in terms of technology) has existed for the last 20 years and really for the last 10 with the widespread adoption of powerful desktop computers. Only with the development of PC based GIS application (by major vendors such as ESRI and Intergraph) and the widespread adoption of desktop PC's has the use of GIS become widespread.

This survey found that the use of GIS by the organizations contacted varies widely. The city of Denver, Colorado states that they have been using GIS since 1983. The city of Saskatoon, Saskatchewan has been using it since 1980. At the opposite end of the spectrum, cities such as Buffalo (New York), Barrie (Ontario) and Windsor (Ontario) are just beginning to implement a GIS system. Of the 32 cities which are presently using GIS (or in the process of implementing one) their experience with it is as follows:

- Less than 1 year

- 1 - 5 years

- 5-10 years 14

- Over 10 years 2 
In light of the fact that it was in the 1990's that personal computers became relatively affordable, it makes sense that the majority of the organizations have only begun to use GIS in the last 10 years.

\subsubsection{Detail of the Data Available Through the GIS}

At its most basic level a GIS only contains a map or maps. In the case of a city's water distribution network these maps could consist of the location of the pipes, valves, fire hydrants etc. What makes a GIS so useful is the ability to attribute data to these maps as separate layers. In addition to knowing the location of a piece of the infrastructure it is possibie to attach information about the characteristics of the structure (such as age, material, repair history, etc.)

The survey sent to the different organizations inquired about the detailed level of the information available through their GIS. As with the other survey items, the replies varied from a verbose description of what can be accessed to a not applicable (in the situations where the GIS is still being built). To provide a basic overview of the survey results, the replies from the 27 organizations responsible for maintaining a water distribution network have been grouped into the following categories:

Category 1 - Fully enabled GIS (maps linked to detailed databases about the pipeline network)

Category 2 - Building the links between the Maps and the databases

Category 3 - Mapping only/or still building database (in the processing of digitizing records,etc.)

It is recognized that these are very broad and somewhat subjective categories into which to group the responses from the survey. Nonetheless, this is the best way to provide a snapshot of what is happening. According to the survey, of the 27 organizations responsible for the waterworks 11 can be grouped into Category 1 (see Table 3.2). 
Table 3.2 - Cities Grouped by the Detail of the Data Available Through Their GIS

\begin{tabular}{|c|c|c|}
\hline category 1 & Cagegry 2 & calegory's \\
\hline $\begin{array}{l}\text { Calgary. Alberta } \\
\text { Denver, Colorado } \\
\text { Winnipeg, Manitoba } \\
\text { Cincinnati Waterworks, Ohio } \\
\text { Kitchener, Ontario } \\
\text { London. Ontario } \\
\text { Richmond Hill, Ontario } \\
\text { Houston, Texas } \\
\text { Knoxville, Tennessee } \\
\text { Chesapeake City, Virginia } \\
\text { Seattle, Washington }\end{array}$ & $\begin{array}{l}\text { Adelaide, Australia } \\
\text { Guelph, Ontario } \\
\text { Hamilton, Ontario } \\
\text { Kingston, Ontario } \\
\text { Saskatoon, Saskatchewan }\end{array}$ & $\begin{array}{l}\text { Funtsvile, Alabama } \\
\text { Lethbridge, Alberta } \\
\text { Tuscon, Arizona } \\
\text { Kamloops, B.C. } \\
\text { Barrie, Ontario } \\
\text { Durnam Region. Ontario } \\
\text { Toronto, Ontario } \\
\text { Windsor, Ontario } \\
\text { Pawbucket Water Supply Board } \\
\text { Abilene, Texas } \\
\text { Spokane City, Washington }\end{array}$ \\
\hline
\end{tabular}

A typical example of this category would be the City of Seattle, Washington. As explained by Stephen Turalba (GISNater Supply and Treatment) Seattle's GIS has "fairly detailed data. (ie; you can find out water mains information such as size, material, date of installation, depth location, pressure, historical leaks repairs... We are also trying to integrate our work management software called "Maximo". This software database has the historical data and maintenance information records in details" (Turbla, pers. comm. 2000).

Houston, Texas" GIS can access "instaliation date, type of material, line size, depths, and about 30 attribute items on water, sanitary and storm sewers". (Hudson, pers. comm. 2000) Additionally, Houston has also integrated an "Infrastructure Management System in January, 1999 and are completing that project with ESRI. We use Azteca's City Works as a base. It is a work order system that is integrated to the GIS. We can click on a line segment and get the work order history for that item any time in the future. It is a full fledged work order system capable of capturing costs, materials and time" (Hudson, pers. comm 2000)

The City of Kitchener, Ontario has also linked a work order system with their GIS. Michelle Pape describes it as "two systems that work together through structure id numbers. The mapping/engineering data base contains all structure related information such as structid, on street, from street, to street, material, length, date installed etc. This is the data that is connected to the maps. This data is also available to the Work Management System. The database on this side contains all of the work related information plus structure info as above. We can select a structure, say a water main, and attach a work order to it, to repair a break. All info from that work order such as repair costs is then associated with the structid of the main. Eventually once Mapinfo works with the Work Management System we could produce thematic mapping based on many things such as historical data." (Pape, pers. comm. 2000) 
The Town of Richmond Hill, Ontario also falls into Category 1. Bill Joyce states that "Water data includes all primary fields from the original SIMSMIMS systems and conforms to MIDS. We are in the process of tying it to our new Maintenance Management System (Maintain) in the year 2000" (Joyce, pers. comm. 2000).

The term MIDS refers to the Municipal Infrastructure Data Standard established by the Ontario Good Roads Association (OGRA). MIDS is an attempt to establish a set of standards regarding the type of data that municipalities (and other utilities) should keep about their infrastructure. A different set of standards has been established for water, sewers, road etc. A detailed explanation about MIDS is available on the OGRA website (www.orga.com).

Only 5 utilities fit into Category 2. They have a GIS that contains some information about the water distribution network but are still in the processing of linking up additional databases. For example, Saskatoon, Saskatchewan is "beginning to connect their historical water data to the entities" (Fishley, pers. comm. 2000). The same situation can be found in Adelaide, Australia. According to Bob Shields (Senior GIS Officer) some data has been entered but "at this moment the historical data is rather sketchy and is in the process of being built up". (Shields, pers. comm. 2000) The town of Guelph, Ontario has some data available through their GIS and is "currently linking our Maplnfo spatial data to our maintenance management system which is the repository for work orders, asset maintenance history etc" (Ross, pers. comm. 2000).

Eleven organizations fit into category 3 . Their GIS's are still largely in a data capture mode. The records and maps which will form the databases are still in the process of being organized into the proper formats. For example. Spokane City's water department has "not converted their infrastructure yet, but began limited use of GIS about a year ago." (Hendron, pers. comm. 2000) Abilene, Texas has digitized maps of their water system available through their GIS but historical data about water main repairs or work-orders are "not (available) at this time". (Simpson, pers. comm. 2000)

Victoria, B.C. is also in the process of developing a GIS. Presently GIS use is limited. No historical information about the water network is available. Alan Mallett (pers. comm. 2000) describes the system as "essentially static at this time. We are just completing the mapping part of the water system, and there is some basic data in MSAccess that we will attach soon". Lethbridge, Alberta is also beginning to implement their strategic GIS plan. Their goal is to "remove an older system of valve, hydrant and service connection cards which are used to 
track maintenance and through Cartegraph create a "paperless" maintenance records system." (McDonald, pers. comm. 2000)

To be useful for daily operations the databases accessed by the GIS must also be kept current. If this does not happen users will revert back to the traditional way they stored data (paper maps, card files etc.) and the GIS will die from lack of use. The majority of the 27 groups using a GIS to maintain their water distribution network stated that they update their databases daily, weekly or "frequently". By keeping the databases dynamic instead of static users are encouraged to keep using the system because it contains the most current information.

\subsubsection{GIS and the Internet}

After creating the GIS the next step is deciding how to distribute the information it contains. The ability of users to easily access the information stored in the GIS is a key factor in its success. Until recently distributing and remotely accessing the data stored in a GIS could be a difficult problem. Recent developments are starting to change this situation. They are: 1) The internet (specifically the World Wide Web); 2) The development of GIS internet based applications.

By using the internet it is possible for users to remotely access the data stored in a GIS. This has only become possible in the last few years with the development of software that allows a GIS to be viewed over the World Wide Web. Products such as ArcExplorer and MapObjects from ESRI and MapGuide from Intergraph allow users to use a PC to connect with a GIS and query the information stored in the system using a standard web browser (Microsoft Explorer or Netscape Navigator).

The system works on a client-server basis. The programs are browser plug-ins that need to be downloaded prior to using them. After the programs are installed in either Netscape and Explorer the user is then able to view the GIS on the remote computer and make simple spatial queries. It is also possible to obtain similar results without using ready made programs. Cities such as, Markham and Kitchener, Ontario have made their databases available through a standard web browser and some custom designed Java and ActiveX applications (Hodgson, GIS2000 Conference). 
The advantages to this technology are:

1) It uses established protocols to transmit the information (TCP/IP) and on the client side uses browser software widely available.

2) It has an easy learning curve. Most people are familiar with browsing on the web.

3) It reduces the amount of duplication because all of the information is stored in a central database. No information is stored on the client computers.

4) It has scalable access. Through the use of password protection, or other means the information can be made available to the general public or just to specific users.

Out of the 32 organizations using a GIS, only 10 stated that they are using the Internet (or an Intranet) to provide access to it. Another 3 stated that they are in the process of developing such applications. The majority of the organizations who replied "No" to "Internet/Intranet" access did state that they intend to develop such applications in the future.

Most of the cities which replied "Yes" only ailow access to their data through an Intranet. One exception is the city of London, Ontario. London uses the Web to provide access to its GIS data. According to John Bontje (GIS coordinator for London) the "public and staff use the same homebuilt platform, with staff able to see more layers, eg. water \& sewer maps \& data" (Bontje pers. comm. 2000). The website can be found at http://www. city.london.on.ca.

The Town of Markham is an excellent example of how finding a way to efficiently distribute the data and maps stored in a GIS can revitalize a GIS effort. In a presentation at the GIS2000 conference in Toronto, John Hodgson from the town of Markham described how the town was until recently "mired in a data capture mode" (Hodgson, 2000). In order to break out of this mode they decided to centralize all of the data collected by the different works departments in a "spatial data warehouse" and put it on the web in a format that allowed access through a simple browser interface. Through this process they discovered that they had a lot more data collected than they realized. The problem was putting it to use by getting it to the proper people. The end product, which was demonstrated, allows the user to access the data over the city Intranet using a browser. The user can pull down a list of the available maps and perform simple spatial operations. If the map being viewed has linked data to it the user can view that as well.

It appears that putting the data on the web is an emerging trend. The cities that have done so appear to be very pleased with the results. By making the information available to the 
largest number of people possible they have added "value" to the GIS. Making sure it doesn't remain a closed system, limited to just managers and trained technicians, ensures that the GIS will be more widely accepted and staff won't ignore it and stay with the old ways of maintaining the databases.

\subsubsection{Advantages Found Using a GIS}

The organizations which have a well developed and deployed GIS appear to be benefiting from its use. According to Ken Dalton of the City of Winnipeg. Manitoba: "It has definitely given us immediate access to fairly accurate underground infrastructure data, which has equated to significant time savings. It has also greatly improved our asset management, particularly in regard to our water network. We can analyze our systems, in terms of leak frequency, etc., in a very short time frame. By making this data available to a large number of staff it has significantly reduced the pressure for the staff of my branch in supplying infrastructure information." (Dalton, pers. comm. 2000)

These thoughts are echoed by Ray Fishley. of Saskatoon, Saskatchewan. He says that "I believe the City of Saskatoon has gained from using GIS. We are able to put detailed geographically based data into the hands of key decision makers. Because of GIS we are able to do a wider variety of analysis and modeling. We have given more people access to data than they ever had before. Because of this wider dissemination of corporate GIS data, we have improved data integrity. These are only a few of the benefits of GIS". (Fishley. pers. comm. 2000)

Bill Joyce of the town of Richmond Hill mentions an advantage the GIS gives to the field crews: "Amongst its many attributes it performs one main objective - crews leave the shop with the tools, clamps, etc. that they need and they know exactly where they are going". (Joyce, pers. comm. 2000)

\subsubsection{The Application of GIS's to Water Main Maintenance and Rehabilitation}

To be of any engineering value the information stored in the GIS has to be put to use. If the GIS is being treated only as a static repository for data about the system then it is not reaching its full potential. Many cities are using their GIS's to monitor water main breaks, predict which areas are most at risk and then use the data stored in the GIS to make rehabilitation plans. By having all of the data available and correlated an informed decision can be made about what to do. 
In the area of monitoring water main braaks the City of Houston, Texas has experienced tremendous savings in time and effort through the use of their GIS. The city tracks all water main breaks by location and time. Before the introduction of the GIS this information was manually plotted on paper utility blockmaps. These maps would get lost, torn and need to be replaced. This would necessitate all of the information being transferred onto new maps. There was also the problem that there was no standardization in the information that was being collected. Now that a GIS is being used these problems have been eliminated. All of the water main break locations are entered weekly into the GIS and the "output maps and data have uniform symbology" (Ron Hudson, pers. comm. 2000).

The City of Saskatoon, Saskatchewan also plans to use their GIS to plan rehabilitation efforts. According to Ray Fishiey, "We have length, material, size, (and) year of installation captured for the entire water network and are beginning to connect our historical water data to the entities. We plan on using this (along with other data) to justify and create a replacement program" (Fishley, pers. comm 2000.).

The City of Los Angeles, California Department of Water and Power is another example of how a GIS is being used to plan water main rehabilitation efforts. The LADWP has "utilized GIS technology along with a combination of in-house maps and records to create a comprehensive (water main) replacement program" (Stern 2000 ).

Not only are GIS's being used to store information and plan rehabilitation efforts based on historical data, they are also being combined with statistical models to predict which areas of the distribution network are most likely to be at risk in the future. One city doing this is Seattle, Washington. In order to identify water mains in need of maintenance and rehabilitation a statistical program (Pipe Evaluation System (PIPES), Weston inc.) has been combined with the data about the water mains stored in the city's GIS. A paper on this project (Bodner, Lim 1999) states that "water engineers and managers have seized upon the advantages of accessing water main characteristic information through Seattle's GIS and have significantly reduced the time spent identifying and prioritizing water mains for preventative maintenance, rehabilitation or replacement".

In order to make these decisions "a custom decision-support application was developed to leverage the GIS water main characteristic data with statistically based decision models to improve decision making. Correlation of water main characteristics with time-to-failure factors identified statistically significant failure prediction indicators. Based on the identified 
indicators, decision models were developed for evaluating deterioration, vulnerability and service criticality factors". The results of these models were used to prioritize water main replacement or rehabilitation efforts.

The GIS was critical to accomplishing this task. It's stated that "the whole evaluation process rests on the GIS analysis and data processing to provide all the attributes of the pipelines as well as to find spatial relationships to other layers of information."

Having described how organizations across North America are using GIS's to manage the assets of their water distribution networks and plan water main rehabilitation programs, this paper will now present the results of the City of Toronto water main investigation. This includes a description of the problem and a brief explanation of how the various soil properties effect the rate of external corrosion and how they were tested during this study. The results of GIS analysis will then be presented.

\subsection{Study Methodology}

The City of Toronto maintains and operates $5347 \mathrm{~km}$ of local water mains (average diameter of $150 \mathrm{~mm}-300 \mathrm{~mm}$ ) and $487 \mathrm{~km}$ of trunk water mains (Klimas, pers. comm. 2000). The majority of the network consists of grey cast-iron and ductile cast-iron pipes. The oldest parts of the system are located in the downtown core with pipe age decreasing towards the periphery of the city. Pipe samples encountered in this project ranged from 30 to 120 years old.

The surficial stratigraphy of Toronto was formed as a result of the last ice age. As such, the majority of the surficial soils in which the water distribution network is laid consist of clayeysilty tills formed by glaciers or sand and clay deposits created by extinct glacial lakes (such as Lake Iroquois and the Peel Ponds). Clays and silts have properties (such as low resistivity, more suitable for the growth of sulphate reducing bacteria) which make them more corrosive towards cast-iron water mains than soils such as sands and gravels. Therefore, simply based on the pre-existing conditions the surficial stratigraphy of the Toronto area potentially puts the water distribution network at increased risk for deterioration. The research conducted during this study will begin to quantify that risk.

All six districts comprising the City of Toronto were invited to partake in this project. A total of 108 pipe and 98 soil samples were collected during this study. The majority of the samples came from the districts of Toronto and Etobicoke. Only 8 samples came from other districts. 
Of these, 6 came from the district of North York and 2 from the district of Scarborough. All but three of the pipe samples received were pit or spun cast grey iron. The remaining three were ductile iron. Unfortunately, the locations couid only be determined for 79 of the samples. This limited the amount of data available for use in the GIS.

The soil samples were tested for resistivity, $\mathrm{pH}$ and sulphide content (which indicates the presence of sulphate reducing bacteria). The properties all have been identified as influencing the rate of external corrosion. The pipe samples were examined for evidence of external corrosion. The following section provides a brief overview of the how each soil property can affect the external corrosion rate and describes the experimental procedures used to test for those properties. These items are described in detail in Chapter 2 and are repeated here for completeness.

\subsubsection{Classification of Soil Samples}

Classification of the soil samples was done according to the ASTM D2488 standard. This standard identifies soils through simple visual-manual tests and classifies them as silts, clays, sands and gravels.

\subsubsection{Soil Resistivity}

When corrosion is electrochemical in nature, soil resistivity plays a major factor in determining the corrosion rate. Generally, the lower the resistivity of the soil the higher the external corrosion rate of the pipe. Typically, because of the high ion content of their porewater, clays have the lowest resistivities while sands and gravels have the highest. The "natural" resistivity of a soil can be modified by the presence of additional ions in the porewater (for example from contamination by road salt). This is an area of potential concern as the City of Toronto applies large amounts of road salt during the winter months.

The resistivities of the samples were determined in a laboratory setting using the Wenner four-electrode method (ASTM G57 standard). The samples were placed into a soil box which had two outer and two inner electrodes. A constant voltage of $12 \mathrm{~V}$, supplied by a Hewlett Packard E3612A direct current power source, was applied to the outer electrodes and the current and voltage drop across the inner electrodes was measured using a digital multimeter. The readings were recorded when the values reached equilibrium. 


\subsubsection{Soil pH}

The $\mathrm{pH}$ level of the soil can directly and indirectly affect its corrosivity. If the $\mathrm{pH}$ is from 0.0 to 4.0 the soil is acidic and can directly corrode the cast-iron. An investigation into the relationship between total acidity and corrosion found that the rate of corrosion was proportional to the total acidity of the soils (Denison and Hobbs 1934). A low pH also means that the soil is a good electrolyte because more hydrogen ions are available to act as electron acceptors (AWWANANSI C105/A25.5-99).

Soils with a higher $\mathrm{pH}$ have an indirect effect on water main deterioration. If the $\mathrm{pH}$ is between $5.5-8.5$ the soil is suitable for the growth of sulphate reducing bacteria. If the $\mathrm{pH}$ is greater than 8.5 soils are high in dissolved salts lowering soil resistivity (AWWAVANSI C105/A25.5-99).

The pH's of the soils were measured in accordance with the ASTM G51 standard. Ten grams of soil were mixed into a $500 \mathrm{ml}$ flask with $90 \mathrm{ml}$ of distilled water. The sample was allowed to stand a few minutes to allow any soluble salts to dissolve. The pH value of the soil sample was measured using a pH meter and recorded when the reading reached equilibrium.

\subsubsection{Soil Sulphide Content}

If a soil has a high sulphide content it is an indicator of the presence of sulphate reducing bacteria. While it is agreed that these bacteria cause iron to corrode there are different theories about the causative mechanisms. One theory (originally Kuhr and Vlught 1934; found in Iverson 1984) is that the sulphate reducing bacteria depolarize the cathode by removing the hydrogen film which had formed on it maintaining the corrosion rate over time. Another theory (Iverson 1984) is that the bacteria release a corrosive metabolic byproduct which directly corrodes the water main.

The sulphide content of the soil was found by mixing a soil sample with water and $\mathrm{HCl}$ acid in a sealed beaker. The concentration of $\mathrm{H}_{2} \mathrm{~S}$ gas released by the $\mathrm{HCl}$ acid was measured and using a formula converted into $\mathrm{mg}$ of sulphide per kilogram of dry soil (a detailed description of the procedure and the conversion formula is found in Seica et al. 2000). 


\subsection{GIS Description}

The GIS used in this study was created with ArcView 3.1 (ESRI) and consisted of three layers:

\subsubsection{Layer 1 - Geocoded Centre-Line Street Map of Etobicoke and Toronto}

A geocoded map (see Figure 3.1) was necessary in order to use ArcView's address matching capability. In a geocoded map each street is broken down into segments. Attached to each segment are the high and low house numbers for the right and left sides of the street. ArcView uses this information to accurately locate addresses on a map. The location of each pipe and soil sample was plotted using this feature.

As previously mentioned, soil and pipe samples were obtained from locations across the City of Toronto. Unfortunately, a geocoded map was available only for the districts of Toronto and Etobicoke. However, since the majority of the samples came from those districts this was not considered a problem and only the data from those two districts was used in the GIS analysis.

\subsubsection{Layer 2 - Sample Locations and Attributed Data}

The locations were known for 79 of the pipe and soil samples supplied by the city. Each location was plotted onto the street map using ArcView's address matching capability (see Figure 3.2). Attributed to each location was the data about the soil properties and the external corrosion of water main section collected during this project. This data was stored in the dBase IV (Borland, Inc.) format.

\subsubsection{Layer 3 - Surface Soil Map of Toronto and Etobicoke}

A surface soil map of Toronto was created in ArcView and saved as a theme (see Figure 3.3). This map was created by the author and is based on Ontario Geological Survey Map 2204 "Quaternary Geology - Toronto and Surrounding Area". A surface soil map was included because it provides a general idea of the soil surrounding the water mains in a particular area. This map identifies the soil formations closest to the surface. The thickness of these soil formations are generally greater than the depth at which water mains are buried (approximately $2.5 \mathrm{~m}$ ) making this soil map a valid tool. Knowing if a soil is a clay or a sand gives an immediate idea of the amount of corrosion a water main might experience. 
Figure 3.1 - GIS Layer 1 - Geocoded Centre-line Street Map of Toronto and Etobicoke

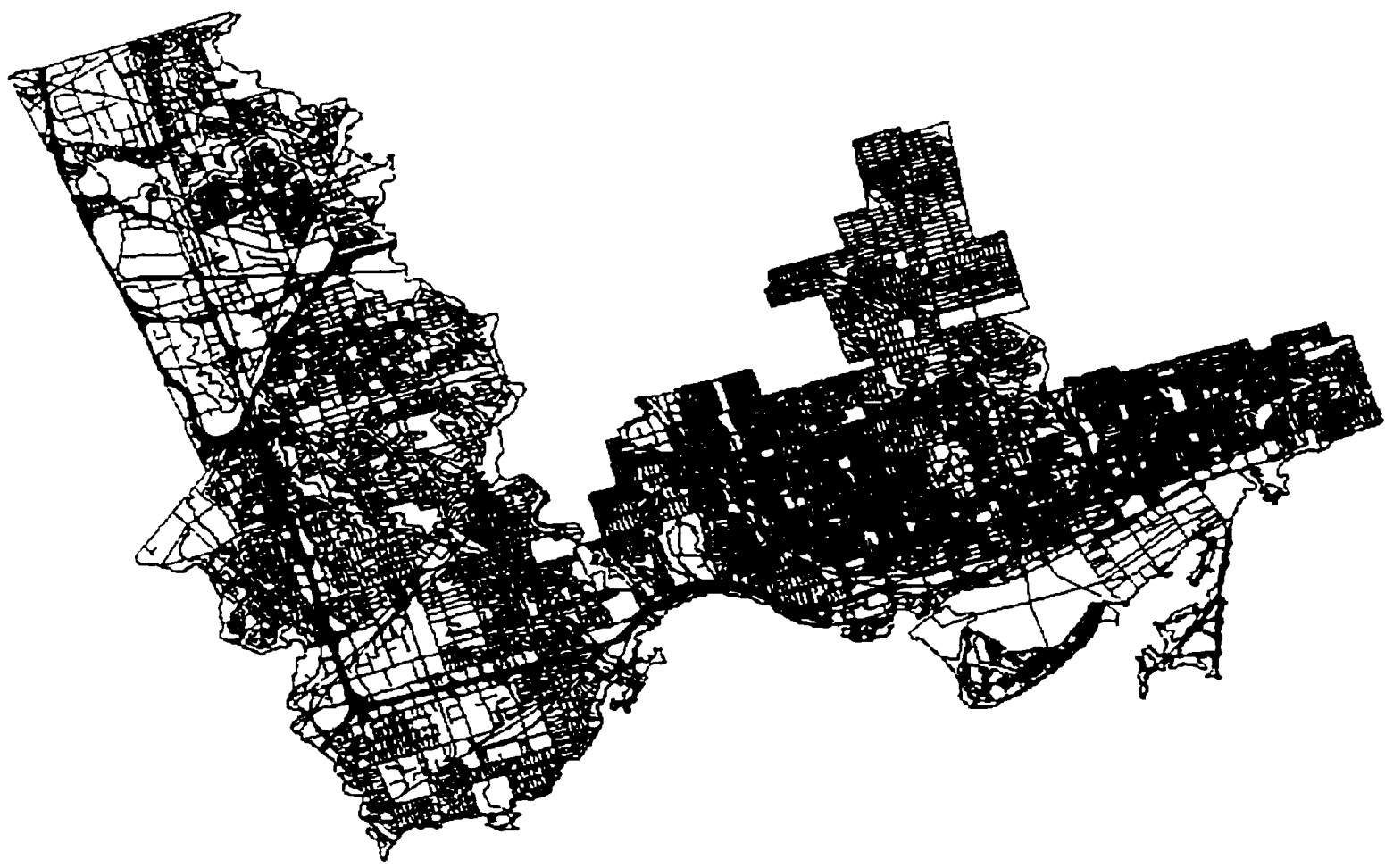

Figure 3.2 - GIS Layer 2 - Sample Locations and Attributed Data (Superimposed on Layer 1)

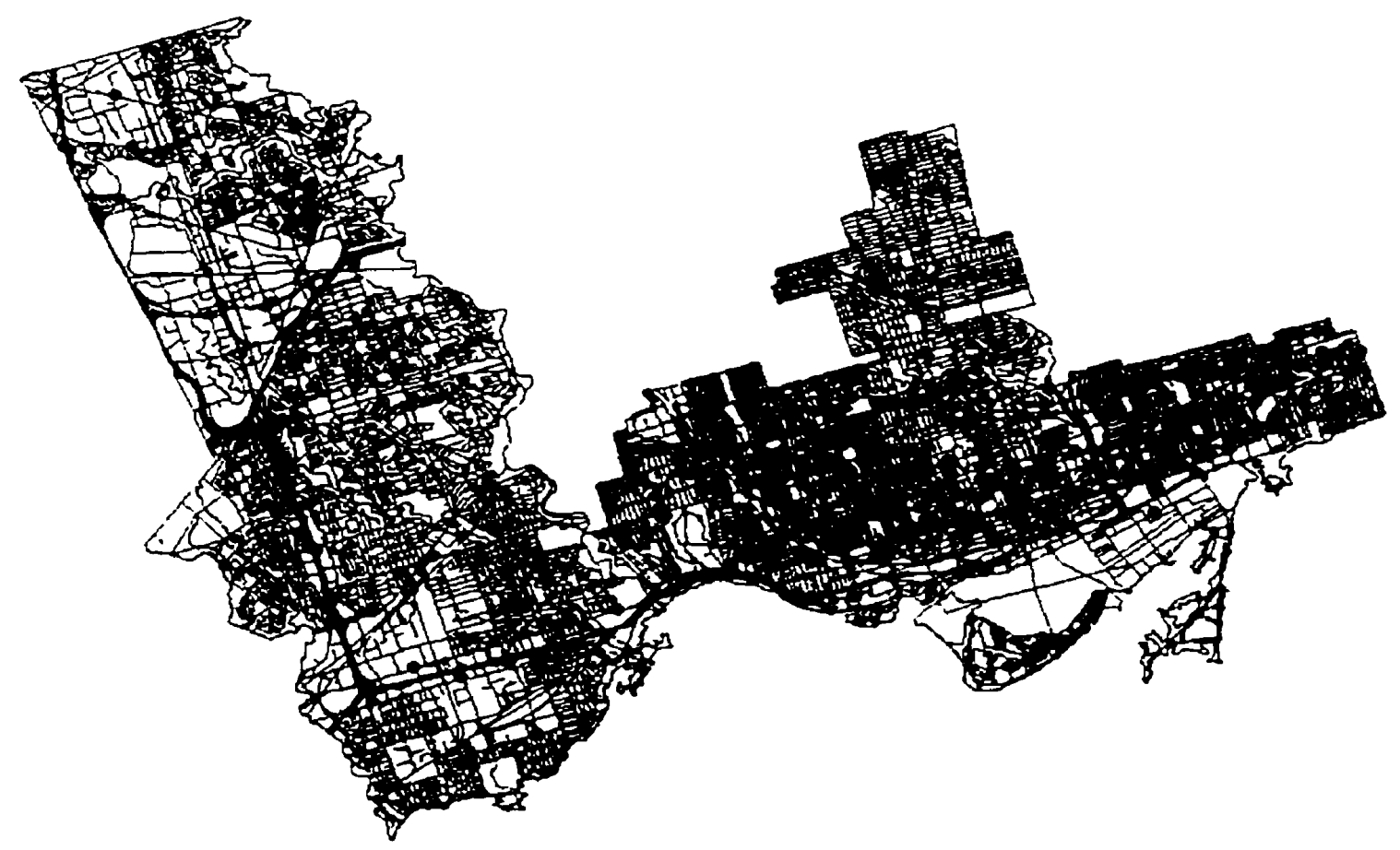




\section{Figure 3.3 - GIS Layer 3 - Surface Soil Map of Toronto and Etobicoke}

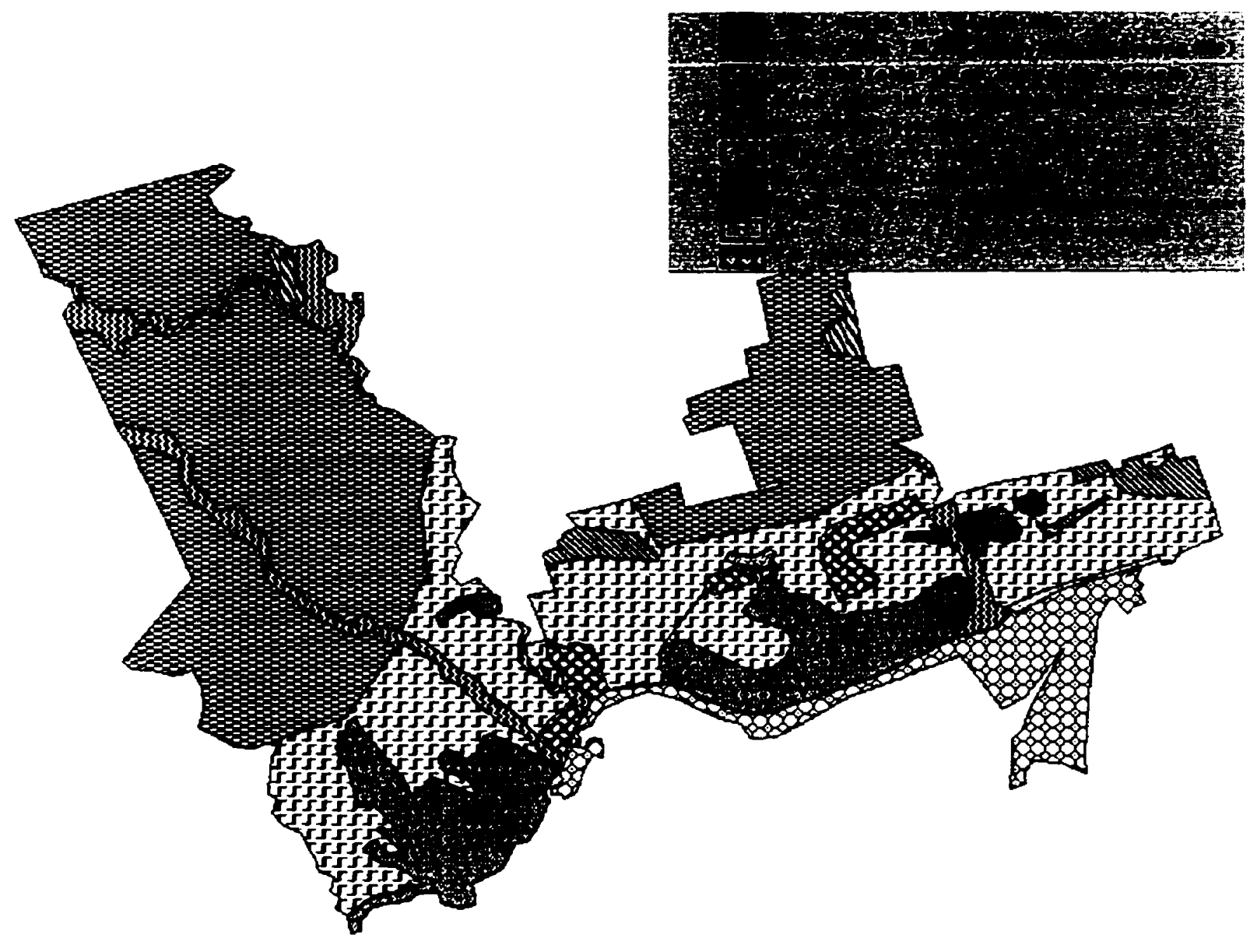

\subsection{Analysis/Discussion of Results}

Using the GIS, a spatial analysis of the data collected during the course of this research project was performed. Each of the soil properties (resistivity, pH and sulphide content) and the data describing the external corrosion of the water main samples were plotted onto the soil map and onto the city street map. The goal of plotting the data onto the street map was to identify any spatial trends regarding the collected data. For example, to determine whether the samples with high sulphide contents all came from the same area.

One limitation of the GIS used to perform this spatial analysis was the soil map. As explained, this soil map was very general in detail and identified only the large surface soil formations. Also, other than soil type, this map contained no other data. Prior to this project, no database containing information regarding soil resistivity, $\mathrm{pH}$ and sulphide content existed 
(or was at least available in the pubiic domain). For these reasons the soil map should not be used to perform any detailed analysis.

The creation of this GIS is the first step in developing a database about those soil properties which affect the rate of external corrosion. It is believed that such a database when combined with an accurate soil map would be a useful tool for predicting which areas of the distribution network are subject to aggressive soil conditions. A final product would consist of an accurate soil map; attributed to each soil formation would be information concerning the soil's resistivity. $\mathrm{pH}$ and sulphide content and any other factors which may influence the external rate of corrosion.

As the first step towards creating such a product the soil data collected during this project was plotted onto the soil map. This was done to determine if any of the soil formations had consistent properties. For example, to see if all the samples taken from a specific soil formation had low resistivities. Because only limited data was available at this time only very general conclusions can be drawn but eventually when a large enough database has been developed it would be possible to accurately define the properties and boundaries of a specific soil formation.

\subsubsection{Soil Type}

Based solely on the soil formations as described by the soil map in the district of Etobicoke, water mains located in the large clayey, silty till deposit in the north or in the clay/silt deposit near the lakeshore may be at greater risk for corrosion than those built in the sandy deposits. In the district of Toronto, water mains located in the clayey, silty till deposit in the north or in the pockets of clay/silt till in the downtown area would potentially be at the greatest risk for corrosion. It must be remembered though that because of their higher permeability sandy/gravelly soils are at greater risk for having their "natural" resistivities lowered due to chloride ion contamination from road salt.

Some variations between the two were noticed, but in general a good correlation was found between the classifications of the soil samples received during the study and the soil type as shown on the map. This confirmed both the validity of the soil samples' identifications and in using this surface soil map in the GIS. However, it is still recognized that this map needs to be refined with additional data to account for local variations in the soil formations before it can be an accurate tool for identifying "high risk" areas. 
One concern in using a soil map such as this to assess the risk of external corrosion is the fact that the trenches in which the water mains were laid may have been backfilled with nonnative material. It this were found to be the case it would obviate the use of a such a soil map. While present day construction practices typically specify a granular fill be used when backfilling, the results of the research project confirm that this was not the practice in the late 1800's until the mid 1900's. The soil samples collected from around the water mains ranged from clayey tills to sands to silts. In fact very few gravels were received. The leads to the conclusion that the trenches were backfilled with native material.

\subsubsection{Soil Resistivity}

Figure 3.4 shows the resistivities of the collected soil samples superimposed onto the city street map. From this figure it can be seen that, with one exception, the soil samples from Etobicoke had resistivities lower than $2000 \Omega \cdot \mathrm{cm}$. In comparison, the majority of the soil samples from the district of Toronto had resistivities greater than $2000 \Omega \cdot \mathrm{cm}$. Since, as shown by this study, low soil resistivity increases the risk for external corrosion, Etobicoke's water mains are potentially at greater risk than those located in the district of Toronto.

By superimposing the resistivity values onto the soil map a clearer picture emerges about why the resistivity values were distributed in the manner they were (see figure 3.5). As expected, soil samples from the parts of the city with surface deposits of clay and silt had (on average) lower resistivities. Samples from areas with sand or gravel deposits had (on average) higher resistivities. This can be used to further define the areas of the city in which water mains are most at risk for corrosion.

\subsubsection{Soil pH}

The $\mathrm{pH}$ of the soil samples referenced to the street map is shown in Figure 3.6. The pH values vary across the city. Plotting the data onto the soil map and the street map found no correlation evident between $\mathrm{pH}$ and location or $\mathrm{pH}$ and soil formation (as defined by the soil map). 


\section{Fiqure 3.4-Soil Resistivity Referenced to Street Map}

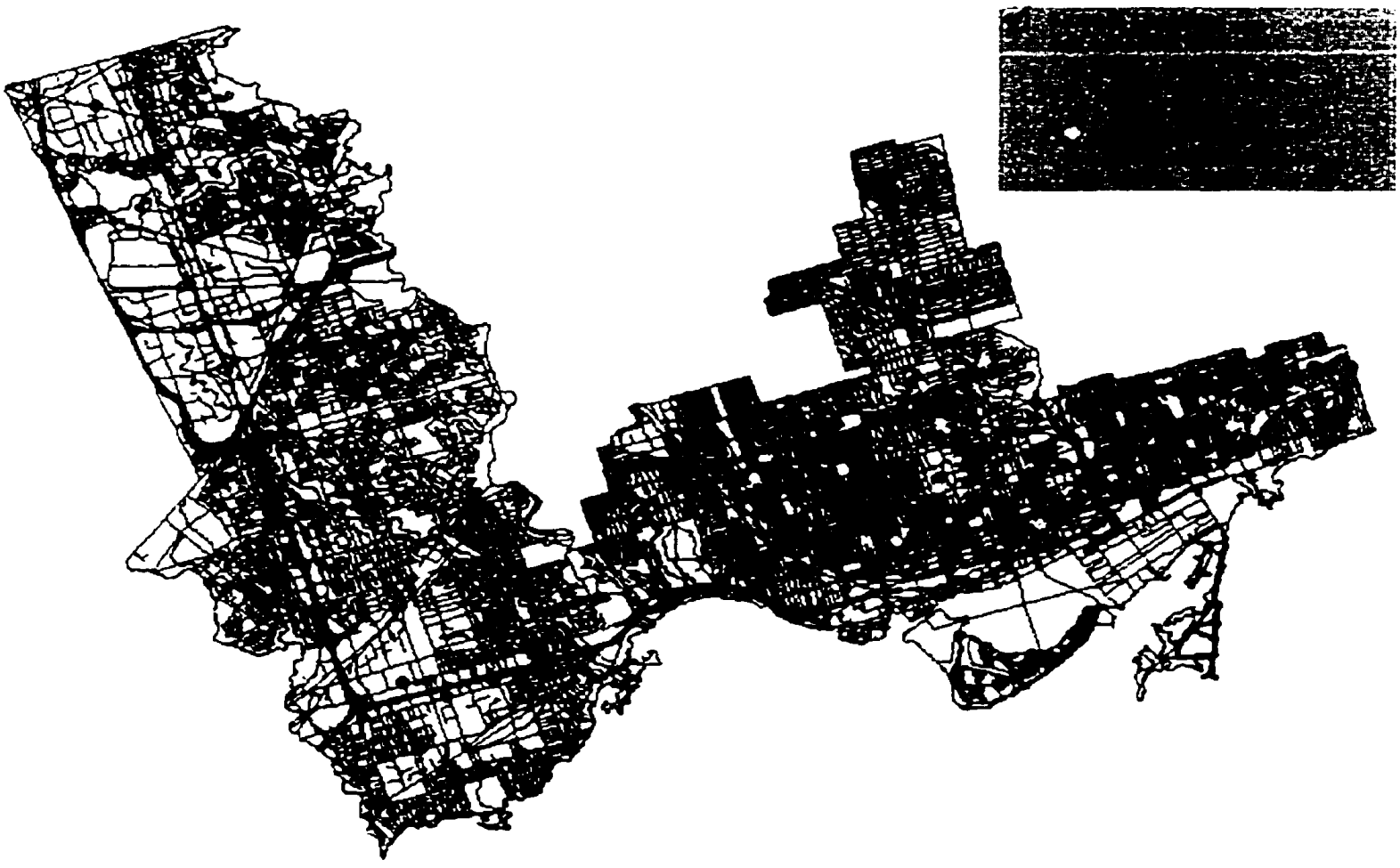

Figure 3.5 - Soil Resistivity Referenced to Surficial Soil Map

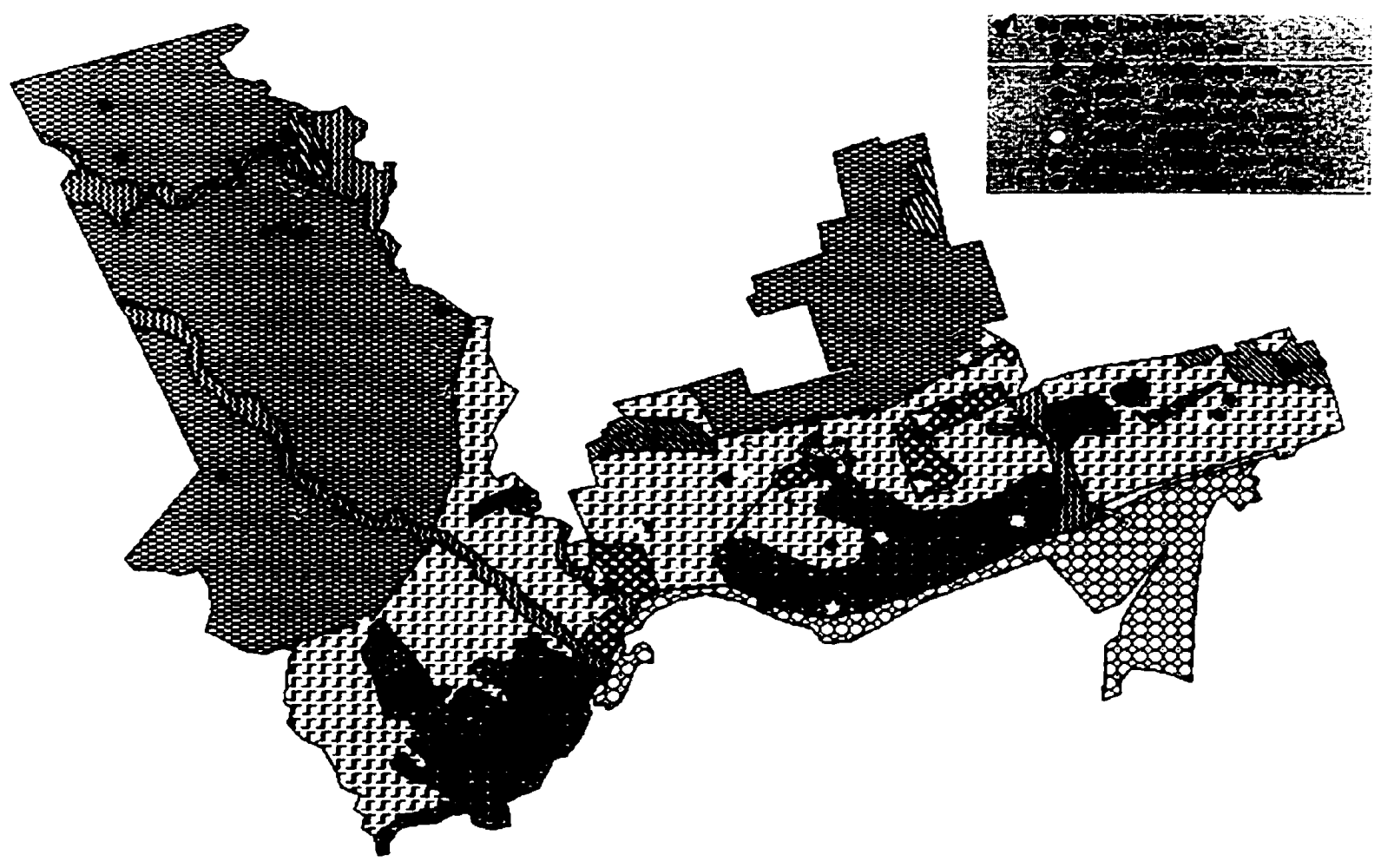




\section{Figure 3.6 - pH Referenced to Street Map}

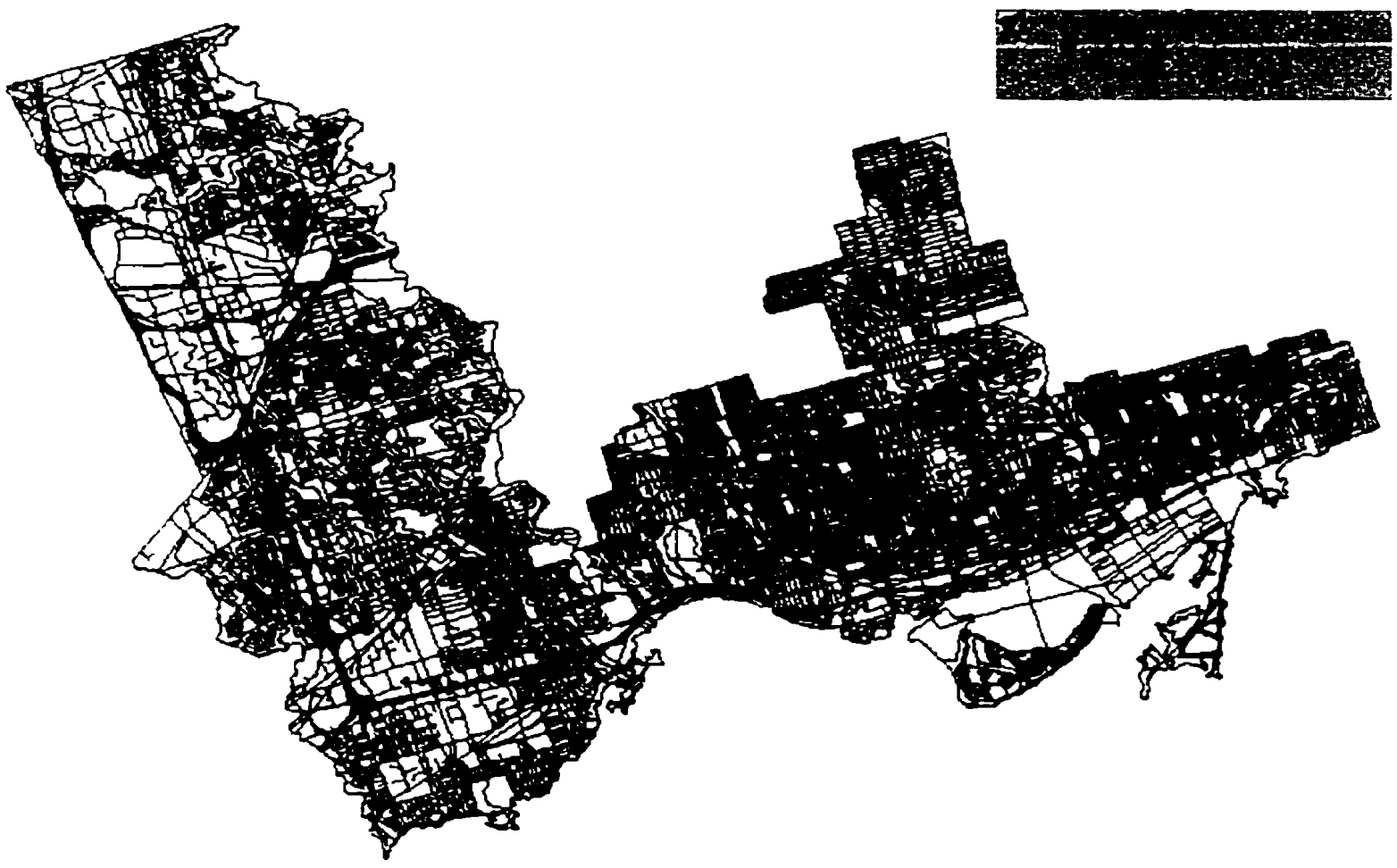

\subsubsection{Soil Sulphide Content}

The majority of the soil samples collected during this study had very low sulphide levels indicating that water main deterioration due to sulphate reducing bacteria is not a problem in the City of Toronto. As detailed in a previous paper, when the data was further analyzed it was found that pipes in soil with a sulphide concentration greater than $2 \mathrm{mg} / \mathrm{kg}$ dry soil had an average external pitting rate two times greater than those in soil with a lower sulphide content.

Figure 3.7 presents this data attributed to sampling location and plotted on the city street map. Referring to this figure it can be seen that all but two of the soil samples from the district of Toronto had sulphide contents lower than $2 \mathrm{mg} / \mathrm{kg}$ of dry soil. In contrast, twelve soil samples taken from the district of Etobicoke had suiphide contents greater than $2 \mathrm{mg} / \mathrm{kg}$ dry soil. The twelve locations are geographically disperse from one another indicating that there may be certain localized areas in the district of Etobicoke where water main deterioration due to micro-biological activity is a problem. Additional investigations are needed to confirm this. 


\subsubsection{Soil Corrosivity}

The American Water Works Association and the American National Standards Institute have established a soil corrosiveness scoring system in the standard ANSI/AWWA C105/A21.5-99. The scoring system works by assigning a point value to each of the following soil properties: resistivity, sulphide content, redox potential, moisture content. Points are assigned for each property and totaled. If the score is over 10 the soil is considered corrosive towards gray and ductile cast-iron.

The AWWA scoring system was applied to the samples collected during this study and using the GIS the results were plotted onto the surface soil map (Figure 3.8). Comparing the districts of Etobicoke and Toronto, it was found that $70 \%$ of the soil samples from the district of Etobicoke had an AWWA score greater than 10. In comparison, only $46 \%$ of the samples from the district of Toronto were classified as "corrosive". Based on these results, it is indicated that the water mains in the district of Etobicoke are at a greater risk for external corrosion due to the properties of the soil deposits in that area of the city.

\subsubsection{Maximum External Pitting Rates of Water Main Samples}

Figure 3.9 shows the maximum external pitting rates of the water main samples taken from the districts of Etobicoke and Toronto. In general, the external pitting rates of the water mains were very low. One interesting fact is that the three samples with the highest pitting rates all came from locations near the lakeshore and are in soil identified by the soil map as "fill". The two samples with the highest pitting rates were ductile iron, while the other sample was pit/spun cast-iron. Whether the high pitting rates were due to the type of water main material or because of some direct corrosive action by a chemical component of the soil is unknown. If there are buried direct current power lines in those areas the high pitting rates could be also caused by an electrolytic corrosion cell.

Comparing the maximum external pitting rates of the water mains samples taken from the two districts found that Etobicoke's water mains have generally experienced higher pitting rates than those located in the district of Toronto. Since Etobicoke's water mains are typically 30-50 years younger than those in the district of Toronto the higher observed pitting rates may be a cause for concern. Water mains in this area of the city may start to fail more frequently as time passes. 


\subsubsection{Corrosion Index}

Figure 3.10 displays the corrosion index of each pipe sample collected during the study. The corrosion index is equal to the depth of the maximum corrosion pit divided by the thickness of the pipe wall. A corrosion index of 0 corresponds to no external corrosion. A value of 1 means that the pipe wall was completely perforated. Looking at Figure 3.10, it can be seen that the sections of water main from the district of Etobicoke were generally more corroded than the samples from the district of Toronto.

However, it is important to note that this display is based on very limited data. The corrosion index number for a specific location is based on a small sample of the water main. It should not be taken as representative of the condition of the water mains over a large area. To produce a more accurate corrosion map of the city's water mains it would be necessary to take a number of pipe samples and average the amount of external corrosion over a specific water main segment.

\subsection{Recommendations}

In combination with traditional analysis techniques a GIS is a powerful tool for identifying the areas of the city where future investigations should be focused. It is also an excellent way of storing and collating the collected data for future analysis. Based on the results of this study, it is recommended that a testing program be established by the City of Toronto to continue collecting data about the properties of the soil surrounding the city's water mains. It is also recommended that a higher resolution surficial soil map be developed for the city. Such a map could be based on borehole logs the city has ready access to such as those kept by the Toronto Transit Commission.

By combining the results of the testing program with an accurate soil map it would be possible to more precisely establish the conditions affecting the city's water distribution network. A GIS containing such a database could then be used to identify the areas of the distribution network most at risk for external corrosion based on the properties of the surrounding soil. This information in combination with historical performance records and the identification of critical users (such as hospitals, schools and retirement homes) could then be used by city managers to prioritize water main rehabilitation and replacement programs. 


\section{Figure 3.7 - Sulphide Distribution Referenced to Street Map}

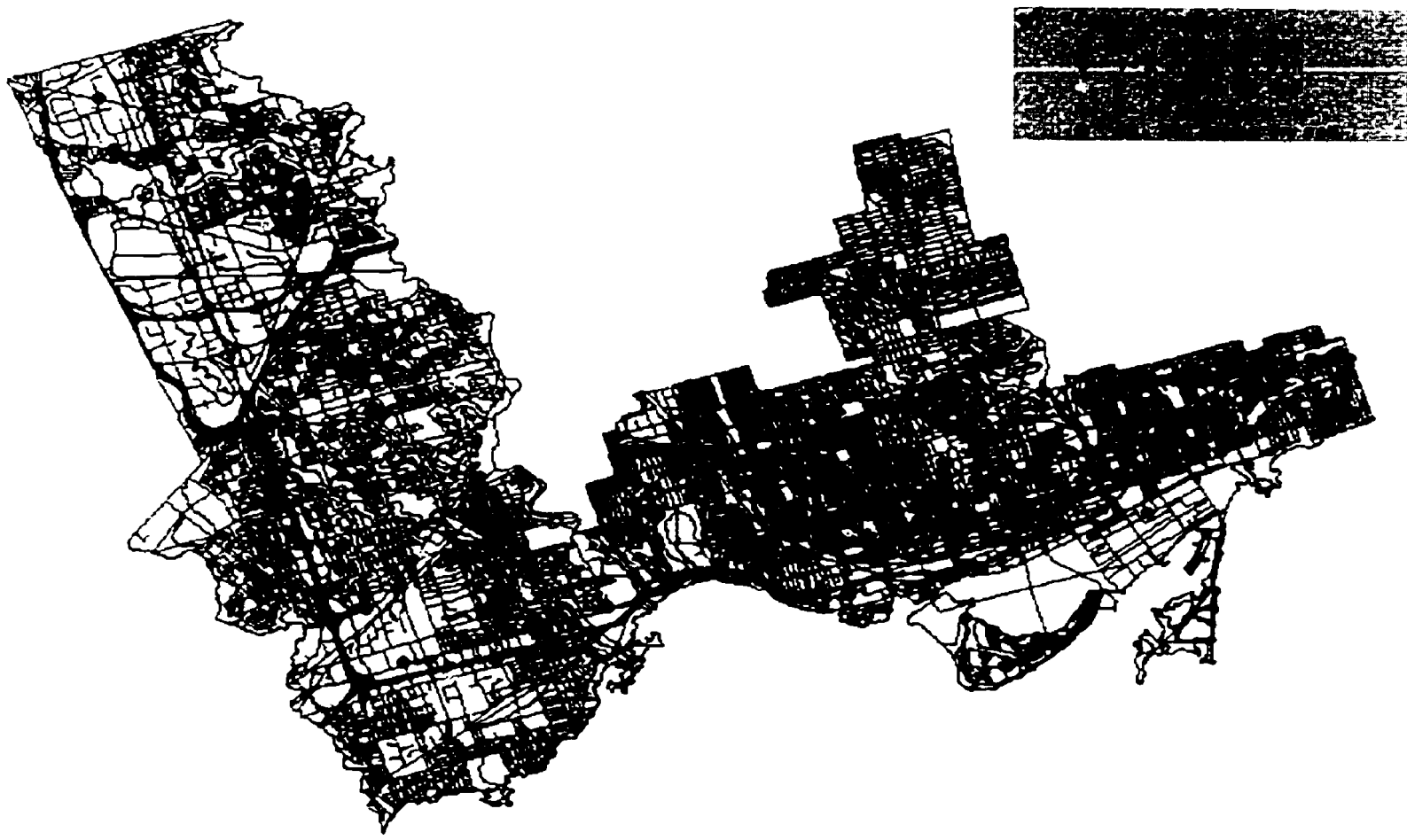

Figure 3.8 - AWWA Score Referenced to Soil Map

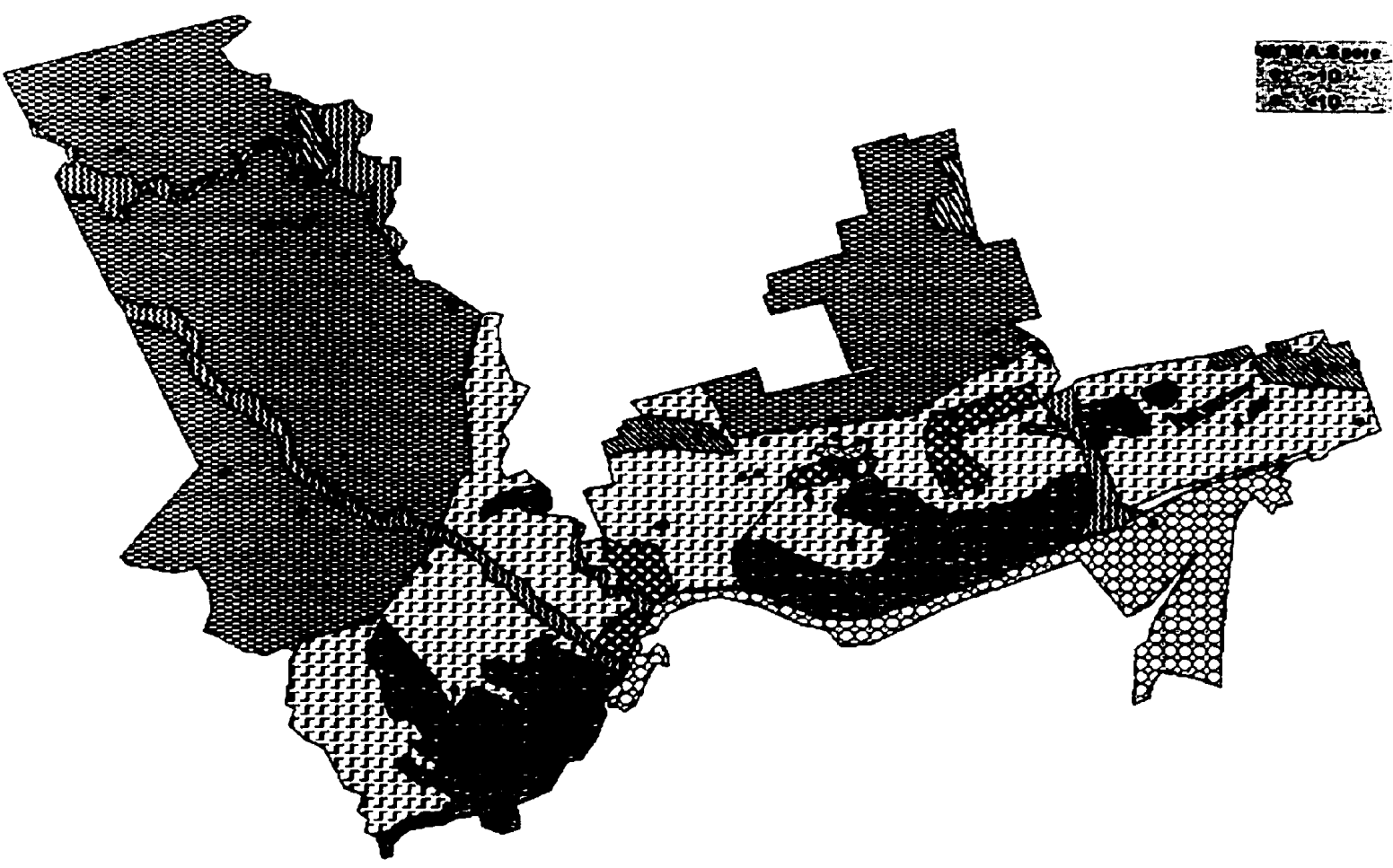




\section{Figure 3.9 - Maximum External Pitting Rates Referenced to Street Map}

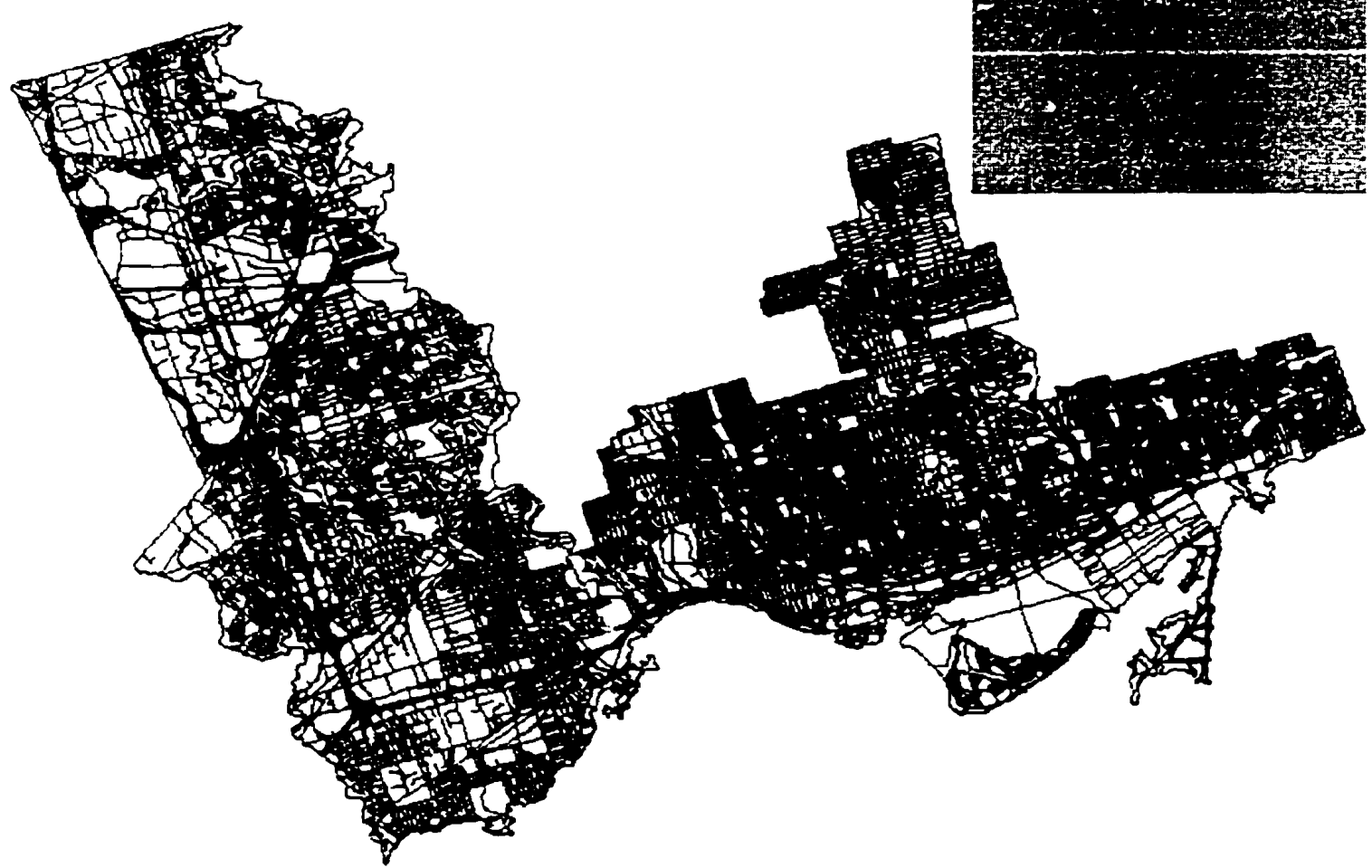

Figure 3.10 - Corrosion Index Referenced to Street Map

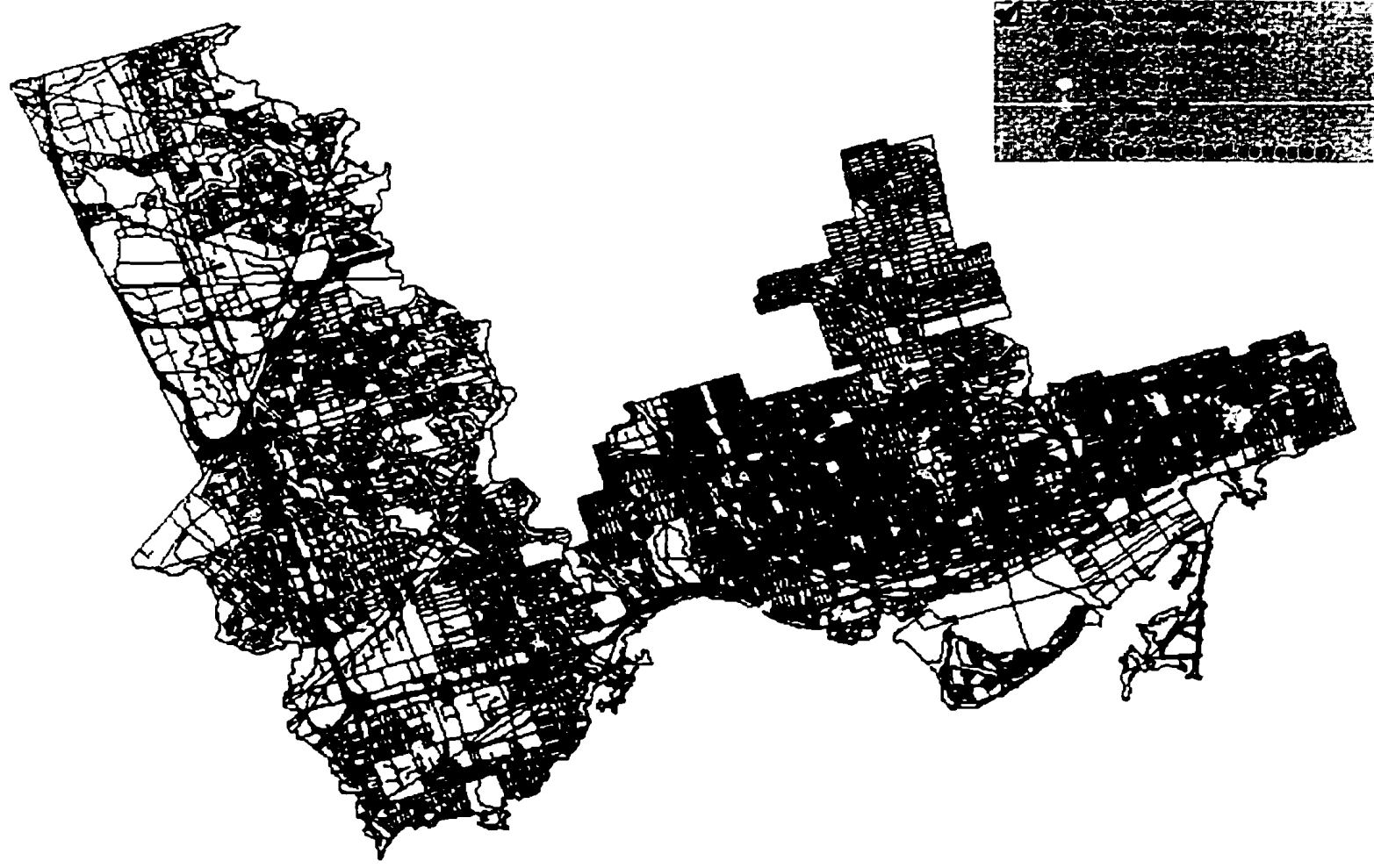




\subsection{Conclusions}

While GIS's are being used by many cities to manage their assets the level of complexity regarding the type of data stored varies widely. A survey of 35 cities, found that very few organizations completely rely on a GIS based system to store, maintain and retrieve records but the trend is heading that way. The survey also found that GIS's have been successfully used by other cities to plan and prioritize water main rehabilitation programs.

When the data collected during the City of Toronto water main investigation was spatially analyzed with a GIS it was found that:

- Based on the AWWA soil corrosiveness scoring system the district of Etobicoke's water mains are located in soils considered to be "corrosive".

- With one exception, all of the soil samples taken from the district of Etobicoke had resistivities lower than $2000 \Omega \cdot \mathrm{cm}$. Since low soil resistivity increases the risk for external corrosion, Etobicoke's water mains are potentially at greater risk than those located in the district of Toronto.

- Water mains located in the district of Etobicoke have experienced higher external pitting rates and show more evidence of external corrosion than do water mains located in the district of Toronto.

- Generally, water mains in the City of Toronto are not at risk for deterioration due to sulphate reducing bacteria. However, there is some evidence indicating that water mains in the northern part of the district of Etobicoke are potentially at increased risk for microbiological corrosion. Additional investigations are needed to confirm this.

\subsection{Acknowledgements}

Funding for this project was provided by the city of Toronto, Ontario. The Authors would also like to thank Robert Klimas of the City of Toronto for his assistance in providing information on the use of GIS by the City. The Author would also like to thank all the individuals who responded to the GIS survey.

\subsection{References}

ANSI/AWWA C105/A25.5-99. American National Standard for Polyethylene Encasement for Ductile-Iron Pipe Systems. American Water Works Association, Denver Colorado.

ASTM D2488-93 (1993). Standard Practice for Description and Identification of Soils (VisualManual Procedure). American Society for Testing and Materials, New York, New York.

ASTM G46-94. Standard Guide for Examination and Evaluation of Pitting Corrosion. American Society for Testing and Materials, New York, New York. 
ASTM G51-95. Standard Test Method for Measuring pH of Soil for Use in Corrosion Testing. American Society for Testing and Materials, New York, New York.

ASTM G57-95a. Standard Test Method for Field Measurement of Soil Resistivity Using the Wenner Four Electrode Method. American Society for Testing and Materials, New York, New York.

Bodner, N. and Lim, E.L. 1999. Water Main Decision Support System Seizes Advantages. City of Seattle, Washington. Personnel Communications.

Bontje, J. 2000. City of London, Ontario. GIS Coordinator. Personal Communications.

Dalton, K. 2000. City of Winnipeg, Manitoba. Supervisor of Drafting and Graphic Services Branch, Engineering Division, Water and Wastewater Department. Personal Communications.

Fishley, R. 2000. City of Saskatoon, Saskatchewan. GIS Design Analyst. Personal Communications.

Hendron, L. 2000. City of Spokane. Senior Engineer, Capital Programs and GIS. Personal Communications.

Hodgson, J. Town of Markham, Ontario. GIS2000 Conference Presentation. The Internet and Data Warehousing - Ideal Technologies for Municipalities. Personal Communications.

Hudson, R. 2000. City of Houston, Texas. Senior Assistant Director, Planning and Operations Support, Public Works and Engineering. Personal Communications.

Iverson, W.P. 1984. Mechanism of Anaerobic Corrosion of Steel by Sulfate Reducing Bacteria. Materials Performance. March, 1984. p. 28-30.

Joyce, B. 2000. Town of Richmond Hill, Ontario. Personal Communications.

Kilmas, R. 2000. City of Toronto, Ontario - Works and Emergency Services. Personal Communications.

Kuhr, C.A.H and Vlught, L.W. 1934. Water, 18, p. 147.

Mallett, A. 2000. City of Victoria, B.C. Engineering Information and Technology Section. Personal Communications.

McDonald, A. 2000. City of Lethbridge, Alberta. Personal Communications.

Musgrave, T. 1996. Ignore GIS - Information Management is the Key. AGI'96 Conference Proceedings. Association for Geographic Information. England.

Pape, M. 2000. City of Kitchener, Ontario. Drafting Room Supervisor - Special Projects, Public Works Departments. Personal Communications. 
Seica et al. 2000. Evaluation and Testing of Cast-iron and Ductile Iron Water Main Samples - Final Report to City of Toronto, Department of Civil Engineering, University of Toronto, Toronto, Ontario, June 2000, ISBN: 0-7727-7551-6.

Shields, B. 2000. City of Adelaide, Australia. Senior GIS Officer. Personal Communications.

Simpson, L. 2000. City of Abilene, Texas. Assistant Director of Water Utilities. Personal Communications.

Stern, C. 2000. LADWP Uses GIS to Help Develop Five-Year Plan. ESRI website. www.esri.com/industriesiwater/writes/five_year.html.

Turalba, S. 2000. City of Seattle, Washington. GISMater Supply and Treatment. Personal Communications.

Ross, P. 2000. City of Guelph, Ontario. Personal Communications. 


\subsection{Appendix - Sample Questionnaire}

1) Does your Public Works Department (specifically the waterworks department) use GIS? If yes, how long has it been in use?

2) What type of GIS applications are being used (ArcView, Arclnfo, Mapinfo, etc..)?

3) Is the internet used in any way to provide access to the GIS database?

4) In creating the GIS, how much of the total time and cost would you estimate was spent on developing/converting/creating the databases? (ie; did paper records have to be digitized, did new data have to be collected or old digital data converted?)

5) How detailed is the information that is available through your GIS system? (ie; in the case of water mains, can historical data about repairs and maintenance be accessed, workorders?)

6) Is the GIS database static or dynamic? By this I mean is it updated frequently (real time, daily, weekly, etc...) or infrequently?

7) Down to what level can the information stored in the GIS database be accessed? Can a work crew in the field access the database or is access limited to managers?

8) What are the future plans (if any) for GIS? If it hasn't been done already, are their any plans to undertake a systematic effort to update the database or to make the data available to a wider range of people (down to the work crew level)?

9) Based on your own experience has using GIS made it easier and more efficient to maintain and monitor the city's infrastructure? What would you do improve the system?

10) As someone in the industry, are there any questions you would like asked about how other Public Works Departments are using GIS? 


\subsection{Summary}

The external corrosion of buried cast-iron water mains is a complex phenomenon influenced by many factors. While the corrosion processes which cause water mains to deteriorate are understood and the soil properties which affect the rate of corrosion have been identified there is great difficulty in applying that knowledge to practical problems. As shown by the results of this investigation no single soil property can be used to accurately predict the rate of external corrosion all of the time. External and localized factors such as stray direct current may cause severe corrosion even in soils with high resistivity, neutral pH's and no sulphate reducing bacteria. However, the data collected during this investigation does indicate that of the various soil properties tested for, resistivity is the best indicator of the external corrosion rate.

The data-set collected during this investigation is too small to allow accurate predictions to be made about which areas of Toronto's water distribution network are most at risk. for deterioration in the future. If it is desired to produce some sort of predictive model it will be necessary to develop a larger database about the properties of Toronto's soils. Such a database would also serve to better define the influence of the various soil properties on the external corrosion rate. Perhaps a larger dataset would show a clearer correlation between the external corrosion rate and resistivity, $\mathrm{pH}$ and sulphide content. It is the opinion of the author that such a database combined with an accurate surface soil map would be a useful predictive tool. Other cities have successfully utilized GIS technology to access such databases. Such a GIS could also be linked with a statistical program to further predict which areas of the system are most likely at risk for deterioration.

This thesis has also highlighted some future areas of research regarding how soil influences external water main corrosion. One area would be to study how the various native soils in the Toronto area affect the polarization rate of cast-iron. Establishing if a certain soil formation depolarizes the cathode or anode would be useful for identifying potential problem areas. Another area of research would be to identify the specific sulphate reducing bacteria present in Toronto's soils and quantify the relationship between a soil's sulphide content and the amount of bacteria present. This would also be useful towards refining the AWWA soil corrosiveness scoring system regarding sulphides (as it presently only describes the sulphide content of a soil qualitatively). A final potential area for study would be to examine how chloride contamination affects the external corrosion rate of cast-iron in various soils 
(including man-made fills). This is of importance because it may be found that granular fills (which based on their "native" properties should be relatively non-corrcsive) become contaminated very quickly by chlorides lowering their resistivity. If used as backfill for trenches, they potentially could provide a worse environment for cast-iron pipes then the native soil they are replacing.

At the very least this study has served to highlight the difficulties in conducting a water main corrosion investigation. Proper sampling techniques and transportation of samples are hard to achieve in the field when the work is being undertaken by a crew whose first priority is to repair a water main break and restore customer service. Future studies should consider a dedicated crew for the project with measurements being made in-situ. Technologies exist which allow in-situ readings of soil resistivity, $\mathrm{pH}$, moisture content and redox potential to be made quickly. Combined with selective sampling of water main sections from various locations across the city a database depicting the state of Toronto's water distribution network could quickly be built.

Toronto's water distribution system has performed admirably over the past century. However, the likelihood of failures increases with each year. At some future time, a point will be reached where rehabilitation is no longer effective and portions of the distribution network will have to be replaced. A better understanding of the factors which cause cast-iron water mains to deteriorate will allow repair and replacement plans to be made in a structured manner. Towards that goal, this thesis provides the basis for understanding how soil influences the external corrosion of Toronto's water mains. 


\section{Appendix A}




\begin{tabular}{|c|c|c|c|c|c|c|c|c|c|c|c|}
\hline \multicolumn{7}{|c|}{ Sample Inlormation } & \multicolumn{5}{|c|}{ Soll Intormatton } \\
\hline $10 \mathrm{No}$. & $\begin{array}{l}\text { Ago } \\
\text { [Years] }\end{array}$ & $\begin{array}{l}\text { Pipe } \\
\text { (Y/N) }\end{array}$ & $\begin{array}{l}\text { Break } \\
\text { (Y/N) }\end{array}$ & $\begin{array}{c}\text { Soli } \\
\text { (Y/N) }\end{array}$ & $\begin{array}{l}\text { Form } \\
(Y / N)\end{array}$ & $\begin{array}{l}\text { Origin } \\
(Y / N)\end{array}$ & $\begin{array}{l}\text { Sulphide Concentration } \\
\text { [mg/kg dry sol]] }\end{array}$ & $\mathrm{pH}$ & $\begin{array}{l}\text { Resistivity } \\
\text { [ohms.cm] }\end{array}$ & Soll ID & $\begin{array}{l}\text { Molsture } \\
\text { Content }\end{array}$ \\
\hline 1 & 124 & $\bar{Y}$ & $\bar{Y}$ & $\bar{Y}$ & $\overline{\mathrm{Y}}$ & Toronto & 105 & 94 & 2892 & $\mathrm{CHMH}$ (maybe $\mathrm{OH}$ ) & 21 \\
\hline 2 & 105 & $\mathbf{Y}$ & $\mathrm{Y}$ & $\mathbf{Y}$ & $Y$ & Toronto & 182 & B 7 & 2882 & SP.SM & 23 \\
\hline 3 & 88 & $\mathbf{Y}$ & $Y$ & Y & $Y$ & Toronto & 0.53 & 88 & 14846 & SP & 23 \\
\hline 4 & 75 & $Y$ & Y & $Y$ & $Y$ & Toronto & 081 & 95 & 948 & CLML & 25 \\
\hline 5 & 80 & $\mathbf{Y}$ & $\mathbf{Y}$ & $\mathbf{N}$ & $Y$ & Toronto & & . & & . & . \\
\hline $\boldsymbol{\theta}$ & 122 & $Y$ & Y & $\mathbf{Y}$ & $Y$ & Toronto & 025 & 8.7 & 545 & $\mathrm{CH} / \mathrm{MH}$ & 14.6 \\
\hline 7 & 122 & $\mathbf{N}$ & $Y$ & $\mathbf{N}$ & $Y$ & Toronto & & . & $\cdot$ & . & - \\
\hline 8 & 26 & $Y$ & $\gamma$ & $\mathbf{N}$ & $\mathbf{Y}$ & Toronto & . & . & . & . & - \\
\hline $\boldsymbol{9}$ & 93 & Y & $\mathbf{N}$ & $Y$ & Y & Toronto & 0.20 & 8.2 & 1973 & SC & 14.6 \\
\hline 10 & 109 & $Y$ & $\mathbf{N}$ & $\mathbf{N}$ & Y & Toronlo & · & $\cdot$ & . & . & - \\
\hline 11 & 108 & $Y$ & $\mathbf{N}$ & $Y$ & $\mathbf{Y}$ & Toronto & 0.18 & 80 & 5252 & SP.SM & 5.4 \\
\hline 12 & 93 & Y & N & $Y$ & $\mathbf{Y}$ & Toronlo & 046 & 91 & 1408 & $\mathrm{CL}$ & 19 \\
\hline 13 & B0 & $\mathbf{Y}$ & N & Y & $Y$ & Toronto & 0.28 & 78 & 13860 & SP.SM & 8.4 \\
\hline 14 & $?$ & $\mathbf{Y}$ & $\mathbf{Y}$ & $\mathbf{Y}$ & $\mathbf{N}$ & Toronto & 0.18 & 90 & 6000 & sc & 12.4 \\
\hline 15 & 121 & $Y$ & Y & $\mathbf{N}$ & $Y$ & Toronto & & 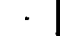 & 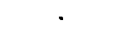 & . & - \\
\hline 16 & 121 & $\mathbf{Y}$ & $\mathbf{Y}$ & $\mathbf{N}$ & $Y$ & Toronto & . & . & . & . & - \\
\hline 17 & 86 & $\mathbf{Y}$ & $\mathbf{N}$ & Y & $Y$ & Toronto & 034 & 8.7 & 13860 & sc & 8.9 \\
\hline 18 & 121 & $\mathbf{Y}$ & Y & Y & $\gamma$ & Toronto & 0.21 & 95 & 1460 & MUSM & 18.3 \\
\hline 19 & 89 & $Y$ & Y & Y & $Y$ & Toronto & 6.60 & 8.7 & 424 & $\mathrm{CH}$ (maybe $\mathrm{OH}$ ) & 30.1 \\
\hline 20 & 117 & $Y$ & $\mathbf{N}$ & Y & Y & Toronto & 0.00 & 0.2 & 2673 & $\mathrm{SC} / \mathrm{Cl}$ & 18.1 \\
\hline 21 & 85 & $\mathbf{Y}$ & $\mathbf{N}$ & Y & $\gamma$ & Toronto & 0.50 & B.8 & 36.2 & SM & 20 \\
\hline 22 & 63 & $\mathbf{Y}$ & $\mathbf{N}$ & $\mathbf{Y}$ & 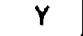 & Toronto & 0.63 & 0.1 & 10888 & SP & 4.3 \\
\hline 23 & 63 & $\mathbf{Y}$ & $\mathbf{N}$ & Y & Y & Toronto & 063 & 94 & 2200 & sc & 3 \\
\hline 24 & 86 & $\mathrm{Y}$ & $\mathbf{N}$ & $\gamma$ & $\mathbf{Y}$ & Toronto & 0.38 & 8.2 & 1683 & SM & 9.5 \\
\hline 25 & 124 & $Y$ & $\mathbf{Y}$ & $\mathbf{N}$ & $Y$ & Toronto & . & . & . & . & - \\
\hline 26 & 122 & $\gamma$ & $\mathbf{Y}$ & Y & $Y$ & Toronto & 4.43 & 0.2 & 342 & $\mathrm{CH}$ & 21.7 \\
\hline 27 & 76 & Y & $\mathbf{N}$ & $\gamma$ & $\mathbf{Y}$ & Toronto & 000 & 77 & 2218 & MUAL & 19.3 \\
\hline 28 & 77 & $Y$ & $\mathbf{Y}$ & $Y$ & Y & Toronto & 005 & 84 & 1895 & sw & 10.7 \\
\hline 28 & 122 & $Y$ & $Y$ & $Y$ & $Y$ & Toronto & 0.76 & 95 & 1997 & sc & 16.2 \\
\hline 30 & $?$ & $Y$ & $Y$ & $Y$ & $\mathbf{N}$ & Toronto & 071 & 9.5 & 6688 & SW.SM & 8.8 \\
\hline 31 & 90 & $\gamma$ & $\mathbf{N}$ & $Y$ & $Y$ & Toronto & 015 & 88 & 1827 & SC & 13.8 \\
\hline 32 & 87 & $Y$ & Y & $Y$ & $Y$ & Toronto & 040 & 92 & 987 & $\mathrm{CH}$ & 154 \\
\hline 33 & 90 & $Y$ & $Y$ & $Y$ & $\mathbf{N}$ & Toronto & 0.59 & 105 & 1378 & sw & 12.5 \\
\hline 34 & $?$ & $Y$ & $Y$ & $Y$ & $\mathbf{N}$ & Toronto & 0.41 & 0.1 & 5145 & sc & 18.4 \\
\hline 35 & 89 & $Y$ & $N$ & $Y$ & $Y$ & Toronto & 0.74 & 85 & 3084 & $\mathbf{S P}$ & 6.4 \\
\hline 36 & $?$ & $Y$ & $\mathbf{N}$ & $Y$ & $\mathbf{N}$ & Toronto & 0.83 & 7.7 & 11521 & SP & 7.8 \\
\hline 37 & $?$ & $Y$ & $\mathbf{N}$ & $Y$ & $\mathbf{N}$ & Toronto & 081 & 80 & 3894 & CLMML & 5.4 \\
\hline 38 & 73 & $Y$ & $\mathbf{N}$ & $Y$ & $Y$ & Toronto & 0.65 & 8.6 & 2410 & SC & 7.8 \\
\hline
\end{tabular}




\begin{tabular}{|c|c|c|c|c|c|c|c|c|c|c|c|}
\hline \multicolumn{7}{|c|}{ Sample Information } & \multicolumn{5}{|c|}{ Soll information } \\
\hline$\overline{10 \text { No. }}$ & $\begin{array}{c}\text { Age } \\
\text { [Years] }\end{array}$ & $\begin{array}{l}\text { Pipe } \\
\text { (Y/N) }\end{array}$ & $\begin{array}{l}\text { Break } \\
(Y / N)\end{array}$ & $\begin{array}{l}\text { Soll } \\
(Y / N)\end{array}$ & $\begin{array}{l}\text { Form } \\
(\mathrm{Y} / \mathrm{N})\end{array}$ & $\begin{array}{l}\text { Origln } \\
(Y / N)\end{array}$ & $\begin{array}{l}\text { Sulphide Concentration } \\
\text { [mg/kg ofy sol] }\end{array}$ & $\overline{\mathrm{pH}}$ & $\begin{array}{l}\text { Resistivity } \\
\text { [ohms.cm] }\end{array}$ & Soll ID & $\begin{array}{l}\text { Molsture } \\
\text { Content }\end{array}$ \\
\hline 39 & 122 & $\bar{Y}$ & $\bar{N}$ & $\bar{N}$ & $\bar{Y}$ & Toronto & $\overline{7}$ & . & - & 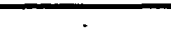 & \\
\hline 40 & 85 & $Y$ & $Y$ & $Y$ & $Y$ & Toronto & 0.38 & 85 & 1787 & $\mathrm{CH}$ (maybe $\mathrm{OH}$ ) & 247 \\
\hline 41 & $?$ & $Y$ & $\mathrm{~N}$ & $\mathbf{Y}$ & $N$ & Toronto & 1.32 & 84 & 22600 & $\mathrm{sp}$ & 1.5 \\
\hline 42 & $?$ & $Y$ & $\mathbf{N}$ & Y & $\mathrm{N}$ & Toronto & 0.00 & 8.2 & 2560 & $S M$ & 181 \\
\hline 43 & 87 & $\mathbf{N}$ & Y & $\mathbf{N}$ & $Y$ & Toronto & . & . & . & . & . \\
\hline 44 & $?$ & $\mathbf{Y}$ & Y & N & $\mathrm{N}$ & Toronto & . & . & . & . & . \\
\hline 45 & 76 & $Y$ & $\mathbf{N}$ & $Y$ & $\mathbf{Y}$ & Toronto & 1.22 & 8.9 & 2872 & sc & 0.6 \\
\hline 48 & 34 & $Y$ & Y & $Y$ & $\mathbf{N}$ & Toronto & 1.13 & 0.2 & 453 & SP.SC & 8.7 \\
\hline 47 & $?$ & $Y$ & $\mathbf{N}$ & $Y$ & $\mathbf{N}$ & Toronto & 0.23 & 7.0 & 4352 & SP.SM & 6.5 \\
\hline $48^{\circ}$ & 21 & $Y$ & $Y$ & $\mathbf{Y}$ & $Y$ & Toronto & 0.65 & $8 \theta$ & 10894 & sc & 68 \\
\hline 49 & $?$ & $Y$ & $\gamma$ & $Y$ & $\mathbf{N}$ & Toronto & 0.70 & 8.7 & 909 & $\mathrm{CH}$ & 13.4 \\
\hline 50 & 114 & Y & $\mathbf{N}$ & Y & Y & Toronto & 0.49 & B. & 2088 & $\mathrm{CH}$ & 12.6 \\
\hline 51 & 82 & $Y$ & $Y$ & $Y$ & $Y$ & Toronto & 1.72 & 0.1 & 200 & $\mathrm{CH}$ & 24.2 \\
\hline 52 & 33 & Y & $\mathbf{N}$ & $\mathbf{N}$ & $\mathbf{N}$ & Toronto & . & . & . & . & . \\
\hline 53 & $?$ & Y & $Y$ & N & N & Toronto & . & . & . & . & . \\
\hline 54. & O4 & $Y$ & $\mathbf{N}$ & $Y$ & $\mathrm{~N}$ & Toronto & 0.58 & BO & B057 & SM & 11.9 \\
\hline 55 & $?$ & $Y$ & $Y$ & $\mathbf{N}$ & $\mathbf{N}$ & Toronto & . & . & & $\cdot$ & . \\
\hline 56 & 50 & $Y$ & $\mathbf{N}$ & $Y$ & $\mathbf{N}$ & Toronto & 1.02 & 82 & 3124 & MHISM & 17.6 \\
\hline 57 & 88 & $Y$ & $N$ & $Y$ & $Y$ & Toronto & 1.56 & 8.4 & 16433 & SP & 6 \\
\hline 58 & 79 & $Y$ & $N$ & $Y$ & $Y$ & Toronto & 1.09 & 85 & B595 & SP & 2.6 \\
\hline 59 & 85 & $Y$ & $\mathbf{N}$ & $Y$ & $Y$ & Toronto & 090 & 9.0 & 5947 & SP & 43 \\
\hline 60 & 92 & $Y$ & $\mathbf{N}$ & $Y$ & Y & Toronto & 1.26 & 85 & 5792 & SP & 35 \\
\hline 61 & 80 & Y & $N$ & $Y$ & Y & Toronto & 1.55 & 89 & 10778 & GP & 53 \\
\hline 62 & $?$ & $Y$ & $Y$ & $Y$ & $\mathbf{N}$ & Elobicoke & 1.83 & 8.9 & 980 & $\mathrm{CH}$ & 17 \\
\hline 63 & $?$ & $Y$ & $\gamma$ & $Y$ & $\mathbf{N}$ & Elobicoke & 0.97 & 8.6 & 10481 & sw & 19.7 \\
\hline 64 & $?$ & N & $\gamma$ & $Y$ & $\mathbf{N}$ & Etobicoke & 0.44 & 83 & 1354 & CLML & 26.2 \\
\hline 65 & $?$ & $\mathbf{N}$ & $Y$ & $Y$ & $\mathbf{N}$ & Etobicoke & 000 & 88 & 1730 & $\mathrm{CH}$ & 25.4 \\
\hline 66 & $?$ & $\mathbf{N}$ & $Y$ & Y & $\mathbf{N}$ & Elobicoke & 13.81 & 86 & 1725 & $\mathrm{CH}$ & 24.4 \\
\hline 67 & $?$ & $Y$ & $\mathbf{Y}$ & $Y$ & $\mathbf{N}$ & Elobicoke & 088 & 82 & 867 & $\mathrm{CH}$ & 27.3 \\
\hline 68 & $?$ & $Y$ & $Y$ & $\gamma$ & $\mathbf{N}$ & Etobicoke & 2.50 & 80 & 1801 & CLML & 18 \\
\hline 69 & 44 & $Y$ & $Y$ & $Y$ & $Y$ & Etobicoke & 0.75 & 85 & 1608 & GP & 238 \\
\hline 70 & $?$ & $\gamma$ & $Y$ & $Y$ & $\mathbf{N}$ & Elobicoke & 2.51 & 85 & 1506 & MHUSM & 20.5 \\
\hline 71 & 40 & $Y$ & $Y$ & $Y$ & $Y$ & Scarborough & 1.38 & 83 & $\mathrm{n} / \mathrm{a}$ & $\mathrm{CL}$ & 13.8 \\
\hline 72 & $?$ & $Y$ & $Y$ & $Y$ & $Y$ & Scarborough & 26.10 & 82 & 3627 & CLGC & 15.8 \\
\hline 73 & $?$ & $Y$ & $Y$ & $Y$ & $Y$ & North York & 1.44 & B 3 & 1500 & $\mathrm{CH}$ & 18.6 \\
\hline 74 & 46 & $Y$ & $Y$ & $\mathbf{N}$ & $Y$ & Elobicoke & . & . & - & . & . \\
\hline 75 & $?$ & $Y$ & Y & $Y$ & $\gamma$ & North York & 2.11 & 91 & 869 & $\mathrm{CH}$ & 21.5 \\
\hline 70 & 43 & $Y$ & $Y$ & $Y$ & $Y$ & Elobicoke & 2.33 & 80 & 228 & $\mathrm{CH}$ & 167 \\
\hline 77 & 46 & $Y$ & $Y$ & $Y$ & $Y$ & Elobicoke & 631 & 85 & 4542 & CUGC & 11.8 \\
\hline
\end{tabular}




\begin{tabular}{|c|c|c|c|c|c|c|c|c|c|c|c|}
\hline \multicolumn{7}{|c|}{ Sample Information } & \multicolumn{5}{|c|}{ Soll Information } \\
\hline ID No. & $\begin{array}{c}\text { Age } \\
\text { [Years] }\end{array}$ & $\begin{array}{l}\text { Pipe } \\
\text { (Y/N) }\end{array}$ & $\begin{array}{l}\text { Break } \\
(Y / N)\end{array}$ & $\begin{array}{l}\text { Soll } \\
\text { (Y/N) }\end{array}$ & $\begin{array}{l}\text { Form } \\
(Y / N)\end{array}$ & $\begin{array}{l}\text { Origin } \\
(Y / N)\end{array}$ & $\begin{array}{l}\text { Sulphlde Concentration } \\
\text { [mg/kg dry soli] }\end{array}$ & $\overline{p H}$ & $\begin{array}{l}\text { Resistlvity } \\
\text { [ohms.cm] }\end{array}$ & Soll110 & $\begin{array}{l}\text { Moisture } \\
\text { Content }\end{array}$ \\
\hline 78 & $?$ & $Y$ & Y & $Y$ & Y & Toronto & 111 & 87 & 2145 & CHUGC & 167 \\
\hline 79 & 75 & $Y$ & $Y$ & $Y$ & $Y$ & Elobicoke & 592 & 90 & 1178 & $\mathrm{Cl}$ & 19.8 \\
\hline 80 & 50 & $Y$ & Y & $\mathbf{Y}$ & Y & Etobicoke & 0.00 & 82 & 1162 & CL. (maybe OL) & 24.9 \\
\hline 81 & 75 & $\mathbf{Y}$ & Y & $\mathbf{Y}$ & $\mathbf{Y}$ & Etobicoke & 000 & 8.4 & 6885 & SP.SM & 17.6 \\
\hline 82 & $?$ & $Y$ & $\mathbf{Y}$ & Y & Y & Elobicoke & 5.10 & B. 8 & 501 & $\mathrm{CH}$ & 17.7 \\
\hline 83 & 48 & $Y$ & Y & Y & Y & Etobicoke & 1.44 & 8.3 & - & CLML & 10.6 \\
\hline B4 & 52 & $Y$ & Y & $\mathbf{Y}$ & Y & Etobicoke & 0.00 & 9.0 & 409 & $\mathrm{CH}$ & 31.6 \\
\hline 85 & 42 & $Y$ & $\mathbf{Y}$ & $\mathbf{Y}$ & Y & Etobicoke & 1.72 & 9.0 & . & CL & 16.8 \\
\hline 88 & 52 & $Y$ & $\mathbf{Y}$ & Y & Y & Etobicoke & 1.05 & 0.1 & 573 & $\mathrm{CH}$ (maybe $\mathrm{OH}$ ) & 34.8 \\
\hline 87 & $?$ & $Y$ & $\mathbf{Y}$ & Y & $Y$ & North York & 1.14 & 8.5 & 1906 & sc & 18.8 \\
\hline 88 & 45 & $\mathbf{Y}$ & Y & $Y$ & $\mathbf{Y}$ & Etobicoke & 167.88 & 9.0 & 1447 & $\mathrm{CH}$ (maybe $\mathrm{OH}$ ) & 13.9 \\
\hline 89 & $?$ & $Y$ & $Y$ & $\mathbf{Y}$ & $\mathbf{r}$ & North York & 1.47 & 0.7 & 3614 & CLISC & 12.7 \\
\hline 90 & $?$ & Y & $Y$ & $\mathbf{Y}$ & Y & North York & 4.05 & B.3 & 433 & sc & 16.9 \\
\hline 91 & 43 & $\mathbf{Y}$ & $\mathbf{Y}$ & Y & $\mathbf{Y}$ & Elobicoke & 221 & 8.8 & 498 & $\mathrm{CH}$ & 27.7 \\
\hline 92 & 48 & $Y$ & Y & $Y$ & Y & Etobicoke & 2.87 & 8.9 & 578 & $\mathrm{CL}$ (maytoo $\mathrm{OL}$ ) & 14.2 \\
\hline 93 & 36 & $Y$ & $\mathbf{Y}$ & $Y$ & Y & Elobicoke & 2.00 & 8.8 & 1706 & $\mathrm{CH}$ & 156 \\
\hline 94 & $?$ & $r$ & $\mathbf{Y}$ & Y & $\mathbf{Y}$ & North York & 1.95 & 8.1 & 1429 & $\mathrm{CH}$ & 24.8 \\
\hline 95 & 25 & $\gamma$ & Y & $\mathbf{Y}$ & Y & Elobicoke & 17.70 & 92 & 817 & sc & 245 \\
\hline 96 & 69 & $Y$ & $Y$ & Y & $Y$ & Elobicoke & 0.26 & 8.6 & 391 & $\mathrm{CL}$ & 20.6 \\
\hline 97 & 41 & $Y$ & Y & Y & $Y$ & Elobicoke & 0.99 & 9.3 & 727 & GC & 14.5 \\
\hline 98 & 70 & $Y$ & Y & $Y$ & Y & Elobicoke & 28.76 & 7.2 & 500 & $\mathrm{CH}$ & 32 \\
\hline 99 & 41 & $Y$ & $Y$ & $Y$ & Y & Elobicoke & 6.52 & 8 & 1684 & $\mathrm{CH}$ & 7.4 \\
\hline 100 & 46 & $Y$ & $Y$ & $Y$ & $\mathbf{Y}$ & Etobicoke & 0.22 & 7.6 & 1270 & $\mathrm{CL}$. & $3:$ \\
\hline 109 & 45 & Y & $Y$ & Y & $Y$ & Etobicoke & 1.37 & 8.2 & 1702 & $\mathrm{CH}$ & 32.1 \\
\hline 102 & 49 & $Y$ & $Y$ & Y & Y & Etobicoke & 038 & 7.8 & 2054 & SM & 10 \\
\hline 103 & 42 & $\mathbf{N}$ & Y & $\mathbf{Y}$ & Y & Etobicoke & 3.05 & 7.8 & 3249 & sc & 17.1 \\
\hline 104 & 46 & $\mathbf{Y}$ & Y & $Y$ & $Y$ & Etobicoke & 1.71 & 8.7 & 698 & $\mathrm{CH}$ & 159 \\
\hline 105 & 75 & $\mathbf{Y}$ & $Y$ & Y & $Y$ & Elobicoke & 1.43 & 8.2 & 1795 & CL & 17.7 \\
\hline 106 & 45 & Y & $Y$ & Y & $Y$ & Elobicoke & 3.93 & 8.6 & 712 & $\mathrm{CH}$ & 226 \\
\hline 107 & 43 & Y & Y & Y & $Y$ & Elobicoke & 084 & 8.3 & 1048 & ML/SM & 21.5 \\
\hline 108 & 30 & $Y$ & Y & Y & Y & Elobicoke & 0.30 & 8.5 & 1293 & $\mathrm{CH}$ & 368 \\
\hline 109 & $?$ & $\gamma$ & $Y$ & $Y$ & $\mathbf{N}$ & Elobicoke & 083 & 7.9 & 1110 & $\mathrm{CL}$ & 19.8 \\
\hline Al & $?$ & $\mathbf{Y}$ & Y & Y & $\mathbf{N}$ & University of Toronto & 115 & 0.4 & 2357 & SW.SC & 202 \\
\hline A2 & $?$ & Y & $\mathbf{N}$ & Y & $\mathbf{N}$ & University of Toronto & 0.97 & 8.3 & 11979 & SP & 11.8 \\
\hline A3 & $?$ & $\mathbf{Y}$ & $\mathbf{N}$ & $\mathbf{Y}$ & $\mathbf{N}$ & University of Toronto & 134 & 84 & 3702 & $\mathrm{M} \cup \mathrm{CL}$ & 19.3 \\
\hline A4 & $?$ & $\mathbf{N}$ & $\mathbf{N}$ & $\mathbf{N}$ & N & University of Toronto & - & - & - & - & - \\
\hline A5 & $?$ & $\mathbf{Y}$ & $\mathbf{N}$ & $\mathbf{N}$ & $\mathbf{N}$ & University of Toronto & . & . & . & . & - \\
\hline$A B$ & $?$ & $\mathbf{N}$ & $\mathbf{N}$ & $\mathbf{N}$ & $\mathbf{N}$ & University of Toronto & . & - & . & - & - \\
\hline A7 & ? & $\mathbf{N}$ & $\mathbf{N}$ & $\mathbf{N}$ & $\mathrm{N}$ & University of Toronto & . & . & 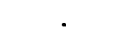 & . & . \\
\hline AB & $?$ & Y & $\mathbf{N}$ & $\mathbf{N}$ & $\mathbf{N}$ & University of Toronto & 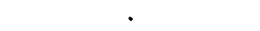 & 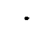 & & & . \\
\hline
\end{tabular}




\begin{tabular}{|c|c|c|c|c|c|c|c|c|c|c|c|c|c|}
\hline & & & & Pitc & Depth & Measu & ureme & ints & & & & & \\
\hline & & & Dutslde & & & & & Inside & & & Pipe Wall & & \\
\hline $\begin{array}{l}10 \\
\text { No. } \\
\text { No }\end{array}$ & $\begin{array}{l}\text { Pit 1 } \\
\text { [mm }\end{array}$ & $\begin{array}{l}\text { Pit 2 } \\
\text { Imm }\end{array}$ & $\begin{array}{l}\text { Pit 3 } \\
\text { [mm }\end{array}$ & $\begin{array}{l}\text { Pit4 } \\
{[\mathrm{mm}}\end{array}$ & $\begin{array}{l}\text { PII } 5 \\
(\mathrm{~mm})\end{array}$ & $\begin{array}{l}\text { PII 1 } \\
\text { (mm }\end{array}$ & $\begin{array}{l}\text { Pit } 2 \\
\text { imm }\end{array}$ & $\begin{array}{l}\text { Pit } 3 \\
\text { imm }\end{array}$ & 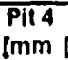 & $\begin{array}{l}\text { Pit5 } \\
\text { Imm }\end{array}$ & $\begin{array}{c}\text { Thickness } \\
{[\mathrm{mm}]}\end{array}$ & $\begin{array}{l}\text { Briel Description of the } \\
\text { Aspect of the Exterior Surface of the Pipe }\end{array}$ & $\begin{array}{l}\text { Briet Descriptlon of the } \\
\text { Aspect of the Interior Surface of the Pipe }\end{array}$ \\
\hline 1 & $\overline{0}$ & $\overline{0}$ & 0 & $\overline{0}$ & 0 & 56 & 34 & 35 & 36 & 52 & 107 & Clean & Many. lew deep. pits distributed uniformly \\
\hline 2 & 36 & 27 & 24 & 22 & 16 & 39 & 38 & 39 & 25 & 25 & 117 & $120^{\prime}$ Medium size shallow pits & $320^{\circ}$ Very many medium shallow pits \\
\hline 3 & 5 & 62 & 52 & 35 & 33 & 27 & 25 & 27 & 6.6 & 23 & 111 & $50 \%$ Unitorm colroston & Many pils distributed uniformly \\
\hline 4 & 0 & 0 & 0 & 0 & 0 & 29 & 28 & 25 & 24 & 26 & 144 & Clean & $270^{\circ}$ Small puts \\
\hline 5 & 27 & 34 & 34 & 4 & 25 & 25 & 45 & 3 & 33 & 26 & 115 & $90^{\circ}$ General corrosion & Few small pits oustributed uniformly \\
\hline 6 & 107 & 107 & 107 & 107 & 66 & 31 & 23 & 38 & 32 & 24 & 107 & $30^{\circ}$ Heavy localised corrosion min holes & Small to medium pits distributed unitormly \\
\hline 8 & 74 & 44 & 63 & 44 & 53 & 0 & 0 & 0 & 0 & 0 & 11 & Chain handing and dragging pallern & Clean \\
\hline 9 & $\mathbf{0}$ & 0 & 0 & 0 & 0 & 2 & 25 & 17 & 16 & 15 & 98 & Clean & Very lew pins \\
\hline 10 & 0 & 0 & 0 & 0 & 0 & 21 & 19 & 18 & 25 & 22 & 126 & Clean & Very lew small pits \\
\hline 11 & 2.7 & 22 & 3 & 19 & 22 & 38 & 28 & 3 & 2 & 24 & 121 & Localised corrosion pits & Few minor localised pits \\
\hline 12 & 27 & 23 & 16 & 14 & 1 & 2 & 22 & 16 & 15 & 22 & 106 & Six localsed and united small pits & $50 \%$ Medium size pits \\
\hline 13 & 48 & 25 & 47 & 25 & 13 & 34 & 64 & 91 & 72 & 52 & 12 & One localised corrosion p & hallow. medium pits distributed uniformly \\
\hline 14 & 0 & 0 & 0 & 0 & 0 & 28 & 17 & 19 & 16 & 21 & 139 & Clean & $120^{\circ}$ Small and one med \\
\hline 15 & 47 & 37 & 3 & 32 & 4 & 33 & 38 & 33 & 28 & 2 & 12 & Two opposite, localised & Few minor pits scallered around \\
\hline 16 & 13 & 64 & 85 & 77 & 53 & 39 & 38 & 39 & 2 & 18 & 13 & $45^{\circ}$ Highly localised corrosi & $50 \%$ medium size pits \\
\hline 17 & 39 & 42 & 27 & 36 & 42 & 29 & 18 & 22 & 11 & 17 & 99 & Localtsed corrosion patch & Very lew localis \\
\hline 18 & 29 & 29 & 21 & 21 & 18 & 31 & 43 & 39 & 32 & 29 & 118 & Less than ten pils in two areas & Ten pits on a longludinal strip \\
\hline 19 & 14 & 15 & 15 & 14 & 1 & 41 & 42 & 32 & 34 & 36 & 117 & Farfly clean & $90^{\circ}$ Few medium size pits \\
\hline 20 & 0 & 0 & 0 & 0 & 0 & 28 & 34 & 28 & 45 & 33 & 127 & Clean & Many medium pits distributed uniformly \\
\hline 21 & 11 & 3 & 88 & 49 & 66 & 54 & 32 & 39 & 3 & 37 & 11 & Extensive general corrosion & Extensive general corrosion \\
\hline 22 & 0 & 0 & 0 & 0 & 0 & 47 & 31 & 24 & 28 & 28 & 109 & Clean & $40 \% \mathrm{~S}$ \\
\hline 23 & 0 & 0 & 0 & 0 & 0 & 41 & 32 & 31 & 34 & 28 & 114 & Clean & Many wde pits distributed uniformly \\
\hline 24 & 32 & 25 & 18 & 19 & 13 & 25 & 27 & 22 & 31 & 33 & 11 & corrosion mide pits & Unitorm corrosion. wide pits, but worse \\
\hline 25 & 0 & 0 & 0 & 0 & 0 & 3 & 25 & 41 & 25 & 24 & 159 & Clean & Few pits \\
\hline 26 & 156 & 156 & 96 & 74 & 66 & 28 & 39 & 34 & 27 & 32 & 156 & general corrosion on $270^{\circ}$, big pits & Many small pits distributed unilosmly \\
\hline 27 & 0 & 0 & 0 & 0 & 0 & 46 & 28 & 25 & 43 & 37 & 128 & Clean & $50 \%$ Small but inany pits \\
\hline 28 & 147 & 88 & 105 & 79 & 6 & 36 & 39 & 36 & 32 & 38 & 177 & deep pits & Few medium pits distributed unitorinly \\
\hline 29 & 24 & 2 & 2 & 15 & 15 & 28 & 24 & 21 & 29 & 21 & 121 & Little localised corrosion & Pits distributed uniformly \\
\hline 30 & 122 & 6 & 6 & 46 & 57 & 25 & 41 & 41 & 23 & 28 & 12 & Heavy uniform corrosion everywhere & Many medium pits distrit \\
\hline 31 & 22 & 22 & 14 & 17 & 19 & 38 & 25 & 19 & 27 & 37 & 156 & Few medium size shallow pils & Few medium pits distibuted everywhere \\
\hline 32 & 114 & 62 & 57 & 44 & 84 & 38 & 35 & 33 & 33 & 39 & 114 & Big pils a & Medrum size pits distributed unitormly \\
\hline 33 & 99 & 99 & 99 & 61 & 45 & 29 & 22 & 16 & 2 & 13 & 9 & Heavly corroded. unde and shallow pits & Very tew localised small pils \\
\hline 34 & 44 & 37 & 23 & 15 & 18 & 51 & 41 & 46 & 49 & 5 & 102 & Localis & Localtsed pits \\
\hline 35 & 17 & 11 & 11 & 13 & 14 & 39 & 27 & 32 & 32 & 38 & 121 & $180^{\circ}$ Few large, shallow pits & Medium size pits distributed uniformly \\
\hline 36 & 0 & 0 & 0 & 0 & 0 & 38 & 24 & 37 & 32 & 43 & 12 & & 270 \\
\hline 37 & 24 & 39 & 22 & 29 & 16 & 44 & 43 & 19 & 22 & 31 & M & Very localised corrosion patch & $50 \%$ Many small pus. the rest un-corroded \\
\hline 38 & 0 & 0 & 0 & 0 & 0 & 25 & 27 & 24 & 24 & 32 & 14 & Clean & 270. Large number of small pils \\
\hline 39 & 0 & 0 & 0 & 0 & 0 & 32 & 32 & 49 & 22 & 28 & 11 & Clean & $50 \%$ Few medum slue pits \\
\hline 40 & 116 & 41 & 44 & 67 & 34 & 3 & 28 & 3 & 25 & 33 & 116 & dly corroded, mass & $45^{\circ}$ Localised general corrosion \\
\hline 41 & 53 & 53 & 43 & 3 & 42 & 43 & 37 & 39 & 42 & 41 & 126 & Big, localised corrosion patch & Pits distributed unitormly \\
\hline 42 & 44 & 35 & 31 & 37 & 33 & 23 & 17 & 22 & 13 & 2 & 119 & Intorm corrosion $270^{\circ}$ large shallow & Two close patches of medium size pits \\
\hline 44 & 12 & 12 & 12 & 12 & 12 & 48 & 27 & 25 & 36 & 31 & 12 & Badly corroded on $50 \%, 7$ penetration holes & Few deep pits \\
\hline 45 & 22 & 19 & 1 & 06 & 06 & 71 & 48 & 25 & 31 & 21 & 131 & Fauly clean & $120^{\circ}$ Medium size pits \\
\hline 46 & 6 & 5 & 26 & 25 & 46 & 43 & 31 & 27 & 19 & 2 & 148 & Few medium size pits distıbuted uniformly & Few medium size pits distributed uniformly \\
\hline 47 & 0 & 0 & 0 & 0 & 0 & 43 & 49 & 48 & 44 & 34 & 13 & Cle & General corrosion and $120^{\circ}$ medium pits \\
\hline & 55 & 57 & 52 & 5 & 54 & 0 & 0 & 0 & 0 & & 114 & sed corro & 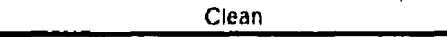 \\
\hline
\end{tabular}




\begin{tabular}{|c|c|c|c|c|c|c|c|c|c|c|c|c|c|}
\hline \multicolumn{11}{|c|}{ Plt Depth Measurements } & \multirow{3}{*}{$\begin{array}{l}\text { Plpe Wall } \\
\text { thlekness }\end{array}$} & \multirow[b]{3}{*}{$\begin{array}{l}\text { Brief Description of the } \\
\text { of the Exterior Surface of the Pipe }\end{array}$} & \multirow[b]{3}{*}{$\begin{array}{l}\text { Brief Description of the } \\
\text { Aspect of the Interior Surface of the Plpe }\end{array}$} \\
\hline 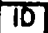 & \multicolumn{5}{|c|}{ Outside } & & \multicolumn{4}{|c|}{ Inside } & & & \\
\hline No. & $\begin{array}{l}\text { Pit 1 } \\
\text { imm }\end{array}$ & $\begin{array}{l}\text { Pit 2 } \\
\text { (mm }\end{array}$ & Pit 3 & $\begin{array}{l}\text { Pit } 4 \\
\text { imm }\end{array}$ & $\begin{array}{l}\text { Pit } 5 \\
\text { imm }\end{array}$ & $\begin{array}{l}\text { PIt } 1 \\
\mathrm{~mm}\end{array}$ & $\begin{array}{l}\text { Pit } 2 \\
\text { Imm }\end{array}$ & Plt 3 & $\begin{array}{l}\text { Pit 4 } \\
\text { imm }\end{array}$ & $\begin{array}{l}\text { Pit } 5 \\
\text { Imm }\end{array}$ & & & \\
\hline 49 & 32 & 3 & 32 & 18 & 18 & 3 & 31 & 3 & 3 & 21 & 15 & Few pils & Few pits \\
\hline 50 & 25 & 22 & 21 & 13 & 11 & 51 & 62 & 45 & 55 & 46 & 116 & 45. Localised small to medium size pils & $270^{\prime}$ Medium size pits \\
\hline 51 & 131 & 59 & 55 & 41 & 44 & 34 & 34 & $3 \mathrm{~A}$ & 32 & 28 & 131 & Heavy localised corrosion & $50 \%$ Medium size pits \\
\hline 52 & 0 & 0 & 0 & 0 & 0 & 0 & 0 & 0 & 0 & 0 & 94 & Clean & Clean \\
\hline 53 & 17 & 17 & 104 & 66 & 46 & 34 & 34 & 38 & 31 & 29 & 17 & Heavily corroded, large and deep pits & Small to medium size pits all around \\
\hline-1 & 46 & 31 & 31 & 15 & 18 & 0 & 0 & 0 & 0 & 0 & 99 & Ten medium size pits & Clean \\
\hline 55 & 2 & 22 & 23 & 18 & 29 & 27 & 19 & 2 & 22 & 22 & 106 & Small pits distributed unilormly & Small pits distributed uniformly \\
\hline 56 & 29 & 32 & 1 & 11 & 34 & 22 & 28 & 32 & 27 & 28 & 116 & Shallow medium pits over $270^{\circ}$ & Few small plis over $270^{\circ}$ \\
\hline 57 & 0 & 0 & 0 & 0 & 0 & 25 & 33 & 34 & 3 & 31 & 179 & Clean & Small to medium pits in three $60^{\circ}$ areas \\
\hline 58 & 0 & 0 & 0 & 0 & 0 & 34 & 32 & 19 & 27 & 25 & 17 & Clean & $120^{\circ}$ Few medium size, shallow pits \\
\hline 59 & 25 & 16 & 14 & 15 & 18 & 34 & 15 & 22 & 11 & 32 & 111 & Many shallow, medium pits all around & General corrosion and $90^{\circ}$ worse strip \\
\hline 60 & 0 & 0 & 0 & 0 & 0 & 32 & 22 & 32 & 38 & 27 & 112 & Clean & Unitorm corrosion, few shallow pits \\
\hline 61 & 0 & 0 & 0 & 0 & 0 & 29 & 18 & 29 & 14 & 21 & 151 & Clean & Few localised pits on a narrow strip \\
\hline 62 & 39 & 36 & 43 & 39 & 2 & 39 & 38 & 41 & 36 & 31 & 108 & Very many small pits distributed uniformly & Pits distributed uniformly \\
\hline 63 & 19 & 0 & 0 & 0 & 0 & 27 & 24 & 24 & 21 & 25 & 102 & One ptl only & Very many pils distibuted uniformily \\
\hline 67 & 6 & 6 & 58 & 44 & 44 & 24 & 27 & 19 & 27 & 3 & 102 & Highly localised corrosion with big pits & $220^{\circ}$ Very many small to medium pits \\
\hline 68 & 16 & 23 & 16 & 16 & 11 & 32 & 29 & 44 & 33 & 38 & 121 & 150. Light uniform corrosion & Localised corrosion strip with medium pits \\
\hline 69 & is & 16 & 17 & 23 & 18 & $5 i$ & 34 & 38 & 3 & 34 & 116 & Light uniform corrosion all around & Localised mde longitudinal corrosion strip \\
\hline 10 & 11 & 11 & 12 & 1 & 17 & 37 & 5 & 34 & 38 & 39 & 105 & Light uniform corrosion all around & Localised longitudinal corrosion strip \\
\hline 71 & 0 & 0 & 0 & 0 & 0 & 35 & 36 & 35 & 39 & 28 & 115 & Clean & Localised corrosion patch with some pits \\
\hline 72 & 112 & 93 & 52 & 54 & 47 & 27 & 27 & 44 & 54 & 23 & 112 & Over $180^{\circ}$ severe corrosion & 30. Uniform corrosion \\
\hline 73 & 0 & 0 & 0 & 0 & 0 & 36 & 36 & 34 & 36 & 22 & 119 & Clean & Pits distributed unitormly \\
\hline 75 & 109 & 109 & 109 & 67 & 51 & 39 & 53 & 47 & 38 & 33 & 109 & 150. Uniform corrosion with holes & Medium size pits distributed unilormiy \\
\hline 76 & 99 & 99 & 99 & 99 & 76 & 42 & 38 & 29 & 31 & 32 & 99 & $50 \%$ Badly corroded wth holes, rest is good & Pits distributen uniformly \\
\hline 78 & 5 & 49 & 42 & 42 & 31 & 41 & 27 & 3 & 39 & 25 & 153 & Few localised, medium, deep pits & Small to medium pits distributed uniformly \\
\hline 79 & 22 & 15 & 21 & 1.1 & 15 & 152 & 39 & 33 & 47 & 4 & 169 & Few pits & Very many small pits distributed unitormly \\
\hline 80 & 8 & 71 & 64 & 28 & 36 & 39 & 33 & 24 & 36 & 33 & 115 & Uniform generalised corrosion & Wide pits distributed unitormly \\
\hline 81 & 34 & 28 & 3 & 27 & 32 & 59 & 5 & 46 & 53 & 63 & 109 & Little localised corrosion & Natrow pits distributed uniformly \\
\hline 83 & 44 & 42 & 38 & 38 & 42 & 38 & 28 & 28 & 22 & 23 & 18 & Localised corrosion strip with many pits & Many small to medium pits over $120^{\circ}$ \\
\hline 84 & 122 & 91 & 81 & 64 & 33 & 3 & 25 & 18 & 14 & 13 & 122 & Localised pits w/ hole, uniform on opposite & Few pits \\
\hline & 42 & 0 & 0 & 0 & 0 & 38 & 33 & 32 & 19 & 2 & 11 & One pil only & Pits distributed unformly \\
\hline 86 & 59 & 92 & 62 & 34 & 69 & 0 & 0 & 0 & 0 & 0 & 143 & $50 \%$ Large and wde pils & Clean \\
\hline 8 & 0 & 0 & 0 & 0 & 0 & 24 & 33 & 36 & 37 & 3 & 128 & Clean & $45^{\circ}$ Area of small plts \\
\hline 8 & 64 & 6 & 46 & 39 & 3 & 43 & 43 & 35 & 36 & 28 & 108 & Two areas of localised corrosion. $120^{\circ}$ apant & Pits distributed uniformly \\
\hline & 27 & 23 & 2 & 18 & 17 & 29 & 41 & 27 & 27 & 23 & 143 & A tew small pits. in good overall condition & In good condition \\
\hline 9 & 66 & 43 & 24 & 22 & 23 & 18 & 22 & 07 & 15 & 1 & 95 & Very few localised pils & Almosi clean \\
\hline 9 & 76 & 76 & 76 & 76 & 52 & 0 & 0 & 0 & 0 & 0 & 76 & Hales, pits distributed unitormly & Clean \\
\hline 93 & 10.2 & 102 & 102 & 8 & 69 & 28 & 3 & 24 & 23 & 25 & 102 & Deep longinudinal groove deep pits & Many small pits distributed unitormly \\
\hline 9 & 73 & 27 & 36 & 21 & 23 & 33 & 32 & 34 & 32 & 31 & 127 & Local pipe mechanical damage & Pits distributed unitormly \\
\hline & 33 & 28 & 14 & 15 & 14 & 38 & 33 & 25 & 19 & 24 & 103 & Very few pits & Very few pits \\
\hline 9 & 128 & 69 & 47 & 38 & 8 & 53 & 53 & 48 & 5 & 44 & 128 & Localised corrosion with large hole & Pits distribuled uniformly \\
\hline & 35 & 45 & 25 & 2 & 2 & 44 & 36 & 39 & 31 & 23 & 12 & Farly clean & Pits distribuled unitormly \\
\hline 1 & 46 & 29 & 37 & 26 & 31 & 46 & 51 & 4 & 48 & 33 & 137 & Faurly clean & Pits distıbuted untormly \\
\hline & 8 & 5 & 39 & 31 & 44 & 36 & 25 & 23 & 14 & 13 & 102 & Large corrosion patches & Few pits \\
\hline & 111 & 51 & 69 & 53 & 57 & 38 & 33 & 33 & 3 & 22 & 111 & and of pits around the pipe. chain handing & Localised pits \\
\hline & 101 & 101 & 95 & 58 & 57 & 38 & 28 & 21 & 11 & 27 & 101 & Uniform generalised corrosion & distributed uniformly on $50 \%$ \\
\hline & 43 & 47 & 23 & 51 & 32 & 27 & 43 & 26 & 16 & 13 & 104 & Two ateas of localised contosion $180^{\circ}$ apant & Pils distributed unitormily \\
\hline A & 46 & 34 & 16 & 28 & 29 & 25 & 24 & 19 & 24 & 24 & 10 & Localised collosion & Many pits distributed uniformly \\
\hline A & 2 & 17 & 13 & 13 & 13 & 24 & 29 & 22 & 26 & 18 & 95 & Fauly clean & 50\% Small pits distributed unitoimly \\
\hline & 18 & 28 & 13 & 15 & 08 & 38 & 43 & 37 & 25 & 28 & 125 & One localised corrosion patch & Many small pirs distributed uniformly \\
\hline & 36 & 25 & 28 & 24 & 17 & 58 & 26 & 21 & 2 & 18 & 105 & Few pits & Few pits \\
\hline
\end{tabular}

